FOOTING $\cdot$ IT. IN. FRANCONIA

BRADFORD - TORREY 


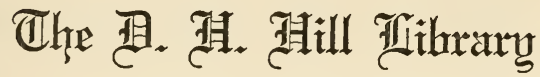

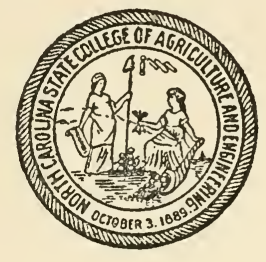

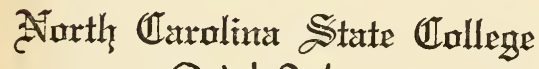

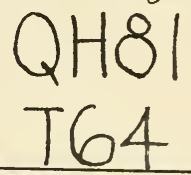

i.

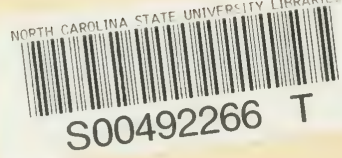


Date Due

7 Nov 3 4

$13 \operatorname{Apr}^{\circ} 51 X$

MAR 13.1963

$\frac{\text { Du } 86.32965}{\text { nc sP } 12.590}$ 

<smiles>[3H]</smiles> 



\section{dỉnots by ftetr. Tarrey.}

EVERYDAY BIRDS. Elementary Studies. With twelve colored Illustrations reproduced from Audubon. Square 12mo, \$r.00.

BIRDS IN THE BUSH. $16 \mathrm{mo}, \$ 1.25$.

A RAMBLER'S LEASE. 16mo, \$1.25. THE FOOT-PATH WAY. $16 \mathrm{mo}$, gilt top, $\$ I .25$.

A FLORIDA SKETCH-BOOK. I6mo, \$1.25. SPRING NOTES FROM TENNESSEE. I6mo, \$1.25.

A WORLD OF GREEN HILLS. I6mo, \$1.25. FOOTING IT IN FRANCONIA. $16 \mathrm{mo}$, \$1.ro, net; postpaid, \$1.20.

HOUGHTON, MIFFLIN \& CO.

Boston ANd New York. 


\section{FOOTING I T I N F R A N CON I A}

BY

\section{BRADFORD TORREY}

"And now each man bestride his hobby, and dust away his bells to what tune he pleases."

Charles Lamb.

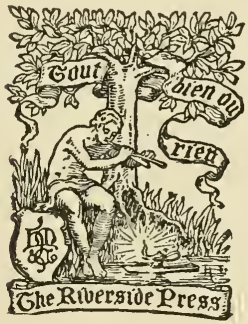

BOSTON AND NEW YYORK HOUGHTON, MIFFLIN AND COMPANY

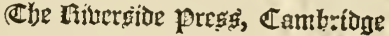


COPYRIGHT, I9OI, BY BRADFORD TORREY ALL RIGHTS RESERVED

Published October, Igor 
CONTENTS.

PAGE

Autumn . . . . . . . . . . . . 1

SPRING . . . . . . . . . . . . 79

A Day in June . . . . . . . . . 120

Berry-Thue Felicities . . . . . . . 147

Red Leaf Days . . . . . . . . . . . 177

American Skylarks . . . . . . . . 195

A Quiet Morning . . . . . . . . . 208

IN the LandafF Valley . . . . . . . . 217

A Visit to Mount Agassiz . . . . . 228

QT 81

$T 64$

4390 


\section{FOOTING IT IN FRANCONIA}

\section{AUTUMN}

"There did they dwell, As happy spirits as were ever seen; If but a bird, to keep them company, Or butterfly sate down, they were, I ween, As pleased as if the same had been a Maiden-queen."

WORDSWORTH.

Five or six hours of pleasant railway travel, up the course of one river valley after another, - the Merrimac, the Pemigewasset, the Baker, the Connecticut, and finally the Ammonoosuc, - not to forget the best hour of all, on the shores of Lake Winnipisaukee, the spacious blue water now lying full in the sun, now half concealed by a fringe of woods, with mountains and hills, Chocorua, Paugus, and the rest, shifting their places beyond it, appearing and disappearing as the train follows the winding track, - five 
or six hours of this delightful panoramic journey, and we leave the cars at Littleton. Then a few miles in a carriage up a long, steep hill through a glorious autumn-scented forest, the horses pausing for breath as one water-bar after another is surmounted, and we are at the height of land, where two or three highland farmers have cleared some rocky acres, built houses and painted them, and planted gardens and orchards. As we reach this happy clearing all the mountains stand facing us on the horizon, and below, between us and Lafayette, lies the valley of Franconia, toward which, again through stretches of forest, we rapidly descend. At the bottom of the way Gale River comes dancing to meet us, babbling among its boulders, - more boulders than water at this end of the summer heats, - in its cheerful uphill progress. Its uphill progress, I say, and repeat it; and if any reader disputes the word, then he has never been there and seen the water for himself, or else he is an unfortunate who has lost his child's heart (without which there is no kingdom of heaven for a man), and no longer lives by faith in 
his own senses. On the spot I have called the attention of many to it, and they have every one agreed with me. Mountain rivers have attributes of their own; or, possibly, the mountains themselves lay some spell upon the running water or upon the beholder's eyesight. Be that as it may, Lafayette all the while draws nearer and nearer, we going one way and Gale River the other, until, after leaving the village houses behind us, we alight almost at its base. Solemn and magnificent, it is yet most companionable, standing thus in front of one's door, the first thing to be looked at in the morning, and the last at night.

The last thing to be thought of at night is the weather, - the weather and what goes with it and depends upon it, the question of the next day's programme. In a hill country meteorological prognostications are proverbially difficult; but we have learned to "hit it right" once in a while; and, right or wrong, we never omit our evening forecast. " It looks like a fair day to-morrow," says one. "Well," answers the other, with no thought of discourtesy in the use of the sub- 
junctive particle, "if it is, what say you to walking to Bethlehem by the way of Wallace Hill, and taking in Mount Agassiz on our return after dinner?" Or the prophet speaks more doubtfully, and the other says, "Oh well, if it is cloudy and threatening, we will go the Landaff Valley round, and see what birds are in the larch swamp. If it seems to have set in for a steady rain, we can try the Butter Hill road."

And so it goes. In Franconia it must be a very bad half day indeed when we fail to stretch our legs with a five or six mile jaunt. I speak of those of us who foot it. The more ease-loving, or less uneasy members of the party, who keep their carriage, are naturally less independent of outside conditions. When it rains they amuse themselves indoors; a pitch of sensibleness which the rest of us may sometimes regard with a shade of envy, perhaps, though we have never admitted as much to each other, much less to any one else. To plod through the mud is more exhilarating than to sit before a fire; and we leave the question of reasonableness and animal comfort on one side. Time is short, 
and we decline to waste it on theoretical considerations.

Our company, as I say, is divided: carriage people and pedestrians, we may call them; or, if you like, drivers and footmen. The walkers are now no more than the others. Formerly - till this present autumn - they were three. Now, alas, one of them walks no longer on earth. The hills that knew him so well know him no more. The asters and goldenrods bloom, but he comes not to gather them. The maples redden, but he comes not to see them. Yet in a better and truer sense he is with us still; for we remember him, and continually talk of him. If we pass a sphagnum bog, we think how at this point he used to turn aside and put a few mosses into his box. Some professor in Germany, or a scholar in New Haven, had asked him to collect additional specimens. In those days of his sphagnum absorption we called him sometimes the "sphagnostic."

If we come down a certain steep pitch in the road from Garnet Hill, we remind each other that here he always stopped to look for Aster Lindleyanus, telling us meanwhile 
how problematical the identity of the plant really was. Professor So-and-So had pronounced it Lindleyanus, but Doctor Somebody-Else believed it to be only an odd form of a commoner species. In the Wallace Hill woods, I remember how we spent an afternoon there, he and I, only two years ago, searching for an orchid which just then had come newly under discussion among botanists, and how pleased he was when for once my eyes were luckier than his. If we are on the Landaff road, my companion asks, "Do you remember the Sunday noon when we went home and told E_- that this wood was full of his rare willow? And how he posted over here by himself, directly after dinner, to see it? And how he said, in a tone of whimsical entreaty, 'Please don't find it anywhere else; we must n't let it become too common'?" Oh yes, I remember ; and my companion knows he has no need to remind me of it; but he loves to talk of the absent, - and he knows I love to hear him.

That willow I can never see anywhere without thinking of the man who first told me about it. Whether I pass the single 
small specimen between Franconia and the Profile House, so close upon the highway that the road-menders are continually cutting it back, or the one on the Bethlehem road, or the great cluster of stems on Wallace Hill, it will always be his willow.

And indeed this whole beautiful hill country is his. How happy he was in it! I used sometimes to talk to him about the glories of our Southern mountains, - Tennessee, North Carolina, Virginia; but he was never to be enticed away even in thought. "I think I shall never go out of New England again," he would answer, with a smile ; and he never did, though in his youth he had traveled more widely than I am ever likely to do. The very roadsides here must miss him, and wonder why he no longer passes, with his botanical box slung over his shoulder and an opera-glass in his hand, - equally ready for a plant or a bird. He was always looking for something, and always finding it. With his happiness, his goodness, his gentle dignity, his philosophic temper, his knowledge of his own mind, his love of all things beautiful, he has made Franconia a dear place for all of us who knew him here. 
To me, as to all of us, it is dear also for its own sake. This season I returned to it alone, - with no walking mate, I mean to say. He was to join me later, but for eight or ten days I was to follow the road by myself. At night I must make my own forecast of the weather and lay out my own morrow.

The first day was one of the good ones, fair and still. As I came out upon the piazza before breakfast and looked up at Lafayette, a solitary vireo was phrasing sweetly from the bushes on one side of the house, and two or three vesper sparrows were remembering the summer from the open fields on the other side. It was the $22 \mathrm{~d}$ of September, and by this time the birds knew how to appreciate a day of brightness and warmth.

Seeing them in such a mood, I determined to spend the forenoon in their society. I would take the road to Sinclair's Mills, - a woodsy jaunt, yet not too much in the forest, always birdy from one end to the other.

"This is living!" I found myself repeating aloud, as I went up the longish hill to the plateau above Gale River, on the Beth- 
lehem road. "This is living!" No more books, no more manuscripts, - my own or other people's, — no more errands to the city. How good the air was! How glorious the mountains, unclouded, but hazy! How fragrant the ripening herbage in the shelter of the woods! - an odor caught for an instant, and then gone again; something that came of itself, not to be detected, much less traced to its source, by any effort or waiting. The forests were still green, - I had to look elosely to find here and there the first touch of red or yellow; but the flowering season was mostly over, a few ragged asters and goldenrods being the chief brighteners of the wayside. About the sunnier patches of them, about the asters especially, insects were hovering, still drinking honey before it should be too late: yellow butterflies, bumble-bees (of some northern kind, apparently, marked with orange, and not so large as our common Massachusetts fellow), with swarms of smaller creatures of many sorts. If I stopped to attend to it, each aster bunch was a world by itself. And more than once I did stop. There was no 
haste; I had chosen my route partly with a view to just such idling; and the birds were, and were likely to be, nothing but old favorites. And they proved to be not many, after all. The best of them were the winter wrens, which I thought I had never seen more numerous; every one fretting, tut, tut, in their characteristic manner, without a note of song.

On my way back, the sun being higher, there were many butterflies in the road, flat on the sand, with wings outspread. If ever there is comfort in the world, the butterfly feels it at such times. Here and there half a dozen or more of yellow ones would be huddled about a damp spot. There were mourning-cloaks, also, and many small angle-wings, some species of Grapta, I knew not which, of a peculiarly bright red. Once or twice, wishing a name for them, I essayed to catch a specimen under my hat; but it seemed a small business, at which I was only half ashamed to find myself grown inexpert.

The forenoon was not without its tragedy, nevertheless. As I came out into the open, on my return from the river woods toward 
the Bethlehem road, a carriage stopped across the field; a man jumped out, gun in hand, ran up to an unoccupied house standing there by itself, with a tract of low meadow behind it, peeped cautiously round the corner, lifted his gun, leveled it upon something with the quickness of a practiced marksman, and fired. Then down the grassy slope he went on the run out of sight, and in a minute reappeared, holding a crow by its claw. He took the trophy into the carriage with him, - two ladies and a second man occupying the other seats, - and as I emerged from the pine wood, fifteen minutes afterward, I found it lying in the middle of the road. Its shining feathers would fly no more; but its death had brightened the day of some of the lords and ladies of creation. What happier fate could a crow ask for?

One of my first desires, this time (there is always something in particular on my mind when I go to Franconia), was to revisit Lonesome Lake, a romantic sheet of water lying deep in the wilderness on the back side of Mount Cannon, at an elevation of perhaps twenty-eight hundred feet, or 
something less than a thousand feet above the level of Profile Notch. One of its two owners, fortunately, is of our Franconia company; and when I spoke of myintention of visiting it again, he bade me drive up with his man, who would be going that way within a day or two. Late as the season was getting, he still went up to the lake once or twice a week, it appeared, keeping watch over the cabin, boat-house, and so forth. The plan suited my convenience perfectly. We drove to the foot of the bridle path, off the Notch road; the man put a saddle on the horse and rode up, and I followed on foot.

The climb is longer or shorter, as the climber may elect. A pedestrian would do it in thirty minutes, or a little less, I suppose; a nature-loving stroller may profitably be two hours about it. There must be at least a hundred trees along the path, which a sensitive man might be glad to stop and commune with: ancient birches, beeches, and spruces, any one of which, if it could talk, or rather if we had ears to hear it, would tell us things not to be read in any book. Hundreds of years many of the 
spruces must have stood there. Some of them, in all likelihood, were of a good height long before any white man set foot on this continent. Many of them were already old before they ever saw a paleface. What dwarfs and weaklings these restless creatures are, that once in a while come puffing up the hillside, halting every few minutes to get their breath and stare foolishly about! What murderer's curse is on them, that they have no home, no abiding-place, where they can stay and get their growth?

It is a precious and solemn stillness that falls upon a man in these lofty woods. Across the narrow pass, as he looks through the branches, are the long, rugged upper slopes of Lafayette, torn with slides and gashed into deep ravines. Far over his head soar the trees, tall, branchless trunks pushing upward and upward, seeking the sun. In their leafy tops the wind murmurs, and here and there a bird is stirring. Now a chickadee lisps, or a nuthatch calls to his fellow. Out of the tangled, round-leaved hobble-bushes underneath an occasional robin may start with a quick note of surprise, or a 
flock of white-throats or snowbirds will fly up one by one to gaze at the intruder. In one place I hear the faint smooth-voiced signals of a group of Swainson thrushes and the chuck of a hermit. A few siskins (rarer than usual this year, it seems to me) pass overhead, sounding their curious, long-drawn whistle, as if they were blowing through a fine-toothed comb. Further up, I stand still at the tapping of a woodpecker just before me. Yes, there he is, on a dead spruce. A sapsucker, I call him at the first glance. But I raise my glass. No, it is not a sapsucker, but a bird of one of the three-toed species; a male, for I see his yellow crown-patch. His back is black. And now, of a sudden, a second one joins him. I am in great luck. This is a bird I have never seen before except once, and that many years ago on Mount Washington, in Tuckerman's Ravine. The pair are gone too soon, and, patiently as I linger about the spot, I see no more of them. A pity they could not have broken silence. It is little we know of a bird or of a man till we hear him speak.

At the lake there are certain to be num. 
bers of birds; not water birds, for the most part, — though I steal forward quietly at the last, hoping to surprise a duck or two, or a few sandpipers, as sometimes I have done, but birds of the woods. The water makes a break in the wilderness, - a natural rendezvous, as we may say; it lets in the sun, also, and attracts insects; and birds of many kinds seem to enjoy its neighborhood. I do not wonder. To-day I notice first a large flock of white-throats, and a smaller flock of cedar-birds. The latter, when I first discover them, are in the conical tops of the tall spruces, whence they rise into the air, one after another, with a peculiar motion, as if a hand had tossed them aloft. They are catching insects, a business at which no bird can be more graceful, I think, though some may have been at it longer and more exclusively. Their behavior is suggestive of play rather than of a serious occupation. Near the white-throats are snowbirds, and in the firs by the lakeside chickadees are stirring, among which, to my great satisfaction, I presently hear a few Hudsonian voices. Sicka-day-day, they call, and soon a little brown- 
headed fellow is directly at my elbow. I stretch out my hand, and chirp encouragingly. He comes within three or four feet of it, and looks and looks at me, but is not to be coaxed nearer. Sick-a-day-day-day, he calls again ("I don't like strangers," he means to tell me), and away he flits. He is almost always here, and right glad I am to see him on my annual visit. I have never been favored with a sight of him further south.

The lake is like a mirror, and $\mathrm{I}$ sit in the boat with the sun on my back (as comfortable as a butterfly), listening and looking. What else can I do? I have pulled out far enough to bring the top of Lafayette into view above the trees, and have put down the oars. The birds are mostly invisible. Chickadees can be heard talking among themselves, a flicker calls wicker, wicker, whatever that means, and once a kingfisher springs his rattle. Red squirrels seem to be ubiquitous, full of sauciness and chatter. How very often their clocks need winding! A few big dragon-flies are still shooting over the water. But the best thing 
of all is the place itself : the solitude, the brooding sky (the lake's own, it seems to be), the solemn mountain top, the encircling forest, the musical woodsy stillness. The rowan trees were never so bright with berries. Here and there one still holds full of green leaves, with the ripe red clusters shining everywhere among them.

After luncheon I must sit for a while in the forest itself. Every breath in the treetops, unfelt at my level, brings down a sprinkling of yellow birch leaves, each with a faint rustle, like a whispered good-by, as it strikes against the twigs in its fall. Every one preaches its sermon, and I know the text, - "We all do fade." May the rest of us be as happy as the leaves, and fade only when the time is ripe. A nuthatch, busy with his day's work, passes near me. Small as he is, I hear his wing-beats. A squirrel jumps upon the very log on which I am seated, but is off in a jiffy on catching: sight of so unexpected a neighbor. So short a $\log$ is not big enough for two of us, he thinks. By and by I hear a bird stirring on a branch overhead, and look up to find 
him a red-eyed vireo. One of the belated, he must be, according to my almanac. $\mathrm{He}$ peers down at me with inquisitive, sidelong glances. A man! - in such a place!and sitting still! I like to believe that he, as well as I, feels a pleasurable surprise at the unlooked-for encounter. We call him the preacher, but he is not sermonizing today, perhaps because the falling leaves have taken the words out of his mouth.

It is one of the best things about a place like this that it gives a man a most unusual feeling of remoteness and isolation. To be here is not the same as to be in some equally wild and silent spot nearer to human habitations. The sense of the climb we have made, of the wilderness we have traversed, still folds us about. The fever and the fret, so constant with us as to be mostly unrealized or taken for the normal state of man, are for the moment gone, and peace settles upon the heart. For myself, at least, there is an unspeakable sweetness in such an hour. I could stay here, forever, I think, till I became a tree. That feeling I have often had, - a state of ravishment, a kind of absorp- 
tion into the life of things about me. It will not last, and I know it will not; but it is like heaven, for the time it is on me, - a foretaste, perhaps, of the true Nirvana.

Yet to-day - so self-contradictory a creature is man - there were some things I missed. The dreamer was still a hobbyist, and the hobbyist had been in the Lonesome Lake woods before; and he wondered what had become of the crossbills. The common red ones were always here, I should have said, and on more than one visit I had found the rarer and lovelier white-winged species. Now, in all the forest chorus, not a crossbill's note was audible.

One day, bright like this, I was sitting at luncheon on the sunny stoop of the cabin, facing the water, when I caught a sudden glimpse of a white-wing, as I felt sure, about some small decaying gray logs on the edge of the lake just before me, the remains of a disused landing. The next moment the bird dropped out of sight between two of them. I sat motionless, glass in hand, and eyes fixed (so I could almost have made oath) upon the spot where he had disappeared. I 
fancied he was at his bath. Minute after minute elapsed. There was no sign of him, and at last I left my seat and made my way stealthily down to the shore. Nothing rose. I tramped over the logs, with no result. It was like magic, - the work of some evil spirit. I began almost to believe that my eyes had been made the fools of the other senses. If I had seen a bird there, where in the name of reason could it have gone? It could not have dropped into the water, seeking winter quarters in the mud at the bottom, according to the notions of our oldtime ornithologists !

Half an hour afterward, having finished my luncheon, I went into the woods along the path; and there, presently, I discovered a mixed flock of crossbills, - red ones and white-wings, - feeding so quietly that till now I had not suspected their presence. My waterside bird was doubtless among them; and doubtless my eyes had not been fixed upon the place of his disappearance quite so uninterruptedly as I had imagined. It was not the first time that such a thing had happened to me. How frequently have 
we all seen a bird dart into a bit of cover, and never come out! If we are watchful and clever, we are not the only ones.

Luck has no little to do with a bird-lover's success or failure in any particular walk. If we go and go, patience will have its wages; but if we can go but once or twice, we must take what Fortune sends, be it little or much. So it had been with me and the three-toed woodpeckers, that morning. I had chanced to arrive at that precise point in the path just at the moment when they chanced to alight upon that dead spruce, one tree among a million. What had been there ten minutes before, and what came ten minutes after, I shall never know. So it was again on the descent, which I protracted as much as possible, for love of the woods and for the hope of what I might find in them. I was perhaps halfway down when I heard thrush calls near by: the whistle of an olive-back and the chuck of a hermit, both strongly characteristic, slight as they seem. I halted, of course, and on the instant some large bird flew past me and perched in full sight, only a few rods away. 
There he sat facing me, a barred owl, his black eyes staring straight into mine. How big and solemn they looked! Never tell me that the barred owl cannot see by daylight.

The thrushes had followed him. It was he, and not a human intruder, to whom they had been addressing themselves. Soon the owl flew a little further away (it was wonderful how large he looked in the air), the thrushes still after him; and in a few minutes more he took wing again. This time several robins joined the hermit and the olive-back, and all hands disappeared up the mountain side. Probably the pursuers were largely reinforced as the chase proceeded, and I imagined the big fellow pretty thoroughly mobbed before he got safely away. Every small bird has his opinion of an owl.

What interested me as much as anything connected with the whole affair was the fact that the olive-back, even in his excitement, made use of nothing but his mellow staccato whistle, such as he employs against the most inoffensive of chance human disturbers. Like the chickadee, and perhaps some other birds, he is musical, and not over-emphatic, even in his anger. 
Again and again I rested to admire the glory of Mount Lafayette, which loomed more grandly than ever, I was ready to declare, seen thus partially and from this point of vantage. Twice, at least, I had been on its summit in such a fall day, - once on the 1st of October, and again, the year afterward, on a date two days earlier. That October day was one of the fairest I ever knew, both in itself (and perfect weather is a rare thing, try as we may to speak nothing but good of the doings of Providence) and in the pleasure it brought me.

For the next year's ascent, which I remember more in detail, we chose - a brother Franconian and myself - a morning when the tops of the mountains, as seen from the valley lands, were white with frost or snow. We wished to find out for ourselves which it was, and just how the mountain looked under such wintry conditions.

The spectacle would have repaid us for a harder climb. A cold northwest wind (it was still blowing) had swept over the summit and coated everything it struck, foliage and rocks alike, with a thick frost (half an 
inch or more in depth, if my memory is to be trusted), white as snow, but almost as hard as ice. The effect was strangely beautiful. A dwarf fir tree, for instance, would be snow white on one side and bright green on the other. As we looked along the sharp ridge running to the South Peak, so called (the very ridge at the face of which $I$ was now gazing from the Lonesome Lake path), one slope was white, the other green. Summer and winter were divided by an inch.

We nestled in the shelter of the rocks, on the south side of the summit, courting the sun and avoiding the wind, and lay there for two hours, exulting in the prospect, and between times nibbling our luncheon, which latter we "topped off" with a famous dessert of berries, gathered on the spot: three sorts of blueberries, and, for a sour, the mountain cranberry. The blueberries were Vaccinium uliginosum, $V$. ccespitosum, and $V$. Pennsylvanicum (there is no doing without the Latin names), their comparative abundance being in the order given. The first two were really plentiful. All of them, of course, grew on dwarf bushes, matting the 
ground between the boulders. At that exposed height not even a blueberry bush ventures to stand upright. One of them, V. crspitosum, was both a surprise and a luxury, the small berries having a most deliciously rich fruity flavor, like the choicest of bananas! Probably no botanical writer has ever mentioned the point, and I have great satisfaction in supplying the deficiency, apprehending no rush of epicures to the place in consequence. About the fact itself there can be no manner of doubt. My companion fully agreed with me, and he is not only a botanist of international repute, but a most capable gastronomer. Much the poorest berry of the three was the Pennsylvanian, the common low blueberry of Massachusetts. "Strawberry huckleberry" it used to be called in my day by Old Colony children, with a double disregard of scientific proprieties. Even thus late in the season the Greenland sandwort was in perfectly fresh bloom; but the high cold wind made it a poor " bird day," though I remember a white-throated sparrow singing cheerily near Eagle Lake, and a large hawk or eagle floating high over 
the summit. At the sight my fellow traveler broke out, -

"My heart leaps up when I behold An eagle in the sky."

On that point, as concerning the fine qualities of the cespitose blueberry, we were fully agreed.

Even in Franconia, however, most of our days are spent, not in mountain paths, but in the valley and lower hill roads. We keep out of the mountains partly because we love to look at them ("I pitch my walk low, but my prospects high," says an old poet), and partly, perhaps, because the paths to their summits have seemed to fall out of repair, and even to become steeper, with the lapse of years. One of my good trips, this autumn, was over the road toward Littleton, and then back in the direction of Bethlehem as far as the end of the Indian Brook road. That, as I planned it, would be no more than six or seven miles, at the most, and there I was to be met by the driving members of the club, who would bring me home for the midday meal, - an altogether comfortable arrangement. It is good to have time to spare, 
so that one can dally along, fearful only of arriving at the end of the way too soon. Such was now my favored condition, and I made the most of it. If I crossed a brook, I stayed awhile to listen to it and moralize its song. If a flock of bluebirds and sparrows were twittering about a farmer's barn, I lingered a little to watch their doings. When a white-crowned sparrow or a partridge showed itself in the road in advance of me, that was reason enough for another halt. It is a pretty picture : a partridge caught unexpectedly in the open, its ruff erect, and its tail, fully spread, snapping nervously with every quick, furtive step. And the fine old trees in the Littleton hill woods were of themselves sufficient, on a warm day like this, to detain any one who was neither a worldling nor a man sent for the doctor. They detained me, at all events; and very glad I was to sit down more than once for a good season with them.

And so the hours passed. At the top of the road, in the clearing by the farms, I met a pale, straight-backed young fellow under a military hat. "You look like a man 
from Cuba or from Chickamauga," I ventured to say. "Chickamauga," he answered laconically, and marched on. Whether it was typhoid fever or simple " malaria" that had whitened his face there was no chance to inquire. He was munching an apple, which at that moment was also my own occupation. I had just stopped under a promising-looking tree, whose generous branches spilled their crop over the roadside wall, - excellent "common fruit," as Franconians say, mellow, but with a lively, ungrafted tang. Here in this sumny stretch of road were more of my small Grapta butterflies, and presently I came upon a splendid tortoise-shell ( $V a$ nessa Milberti). That I would certainly have captured had I been armed with a net. I had seen two like it the day before, to the surprise of my friends the carriage people, ardent entomological collectors, both of them. They had found not a single specimen the whole season through. "There are some advantages in beating out the miles on foot," I said to myself. I have never seen this strikingly handsome butterfly in Massachusetts, as I once did its rival in beauty, 
the banded purple (Arthemis); and even here in the hill country it is never so common as to lose that precious bloom which rarity puts upon whatever it touches.

As I turned down the Bethlehem road, the valley and hill prospects on the left became increasingly beautiful. Here I passed hermit thrushes (it was good to see them already so numerous again, after the destruction that had wasted them a few winters ago), a catbird or two, and a few rubycrowned kinglets, - some of them singing, - and before long found myself within the limits of a rich man's red farm; fences, houses, barns, poultry coops, and the rest, all painted of the same deep color, as if to say, "All this is mine." I remembered the estate well, and have never grudged the owner of it his lordly possessions. I enjoy them, also, in my own way. He keeps his roads in apple-pie order, without meddling with their natural beauty (I wish our Massachusetts " highway surveyors" all worked under his orders, or were endowed with his taste), and is at pains to save his woods from the hands of the spoiler. "Please do not 
peel bark from the birch trees," - so the signs read; and I say Amen. He has splendid flower gardens, too, and plants them well out upon the wayside for all men to enjoy. Long may it be before his soul is required of him.

By this time $I$ was in the very prettiest of the red-farm woods. Hermit thrushes were there, also, standing upright in the middle of the road, and in the forest hylas were peeping, one of them a real champion for the loudness of his tone. How full of glory the place was, with the sunlight sifting through the bright leaves and flickering upon the shining birch trunks! If I were an artist, I think I would paint wood interiors.

My forenoon's walk was ended. Another turn in the road, and I saw the carriage before me, the driver minding the horses, and the passengers' seat vacant. The entomologists had gone into the woods looking for specimens, and there I joined them. They were in search of beetles, they said, and had no objection to my assistance; I had better look for decaying toadstools. This was easy 
work, I thought; but, as is always the way with my efforts at insect collecting, I could find nothing to the purpose. The best I could do was to bring mushrooms full of maggots (larvæ, the carrier of the cyanide and alcohol bottles called them), and what was desired was the beetles which the larvæ turned into. Once I announced a small spider, but the bottle-holder said, No, it was not a spider, but a mite; and there was no disputing an expert, who had published a list of Franconia spiders, - one hundred and forty-nine species! (She had wished very much for one more name, she told me, but her friend and assistant had remarked that the odd number would look more honest!) However, it is a poor sort of man who cannot enjoy the sight of another's learning, and the exposure of his own ignorance. It was worth something to see a first-rate, thoroughly equipped "insectarian" at work and to hear her talk. I should have been proud even to hold one of her smaller phials, but they were all adjusted beyond the need, or even the comfortable possibility, of such assistance. There was 
nothing for it but to play the looker-on and listener. In that part I hope I was less of a failure.

The enthusiastic pursuit of special knowledge, persisted in year after year, is a phenomenon as well worth study as the song and nesting habits of a thrush or a sparrow; and I gladly put myself to school, not only this forenoon, but as often as I found the opportunity. One day my mentor told me that she hoped she had discoverd a new flea! She kept, as I knew, a couple of pet deer-mice, and it seemed that some almost microscopic fleas had left them for a bunch of cotton wherein the mice were accustomed to roll themselves up in the daytime. These minute creatures the entomologist had pounced upon, clapped into a bottle, and sent off straightway to the American flea specialist, who lived somewhere in Alabama. In a few days she should hear fronr him, and perhaps, if the species were undescribed, there would be a flea named in her honor. ${ }^{1}$

1 The species was not new. A Maine collector had anticipated her, I believe. Whether his name was given to the flea I did not learn or have forgotten. 
Distinctions of that nature are almost every-day matters with her. How many species already bear her name she has never told me. I suspect they are so numerous and so frequent that she herself can hardly keep track of them. Think of the pleasure of walking about the earth and being able to say, as an insect chirps, "Listen! that is one of my species, - named after me, you know." Such specific honors, I say, are common in her case, - common almost to satiety. But to have a genus named for her, - that was glory of a different rank, glory that can never fall to the same person but once; for generic names are unique. Once given, they are patented, as it were. They can never be used again - for genera, that is - in any branch of natural science. To our Franconia entomologist this honor came, by what seemed a poetic justice, in the Lepidoptera, the order in which she began her researches. Hers is a genus of moths. I trust they are not of the kind that "corrupt."

Thinking how above measure I should be exalted in such circumstances, I am surprised 
that she wears her laurels so meekly. Not that she affects to conceal her gratification; she is as happy over her genus, perhaps, as over the new édition de luxe of her most famous story; for an entomologist may be also a novelist, if she has a mind to be, as Charles Lamb would have said; but she knows how to carry it off lightly. She and the botanist of the party, my "walking mate," who, I am proud to say, is similarly distinguished, often laugh together about their generic namesakes (his is of the large and noble Compositre family); and then, sometimes, the lady will turn to me.

"It is too bad you can never have a genus," she will say in her bantering tone; " the name is already taken up, you know."

"Yes, indeed, I lnnow it," I answer her. An older member of the family, a - th cousin, carried off the prize many years ago, and the rest of us are left to get on as best we can, without the hope of such dignities. When I was in Florida I took pains to see the tree, - the family evergreen, we may call it. Though it is said to have an ill smell, it is handsome, and we count it an honor. 
"But then, perhaps you would never have had a genus named for you, anyhow," the entomologist continues, still bent upon mischief.

And there we leave the matter. Let the shoemaker stick to his last. Some of us were not born to shine at badinage, or as collectors of beetles. For myself, in this bright September weather I have no ambitions. It is enough, I think, to be a follower of the road, breathing the breath of life and seeing the beauty of the world.

In the afternoon I took the Landaff Valley round, down the village street nearly to the junction of Gale River and Ham Branch, then up the Ham Branch (or Landaff) Valley to a crossroad on the left, and so back to the road from the Profile Notch, and by that home again. The jaunt, which is one of our Franconia favorites, is peculiar for being substantially level; with no more uphill and downhill than would be included in a walk of the same distance - perhaps six miles - almost anywhere in southern New England. 
The first thing a man is likely to notice as he passes the last of the village houses, and finds himself skirting the bank of Ham Branch (which looks to be nearly or quite as full as the river into which it empties itself), is the color of the water. Gale River is fresh from the hills, and ripples over its stony bed as clear as crystal. The branch, on the contrary, has been flowing for some time through a flat meadowy valley, where it has taken on a rich earthy hue, to which it might be natural to apply a less honorable sounding word, perhaps, if it were a question of some neutral stream, in whose character and reputation I felt no personal, friendly interest.

Just as I came to it, that afternoon, I saw to my surprise a white admiral butterfly sunning itself upon an alder leaf. I hope the reader knows the species, - Limenitis Arthemis, sometimes called the banded purple, - one of the prettiest and showiest of New England insects, four black or blackish wings crossed by a broad white band. It was much out of season now, I felt sure, both from what my entomological friends 
had told me, and from my own recollections of previous years, and I was seized with a foolish desire to capture it as a sort of trophy. It lay just beyond my reach, and I disturbed it, in hopes it would settle nearer the ground. Twice it disappointed me. Then I threw a stick toward it, aiming not wisely but too well, and this time startled it so badly that it rose straight into the air, sailed across the stream, and came to rest far up in a tall elm. "You were never cut out for a collector of insects," I said to myself, recalling my experience of the forenoon; but I was glad to have seen the creature, the first one for several years, - and went on my way as happy as a child in thinking of it. In the second half of a man's century he may be thankful for almost anything that, for the time being, lifts twoscore of years off his back. The best part of most of us, I think, is the boy that was born with us. So far I am a Wordsworthian;-

"And I could wish my days to be Bound each to each by natural piety."

A little way up the valley we come to an ancient mill and a bridge; a new bridge it 
is now, but I remember an old one, and a fright that I once had upon it. With a fellow itinerant - a learned man, whose life was valuable - I stopped here to rest of a summer noon, and my companion, with an eye to shady comfort, clambered over the edge of the bridge and out upon a joist which projected over the stream. There he sat down with his back against a pillar and his legs stretched before him on the joist. He has a theory, concerning which I have heard him discourse more than once, something in his own attitude suggesting the theme, - that when a man, after walking, "puts his feet up," he is acting not merely upon a natural impulse, but in accordance with a sound physiological principle; and in accordance with that principle he was acting now, as well as the circumstances of the case would permit. We chatted awhile; then he fell silent; and after a time I turned my head, and saw him clean gone in a doze. The seat was barely wide enough to hold him. What if he should move in his sleep, or start up suddenly on being awakened? I looked at the 
rocks below, and shivered. I dared not disturb him, and could only sit in a kind of stupid terror and wait for him to open his eyes. Happily his nap did not last long, and came to a quiet termination; so that the cause of science suffered no loss that day; but I can never go by the place without thinking of what might have happened.

Here, likewise, on an autumnal forenoon, two or three years ago, I had another memorable experience; nothing less (nothing more, the reader may say) than the song of a hermit thrush. It was in the season after bluebirds and hermits had been killed in such dreadful numbers (almost exterminated, we thought then) by cold and snow at the South. I had scarcely seen a hermit all the year, and was approaching the bridge, of a pleasant late September morning, when I heard a thrush's voice. I stopped instantly. The note was repeated; and there the bird stood in a low roadside tree; the next minute he began singing in a kind of reminiscential half-voice, - the soul of a year's music distilled in a few drops of sound, such as birds of many kinds so frequently 
drop into in the fall. That, too, I am sure to remember as often as I pass this way.

In truth, all my Franconia rambles ( $\mathrm{I}$ am tempted to write the name in three syllables. as I sometimes speak it, following the example of Fishin' Jimmy and other local worthies), - all my "Francony" rambles, I say, are by this time full of these miserly delights. It is really a gain, perhaps, that I make the round of them but once a year. Some things are wisely kept choice.

"Therefore are feasts so solemn and so rare."

To get all the goodness out of a piece of country, return to it again and again, till every corner of it is alive with memories; but do not see it too often, nor make your stay in it too long. The hermit thrush's voice is all the sweeter because he is a hermit.

This afternoon I do not cross the bridge, but keep to the valley road, which soon runs for some distance along the edge of a hackmatack swamp; full of graceful, penciltipped, feathery trees, with here and there a dead one, on purpose for woodpeckers and 
hawks. A hairy woodpecker is on one of them at this moment, now hammering the trunk with his powerful beak (hammer and chisel in one), now lifting up his voice in a way to be heard for half a mile. To judge from his ordinary tone and manner, Dryobates villosus has no need to cultivate decision of character. Every word is peremptory, and every action speaks of energy and a mind made up.

In this larch swamp, though I have never really explored it, I have seen, first and last, a good many things. Here grows much of the pear-leaved willow (Salix balsamifera). I notice a few bushes even now as I pass, the reddish twigs each with a tuft of yellowing, red-stemmed leaves at the tip. Here, one June, a Tennessee warbler sang to me; and there are only two other places in the world in which I have been thus favored. Here, - a little farther up the valley, — on a rainy September forenoon, I once sat for an hour in the midst of as pretty a flock of birds as a man could wish to see: south-going travelers of many sorts, whom the fortunes of the road had thrown together. 
Here they were, lying by for a day's rest in this favorable spot; flitting to and fro, chirping, singing, feeding, playfully quarreling, as if life, even in rainy weather and in migration time, were all a pleasure trip. It was a sight to cure low spirits. I sat on the hay just within the open side of a barn which stands here in the woods, quite by itself, and watched them till I almost feit myself of their company. I have forgotten their names, though I listed them carefully enough, beyond a doubt; but it will be long before I forget my delight in the birds themselves. Ours may be an evil world, as the pessimists and the preachers find so much comfort in maintaining, but there is one thing to be said in its favor: its happy days are the longest remembered. The pain I suffered years ago I cannot any longer make real to myself, even if I would, but the joys of that time are still almost as good as new, when occasion calls them up. Some of them, indeed, seem to have sweetened with age. This is especially the case, I think, with simple and natural pleasures; which may be considered as a good reason why every man 
should be, if he can, a lover of nature, - a sympathizer, that is to say, with the life of the world about him. The less artificial our joys, the more likelihood of their staying by us.

Not to blink at the truth, nevertheless, I must add a circumstance which, till this moment, I had clean forgotten. I was still watching the birds, with perhaps a dozen species in sight close at hand, when suddenly I observed a something come over them, and on the instant a large hawk skimmed the tops of the trees. In one second every bird was gone, - vanished, as if at the touch of a necromancer's wand. I did not see them fly; there was no rush of wings; but the place was empty; and though I waited for them, they did not reappear. Two or three, indeed, I may have seen afterward, but the flock was gone. $M y$ holiday, at all events, or that part of it, was done, — shadowed by a hawk's wing. Undoubtedly a few minutes of safety put the birds all in comfortable spirits again, however ; and anyhow, it bears out my theory of remembered happiness, that this less cheerful part of the story had so 
completely passed out of mind. Memory, like a sundial, had marked only the bright hour.

Beyond this lonely barn the soil of the valley becomes drier and sandier. Here are two or three houses, with broad hayfields about them, in which live many vesper sparrows. No doubt they have lived here longer than any of their present human neighbors. Even now they flit along the wayside in advance of the foot-passenger, running a space, after their manner, and anon taking wing to alight upon a fence rail. Their year is done, but they linger still a few days, out of love for the ancestral fields, or, it may be, in dread of the long journey, from which some of them will pretty certainly never come back.

All the way up the road, though no mention has been made of it, my eyes have been upon the low, bright-colored hills beyond the river, - sugar-maple orchards all in yellow and red, a gorgeous display, - or upon the mountains in front, Kinsman and the more distant Moosilauke. The green meadow is a good place in which to look for marsh 
hawks, - as well as of great use as a foreground, - and the hill woods beyond are the resort of pileated woodpeckers. I have often seen and heard them here, but there is no sign of them to-day.

Though these fine birds are generally described - one book following another, after the usual fashion - as frequenters of the wilderness, and though it is true that they have forsaken the more thickly settled parts of the country, I think I have never once seen them in the depths of the forest. To the best of my recollection none of our Franconia men have ever reported them from Mount Lafayette or from the Lonesome Lake region. On the other hand, we meet them with greater or less regularity in the more open valley woods, often directly upon the roadside; not only in the Landaff Valley, but on the outskirts of the village toward Littleton and on the Bethlehem road. In this latter place I remember seeing a fellow prancing about the trunk of a small orchard tree within twenty rods of a house; and not so very infrequently, especially in the rumcherry season, they make their appearance 
in the immediate vicinity of the hotel; for they, like some of their relatives, notably the sapsucker, are true cherry-birds. In Vermont, too, I have found their freshly cut "peck-holes" on the very skirts of the village. And at the South, so far as I have been able to observe, the story is the same. About Natural Bridge, Virginia, for example, a loosely settled country, with plenty of woodland but no extensive forests, the birds were constantly in evidence. In short, untamable as they look, and little as they may like a town, they seem to find themselves best off, as birds in general do, on the border's of civilization. They have something of Thoreau's mind, we may say: lovers of the wild, they are yet not quite at home in the wilderness, and prefer the woodman's path to the logger's.

Not far ahead, on the other side of the way, - to return to the Landaff Valley, is a red maple grove, more brilliant even than the sugar orchards. It ripens its leaves earlier than they, as we have always noticed, and is already past the acme of its annual splendor; so that some of the trees have a 
peculiarly delicate and lovely purplish tint, a real bloom, never seen, I think, except on the red maple, and there only after the leaves have begun to curl and fade. Opposite it (after whistling in vain for a dog with whom in years past, I have been accustomed to be friendly at one of the houses - he must be dead, or gone, or grown reserved with age), I take the crossroad before mentioned; and now, face to face with Lafayette, I stop under a favorite pine tree to enjoy the prospect and the stillness: no sound but the chirping of crickets, the peeping of hylas, and the hardly less musical hammering of a distant carpenter.

Along the wayside are many gray birches (of the kind called white birches in Massachusetts, the kind from which Yankee schoolboys snatch a fearful joy by "swinging off" their tops), the only ones I remember about Franconia; for which reason I sometimes call the road Gray Birch Road; and just beyond them I stop again. Here is a bit for a painter : a lovely vista, such as makes a man wish for a brush and the skill to use it. The road dips into a little hollow, turns 
gently, and passes out of sight within the shadow of a wood. And above the overarching trees rises the pyramidal mass of Mount Cannon, its middle part set with dark evergreens, which are flanked on either side with broad patches of light yellow, - poplars or birches. The sun is getting down, and its level rays flood the whole mountain forest with light.

Into the shadow I go, following the road, and after a turn or two come out at a small clearing and a house. "Rocky Farm," we might name it; for the land is sprinkled over with huge boulders, as if giants had been at play here. Whoever settled the place first must have chosen the site for its outlook rather than for any hope of its fertility. I sit down on one of the stones and take my fill of the mountain glory : Garfield, Lafayette, Cannon, Kinsman, Moosilauke, a grand horizonful. Cannon is almost within reach of the hand, as it looks; but the arm might need to be two miles long.

Just here the road màkes a sudden bend, passes again into light woods, and presently emerges upon a little knoll overlooking the 
upper Franconia meadows. This is the noblest prospect of the afternoon, and late as the hour is growing I must lean against the fence rail - for there is a house at this point also - and gaze upon it. The green meadow is spread at my feet, flaming maple woods range themselves beyond it, and behind them, close at hand, loom the sombre mountains. I had forgotten that this part of the road was so "viewly," to borrow a local word, and am thankful to have reached it at so favorable a moment. Now the shadow of the low hills at my back overspreads the valley, while the upper world beyond is aglow with light and color.

It is five o'clock, and I must be getting homeward. Down at the valley level the evening chill strikes me, after the exceptional warmth of the day, and by the time Tucker Brook is crossed the bare summit of Lafayette is of a deep rosy purple, - the rest of the world sunless. The day is over, and the remaining miles are taken somewhat hurriedly, although I stop below the Profile House farm to look for a fresh bunch of dumb foxglove, - not easy to find in the 
open at this late date, many as the plants are, - and at one or two other places to pluck a tempting maple twig. Sated with the magnificence of autumnal forests, hill after hill splashed with color, the eye loves to withdraw itself now and then to rest upon the perfection of a blossom or a leaf. Wagonloads of tourists come down the Notch road, the usual nightly procession, some silent, some boisterously singing. Among the most distressing of all the noises that human beings make is this vulgar shouting of " sacred music" along the public highway. This time the hymn is Jerusalem the Golden, after the upper notes of which an unhappy female voice is vainly reaching, like a boy who has lost his wind in shinning up a tree, and with his last gasping effort still finds the lowest branch just beyond the clutch of his fingers.

"I know not, oh, I know not,"

I hear her shriek, and then a lucky turn in the road takes her out of hearing, and I listen again to the still small voice of the brook, which, whether it "lknows" or not, has the grace to make no fuss about it. 
Let that one human discord be forgotten. It had been a glorious day; few lovelier were ever made: a day without a cloud (literally), and almost without a breath; a day to walk, and a day to sit still; a long feast of beauty; and withal, it had for me a perfect conclusion, as if Nature herself were setting a benediction upon the hours. As I neared the end of my jaunt, the hotel already in sight, Venus in all her splendor hung low in the west, the full moon was showing its rim above the trees in the east, and at the same moment a vesper sparrow somewhere in the darkening fields broke out with its evening song. Five or six times it sang, and then fell silent. It was enough. The beauty of the day was complete.

The next day, October 1, was no less delightful : mild, still, and cloudless; so that it was pleasant to lounge upon the piazza in the early morning, looking at Lafayette, good business of itself, - and listening to the warble of a bluebird, the soft chips of myrtle warblers, or the distant gobbling of a turkey down at one of the river farms; while now and then a farmer drove past from his 
morning errand at the creamery, with one or two tall milk-cans standing behind him in the open, one-seated carriage. If you see a man on foot as far from the village as this, you may set him down, in ornithological language, as a summer resident or a transient visitor. Franconians, to the manner born, are otherwise minded, and will " hitch up" for a quarter of a mile. As good John Bunyan said, "This is a valley that nobody walks in, but those that love a pilgrim's life."

As I take the Notch road after breakfast the temperature is summer-like, and the foliage, I think, must have reached its brightest. Above the Profile House farm, on the edge of the golf links, where the whole Franconia Valley lies exposed, I seat myself on the wall, inside a natural hedge that borders the highway, to admire the scene: a long verdant meadow, flanked by low hills covered, mile after mile, with vivid reds and yellows; splendor beyond words; a pageant glorious to behold, but happily of brief duration. Human senses would weary of it, though the eye loves color as the palate loves spices and sweets, or, by force of looking at it, would lose all delicacy of perception and taste. 
Even yet the world, viewed in broad spaces, wears a clean, fresh aspect; but near at hand the herbage and shrubbery are all in the sere and yellow leaf. So I am saying to myself when I start at the sound of a Hudsonian chickadee's nasal voice speaking straight into my ear. The saucy chit has dropped into the low poplar sapling over my head, and surprised at what he discovers underneath, lets fall a hasty Sick-a-day-day. His dress, like his voice, compares unfavorably with that of his cousin, our familiar blackcap. In fact, I might say of him, with his dirty brown headdress, what I was thinking of the roadside vegetation: he looks dingy, out of condition, frayed, discolored, belated, frost-bitten. But I am delighted to see him, - for the first time at any such level as this, and thank my stars that I sat down to rest and cool off on this hard but convenient boulder.

A chipmunk thinks I have sat here long enough, and feels no bashfulness about telling me so. Why should he? Frankness is esteemed a point of good manners in all natural society. A man shoots down the hill 
behind me on a bicycle, coasting like the wind, and another, driving up, salutes him by name, and then turns to cry after him in a ringing voice, "How be ye?" The emphatic verb bespeaks a real solicitude on the questioner's part; but he is half a mile too late; he might as well have shouted to the man in the moon. Presently two men in a buggy come up the road, talking in breezy up-country fashion about some one whose name they use freely, - a name well known hereabout, - and with whom they appear to have business relations. "He got up this morning like a —— thousand of brick," one of them says. A disagreeable person to work for, I should suppose. And all the while a child behind the hedge is taking notes. Queer things we could print, if it were allowable to report verbatim.

When this free-spoken pair is far enough in the lead I go back to the road again, traveling slowly and keeping to the shady side, with my coat on my arm. As the climb grows steeper the weather grows more and more like August; and hark! a cicada is shrilling in one of the forest trees, - a long- 
drawn, heat-laden, midsummer cry. I will tell the entomologist about it, I promise myself. The circumstance must be very umusual, and cannot fail to interest her. (But she takes it as a matter of course. It is hard to bring news to a specialist.)

So I go on, up Hardscrabble and Little Hardscrabble, stopping like a short-winded horse at every water-bar, and thankful for every bird-note that calls me to a halt between times. An ornithological preoccupation is a capital resource when the road is getting the better of you. The brook likewise must be minded, and some of the more memorable of the wayside trees. A mountain road has one decided and inalienable advantage, I remark inwardly: the most perversely opinionated highway surveyor in the world cannot straighten it. How fast the leaves are falling, though the air scarcely stirs among them! In some places I walk through a real shower of gold. Theirs is an easy death. And how many times I have been up and down this road! Summer and autumn I have traveled it. And in what pleasant company! Now I am alone; but 
then, the solitude itself is an excellent companionship. We are having a pretty good time of it, I think, - the trees, the brook, the winding road, the yellow birch leaves, and the human pilgrim, who feels himself one with them all. I hope they would not disown a poor relation.

It is ten o'clock. Slowly as I have come, not a wagonload of tourists has caught up with me; and at the Bald Mountain path I leave the highway, having a sudden notion to go to Echo Lake by the way of Artist's Bluff, so called, a rocky cliff that rises abruptly from the lower end of the lake. The trail conducts me through a veritable fernery, one long slope being thickly set with perfectly fresh shield-ferns, - Aspidium spinulosum and perhaps $A$. dilatatum, though I do not concern myself to be sure of it. From the bluff the lake is at my feet, but what mostly fills my eye is the woods on the lower side of Mount Cannon. There is no language to express the kind of pleasure I take in them : so soft, so bright, so various in their hues, - dark green, light green, russet, yellow, red, - all drowned in sun- 
shine, yet veiled perceptibly with haze even at this slight distance. If there is anything in nature more exquisitely, ravishingly beautiful than an old mountainside forest looked at from above, I do not know where to find it.

Down at the lakeside there is beauty of another kind: the level blue water, the clean gray shallows about its margin, the reflections of bright mountains - Eagle Cliff and Mount Cannon - in its face, and soaring into the sky, on either side and in front, the mountains themselves. And how softly the ground is matted under the shrubbery and trees: twin-flower, partridge berry, creeping snowberry, gold-thread, oxalis, dwarf cornel, checkerberry, trailing arbutus! The very names ought to be a means of grace to the pen that writes them.

White-throats and a single winter wren scold at me behind my back as I sit on a spruce $\log$, but for some reason there are few birds here to-day. The fact is exceptional. As a rule, I have found the bushes populous, and once, I remember, not many days later than this, there were fox sparrows with the rest. I am hoping some time to 
find a stray phalarope swimming in the lake. That would be a sight worth seeing. The lake itself is always here, at any rate, especially now that the summer people are gone; and if the wind is right and the sun out, so that a man can sit still with comfort (to-day my coat is superfluous), the absence of other things does not greatly matter.

This clean waterside must have many four-footed visitors, particularly in the twilight and after dark. Deer and bears are common inhabitants of the mountain woods; but for my eyes there is nothing but squirrels, with once in a long while a piece of wilder game. Twice only, in Franconia, have $I$ come within sight of a fox. Once I was alone, in the wood-road to Sinclair's Mills. I rounded a curve, and there the fellow stood in the middle of the way, smelling at something in the rut. After a bit (my glass had covered him instantly) he raised his head and looked down the road in a direction opposite to mine. Then he turned, saw me, started slightly, stood quite still for a fraction of a minute ( $I$ wondered why), and vanished in the woods, his white 
brush waving me farewell. He was gone so instantaneously that it was hard to believe he had really been there.

That was a pretty good look (at a fox), but far less satisfying than the other of my Franconia experiences. With two friends I had come down through the forest from the Notch railroad by a rather blind loggers' trail, heading for a pair of abandoned farms, grassy fields in which it is needful to give heed to one's steps for fear of bear-traps. As we emerged into the first clearing a fox was not more than five or six rods before us, feeding in the grass. Her eyes were on her work, the wind was in our favor, and notwithstanding two of us were almost wholly exposed, we stood there on the edge of the forest for the better part of half an hour, glasses up, passing comments upon her behavior. Evidently she was lunching upon insects, - grasshoppers or crickets, I suppose, - and so taken up was she with this agreeable employment that she walked directly toward us and passed within ten yards of our position, stopping every few steps for a fresh capture. The sunlight, which shone 
squarely in her face, seemed to affect her unpleasantly; at all events she blinked a good deal. Her manner of stepping about, her motions in catching her prey, - driving her nose deep into the grass and pushing it home, - and in short her whole behavior, were more catlike than doglike, or so we all thought. Plainly she had no idea of abbreviating her repast, nor did she betray the slightest grain of suspiciousness or wariness, never once casting an eye about in search of possible enemies. A dog in his own dooryard could not have seemed less apprehensive of danger. As often as she approached the surrounding wood she turned and hunted back across the field. We might have played the spy upon her indefinitely; but it was always the same thing over again, and by and by, when she passed for a little out of sight behind a tuft of bushes, we followed, careless of the result, and, as it seemed, got into her wind. She started on the instant, ran gracefully up a little incline, still in the grass land, turned for the first time to look at us, and disappeared in the forest. A pretty creature she 
surely was, and from all we saw of her she might have been accounted a very useful farm-hand; but perhaps, as farmers sometimes say of unprofitable cattle, she would soon have "eaten her head off" in the poultry yard. She was not fearless, - like a woodchuck that once walked up to me and smelled of my boot, as I stood still in the road near the Crawford House, _ but simply off her guard; and our finding her in such a mood was simply a bit of good luck. Some day, possibly, we shall catch a weasel asleep.

In a vacation season, like our annual fortnight in New Hampshire, there is no predicting which jaunt, if any, will turn out superior to all the rest. It may be a longer and comparatively newer one (although in Franconia we find few new ones now, partly because we no longer seek them - the old is better, we are apt to say when any innovation is suggested); or, thanks to something in the day or something in the mood, it may be one of the shortest and most familiar. And when it is over, there may be a sweetness in the memory, but little to talk about; 
little "incident," as editors say, little that goes naturally into a notebook. In other words, the best walk, for us, is the one in which we are happiest, the one in which we feel the most, not of necessity the one in which we see the most; or, to put it differently still, the one in which we do see the most, but with

\section{" that inward eye}

Which is the bliss of solitude."

Whatever we may call ourselves at home, among the mountains we are lovers of pleasure. Our day's work is to be happy. We take our text from the good Longfellow as theologians take theirs from Scripture:-

"Enjoyment, and not sorrow, is our destined end."

We are not anxious to learn anything; our thoughts run not upon wisdom; if we take note of a plant or a bird, it is rather for the fun of it than for any scholarly purpose. We are boys out of school. I speak of myself and of the man I have called my walking mate. The two collectors of insects, of course, are more serious-minded. "No day without a beetle," is their motto, and their absorption, even in Franconia, is in adding 
to the world's stock of knowledge. Let them be respected accordingly. Our creed is more frankly hedonistic; and their virtue - I am free to confess it - shines the brighter for the contrast.

This year, nevertheless, old Franconia had for us, also, one most welcome novelty, the story of which I have kept, like the good wine, - a pretty small glassful, I am aware, - for the end of the feast. I had never enjoyed the old things better. Eight or nine years ago, writing - in this magazine 1 - of June in Franconia, I expressed a fear that our delight in the beauty of nature might grow to be less keenly felt with advancing age; that we might ultimately be driven to a more scientific use of the outward world, putting the exercise of curiosity, what we call somewhat loftily the acquisition of knowledge, in the place of rapturous contemplation. So it may yet fall out, to be sure, since age is still advancing, but as far as present indications go, nothing of the sort seems at all imminent. I begin to believe, in fact, that things will turn the other way;

1 The Atlantic Monthly. 
that curiosity will rather lose its edge, and the power of beauty strike deeper and deeper home. So may it be! Then we shall not be dead while we live. Sure I am that the glory of mountains, the splendor of autumnal forests, the sweetness of valley prospects, were never more rapturously felt by me than cluring the season just ended. And still, as I started just now to say, I had special joy this year in a new specimen, an additional bird for my memory and notebook.

The forenoon of September 26, my fourth day, I spent on Garnet Hill. The grand circuit of that hill is one of the best esteemed of our longer expeditions. Formerly we did it always between breakfast and dinner, having to speed the pace a little uncomfortably for the last four or five miles; but times have begun to alter with us, or perhaps we have profited by experience ; for the last few years, at any rate, we have made the trip an all-day affair, dining on Sunset Hill, and loitering down through the Landaff Valley with a side excursion, it may be, to fill up the hours - in the afternoon. This trip, being, as I say, one of those we most set by, 
I was determined to hold in reserve against the arrival of my fellow foot-traveler; but there is also a pleasant shorter course, not round the hill, but, so to speak, over one side of it: out by the way of what I call High Bridge Road (never having heard any name for it), and back by the road - hardly more than a lane for much of its length which traverses the hill diagonally on its northeastern slope, and joins the regular $\mathrm{Su}$ gar Hill highway a little below the Franconia Inn.

I left the Littleton road for the road to the Streeter neighborhood, crossed Gale River by a bridge pitched with much labor at a great height above it (a good indication of the swelling to which mountain streams are subject), passed two or three retired valley farms (where were eight or ten sleek young calves, one of which, rather to my surprise, ate from my hand a sprig of mint as if she liked the savor of it), and then began a long, steep climb. For much of the distance the road - narrow and very little traveled - is lined with dense alder and willow thickets, excellent cover for birds. It was 
partly with this place in my eye that I had chosen my route, remembering an hour of much interest here some years ago with a large flock of migrants. To-day, as it happened, the bushes were comparatively birdless. White-throats and snowbirds were present, of course, and ruby-crowned kinglets, with a solitary vireo or two, but nothing out of the ordinary. The prospect, however, without being magnificent or - for Franconia - extensive, was full of attractiveness. Gale River hastening through a gorge overhung with forest, directly on my right, Streeter Pond farther away (two deer had been shot beside it that morning, as I learned before night, - news of that degree of importance travels fast), and the gay-colored hills toward Littleton and Bethlehem, maple grove on maple grove, with all their banners flying, - these made a delightsome panorama, shifting with every twist in the road and with every rod of the ascent; so that I had excuse more than sufficient for continually stopping to breathe and face about. In one place I remarked a goodly bed of coltsfoot leaves, noticeable for their 
angular shape as well as for their peculiar shade of green. I wished for a blossom. If the dandelion sometimes anticipates the season, why not the coltsfoot? But I found no sign of flower or bud. Probably the plant is of a less impatient habit; but I have seen it so seldom that all my ideas about it are no better than guesswork. Along the wayside was maiden-hair fern, also, which I do not come upon any too often in this mountain country.

Midway of the hill stands a solitary house, where I found my approach spied upon through a crack between the curtain and the sash of what seemed to be a parlor window; a flattering attention which, after the manner of high public functionaries, I took as a tribute not to myself, but to the rôle I was playing. No doubt travelers on foot are rare on that difficult, out-of-the-way road, and the walker rather than the man was what filled my lady's eye; unless, as may easily have been true, she was expecting to see a peddler's pack. At this point the road crooks a sharp elbow, and henceforth passes through cultivated country, - or- 
chards and ploughed land, grass fields and pasturage; still without houses, however, and having a pleasant natural hedgerow of trees and shrubbery. In one of the orchards was a great congregation of sparrows and myrtle warblers, with sapsuckers, flickers, downy woodpeckers, solitary vireos, and I forget what else, though I sat on the wall for some time refreshing myself with their cheerful society. I agreed with them that life was still a good thing.

Then came my novelty. I was but a little way past this aviary of an apple orchard when I approached a pile of brush, _ dry branches which had been heaped against the roadside bank some years ago, and up through which bushes and weeds were growing. My eyes sought it instinctively, and at the same moment a bird moved inside. A sparrow, alone; a sparrow, and a new one! "A Lincoln finch!" I thought; and just then the creature turned, and I saw his forward parts: a streaked breast with a bright, well-defined buff band across it, as if the streaks had been marked in first and then a wash of yellowish had been laid on 
over them. Yes, a Lincoln finch! He was out of sight almost before I saw him, however, and after a bit of feverish waiting I squeaked. He did not come up to look at me, as I hoped he would do, but the sudden noise startled him, and he moved slightly, enough so that my eye again found him. This time, also, I saw his head and his breast, and then he was lost again. Again I waited. Then I squeaked, waited, and squeaked again, louder and longer than before. No answer, and no sign of movement. You might have sworn there was no bird there; and perhaps you would not have perjured yourself; for presently I stepped up to the brush-heap and trampled it over, and still there was no sign of life. Above the brush was a low stone wall, and beyond that a bare ploughed field. How the fellow had slipped away there was no telling. And that was the end of the story. But I had seen him, and he was a Lincoln finch. It was a shabby interview he had granted me, after keeping me waiting for almost twenty years; but then, I repeated for my comfort, I had seen him. 
He was less confusingly like a song sparrow than I had been prepared to find him. His general color (one of a bird's best marks in life, hard as it may be to derive an exact idea of it from printed descriptions), gray with a greenish tinge, - a little suggestive of Henslow's bunting, as it struck me, this, I thought, supposing it to be constant, ought to catch the eye at a glance. Henceforth I should know what to look for, and might expect better luck; although, if this particular bird's behavior was to be taken as a criterion, the books had been quite within the mark in emphasizing the sly and elusive habit of the species, and the consequent difficulty of prolonged and satisfactory observation of it.

The Lincoln finch, or Lincoln sparrow, the reader should know, is a congener of the song sparrow and the swamp sparrow, a native mostly of the far north, and while common enough as a migrant in many parts of the United States, is, or is generally supposed to be, something of a rarity in the Eastern States.

Meanwhile, having beaten the brush over, 
and looked up the roadside and down the roadside and over the wall, I went on my way, stopping once for a feast of blackberries, - as many and as good as a man could ask for, long, slender, sweet, and dead ripe ; and at the top of the road I cut across a hayfield to the lane before mentioned, that should take me back to the Sugar Hill highway. Now the prospects were in front of me, there was no more steepness of grade, I had seen Tom Lincoln's finch, ${ }^{1}$ and the day was brighter than ever. Every sparrow that stirred I must put my glass on; but not one was of the right complexion.

Then, in a sugar grove not far from the Franconia Inn, I found myself all at once in the midst of one of those traveling flocks that make so delightful a break in a birdlover's day. I was in the midst of it, I say; but the real fact was that the birds were passing through the grove between me and the sky. For the time being the branches were astir with wings. Such minutes are exciting. "Now or never," a man says to

1 "I named it Tom's Finch," says Audubon, "in honor of our friend Lincoln, who was a great favorite among us." 
himself. Every second is precious. At this precise moment a warbler is above your head, far up in the topmost bough perhaps, half hidden by a leaf. If you miss him, he is gone forever. If you make him out, well and good; he may be a rarity, a prize long waited for; or, quite as likely, while busy with him you may let a ten times rarer one pass unnoticed. In this game, as in any other, a man must run his chances; though there is skill as well as luck in it, without doubt, and one player will take a trick or two more than another, with the same hand.

In the present instance, so far as my canvass showed, the "wave" was made up of myrtle warblers, blackpolls, baybreasts, black-throated greens, a chestnut-side, a Maryland yellow-throat, red-eyed vireos, solitary vireos, one or more scarlet tanagers (in undress, of course, and pretty late by my reckoning), ruby-crowned kinglets, chickadees, winter wrens, goldfinches, song sparrows, and flickers. The last three or four species, it is probable enough, were in the grove only by accident, and are hardly to be counted as part of the south-bound 
caravan. Several of the species were in good force, and doubtless some species eluded me altogether. No man can look all ways at once; and in autumn the eyes must do not only their own work, but that of the ears as well.

All the while the birds hastened on, flitting from tree to tree, feeding a minute and then away, following the stream. I was especially glad of the baybreasts, of which there were two at least, both very distinctly marked, though in nothing like their spring plumage. I saw only one other specimen this fall, but the name is usually in my autumnal Franconia list. The chestnut-side, on the other hand, was the first one I had ever found here at this season, and was correspondingly welcome.

After all, a catalogue of names gives but a meagre idea of such a flock, except to those who have seen similar ones, and amused themselves with them in a similar manner. But I had had the fun, whether I can make any one else appreciate it or not, and between it and my joy over the Lincoln finch I went home in high feather. 
Five days longer I followed the road alone. Every time a sparrow darted into the bushes too quickly for me to name him, I thought of Melospiza lincolni. Once, indeed, on the Bethlehem road, I believed that I really saw a bird of that species; but it was in the act of disappearing, and no amount of pains or patience - or no amount that I had to spare - could procure me a second glimpse.

On the sixth day came my friend, the second foot-passenger, and was told of my good fortune; and together we began forthwith to walk - and look at sparrows. This, also, was vain, until the morning of October 4. I was out first. A robin was cackling from a tall treetop, as I stepped upon the piazza, and a song sparrow sang from a cluster of bushes across the way. Other birds were there, and I went over to have a look at them: two or three white-throats, as many song sparrows, and a white-crown. Then by squeaking I called into sight two swamp sparrows (migrants newly come, they must be, to be found in such a place), and directly afterward up hopped a small gray- 
ish sparrow, seen at a glance to be like my bird of nine days before, - like him in looks, but not in behavior. He conducted himself in the most accommodating manner, was full of curiosity, not in the least shy, and afforded me every opportunity to look him over to my heart's content.

In the midst of it all I heard my comrade's footfall on the piazza, and gave him a whistle. He came at once, wading through the wet grass in his slippers. He knew from my attitude - so he firmly declared afterward - that it was a Lincoln finch I was gazing at! And just as he drew near, the sparrow, sitting in full view and facing us, in a way to show off his peculiar marks to the best advantage, uttered a single cheep, thoroughly distinctive, or at least quite unlike any sparrow's note with which I am familiar; as characteristic, I should say, as the song sparrow's tut. Then he dropped to the ground. "Yes, I saw him, and heard the note," my companion said; and he hastened into the house for his boots and his opera-glass. In a few minutes he was back again, fully equipped, and we set 
ourselves to coax the fellow into making another display of himself. Sure enough, he responded almost immediately, and we had another satisfying observation of him, though this time he kept silence. I was especially interested to find, what I had on general considerations suspected, that Lincoln finches were like other members of their family. Take them right (by themselves, and without startling them to begin with), and they could be as complaisant as one could desire, no matter how timid and elusive they might be under different conditions. Our bird was certainly a jewel. For a while he pleased us by perching side by side with a song sparrow. "You see how much smaller I am," he might have been saying ; "you may know me partly by that."

And we fancied we should know him thereafter; but a novice's knowledge is only a novice's, as we were to be freshly reminded that very day. Our jaunt was round Garnet Hill, the all-day expedition before referred to. I will not rehearse the story of it; but while we were on the farther side of the hill, somewhere in Lisbon, we 
found the roadsides swarming with sparrows, - a mixed flock, song sparrows, field sparrows, chippers, and white-crowns. Among them one of us by and by detected a grayish, smallish bird, and we began hunting him, from bush to bush and from one side of the road to the other, carrying on all the while an eager debate as to his identity. Now we were sure of him, and now everything was unsettled. His breast was streaked and had a yellow band across it. His color and size were right, as well as we could say, - so decidedly so that there was no difficulty whatever in picking him out at a glance after losing him in a flying bunch; but some of his motions were pretty songsparrow-like, and what my fellow observer was most staggered by, he showed a blotch, a running together of the dark streaks, in the middle of the breast, - a point very characteristic of the song sparrow, but not mentioned in book descriptions of Melospiza lincolni. So we chased him and discussed him (that was the time for a gun, the professional will say), till he got away from us for good. 
Was he a Lincoln finch? Who knows? We left the question open. But I believe he was. The main reason, not to say the only one, for our uncertainty was the pectoral blotch; and that, I have since learned, is often seen in specimens of Melospiza lincolni. Why the manuals make no reference to it I cannot tell; as I cannot tell why they omit the same point in describing the savanna sparrow. In scientific books, as in "popular" magazine articles, many things must no doubt be passed over for lack of room. In any case, it is not the worst misfortune that could befall us to have some things left for our own finding out.

And after all, the question was not of supreme importance. Though I was delighted to have seen a new bird, and doubly delighted to have seen it in Franconia, the great joy of my visit was not in any such fragment of knowledge, but in that bright and glorious world; mountains and valleys beautiful in themselves, and endeared by the memory of happy days among them. Sometimes I wonder whether the pleasures of memory may not be worth the price of growing old. 


\section{SPRING}

"He would now be up every morning by break of day, walking to and fro in the valley." - BUNYAN.

Ir was a white day, the day of the red cherry, - by the almanac the 20th of May. Once in the hill country, the train ran hour after hour through a world of shrubs and small trees, loaded every one with blossoms. Their number was amazing. I should not have believed there were so many in all New Hampshire. The snowy branches fairly whitened the woods; as if all the red-cherry trees of the country round about were assembled along the track to celebrate a festival. The spectacle - for it was nothing less - made me think of the annual dogwood display as I had witnessed it in the Alleghanies and further south. I remembered, too, a similar New England pageant of some years ago; a thing of annual occurrence, of course, but never seen by me before or 
since. Then it happened that I came down from Vermont (this also was in May) just at the time when the shadbushes were in their glory. Like the wild red-cherry trees, as I saw them now, they seemed to fill the world. Such miles on miles of a floral panorama are among the memorable delights of spring travel.

For the cherry's sake I was glad that my leaving home had been delayed a week or two beyond my first intention; though I thought then, as I do still, that an earlier start would have shown me something more of real spring among the mountains, which, after all, was what I had come out to see.

The light showers through which I drove over the hills from Littleton were gone before sunset, and as the twilight deepened I strolled up the Butter Hill road as far as the grove of red pines, just to feel the ground under my feet and to hear the hermit thrushes. How divinely they sang, one on either side of the way, voice answering to voice, the very soul of music, out of the darkening woods! I agree with a friendly correspondent who wrote me, the other day, 
fresh from a summer in France, that the nightingale is no such singer. I have never heard the nightingale, but that does not alter my opinion. Formerly I wished that the hermit, and all the rest of our woodland thrushes, would practice a longer and more continuous strain. Now I think differently; for I see now that what I looked upon as a blemish is really the perfection of art. Those brief, deliberate phrases, breaking one by one out of the silence, lift the soul higher than any smooth-flowing warble could possibly do. Worship has no gift of long-breathed fluency. If she speaks at all, it is in the way of ejaculation: "Therefore let thy words be few," said the Preacher, - a text which is only a modern Hebrew version of what the hermit thrush has been saying here in the White Mountains for ten thousand years.

One of the principal glories of Franconia is the same in spring as in autumn, - the colors of the forest. There is no describing them: greens and reds of all tender and lovely shades; not to speak of the exquisite haze-blue, or blue-purple, which mantles the still budded woods on the higher slopes. For 
the reds I was quite unprepared. They have never been written about, so far as I know, doubtless because they have never been seen. The scribbling tourist is never here till long after they are gone. In fact, I stayed late enough, on my present visit, to see the end of them. I knew, of course, that young maple leaves, like old ones, are of a ruddy complexion; ${ }^{1}$ but somehow I had never considered that the massing of the trees on hillsides would work the same gorgeous, spectacular effect in spring as in autumn, - broad patches of splendor hung aloft, a natural tapestry, for the eye to feast upon. Not that May is as gaudy as September. There are no brilliant yellows, and the reds are many shades less fiery than autumn furnishes; but what is lacking in intensity is more than made up in delicacy, as the bloom of youth is fairer than any hectic flush. The glory passed, as I have said. Before the 1st of June it had deepened, and then disappeared; but the sight of it was of itself enough to reward my journey.

1 But the brightness of red-maple groves at this season is mostly not in the leaves, but in the fruit. 
The clouds returned after the rain, and my first forenoon was spent under an umbrella on the Bethlehem plateau, not so much walking as standing about; now in the woods, now in the sandy road, now in the dooryard of an empty house. It was Sunday; the rain, quiet and intermittent, rather favored music; and all in all, things were pretty much to my mind, - plenty to see and hear, yet all of a sweetly familiar sort, such as one hardly thinks of putting into a notebook. Why record, as if it could be forgotten or needed to be remembered, the lisping of happy chickadees or the whistle of whitethroated sparrows? Or why speak of shadblow and goldthread, or even of the lovely painted trilliums, with their three daintily crinkled petals, streaked with rose-purple? The trilliums, indeed, well deserved to be spoken of : so bright and bold they were; every blossom looking the sun squarely in the face, - in great contrast with the pale and bashful wake-robin, which I find (by searching for it) in my own woods. One after another I gathered them (pulled them, to speak with poetic literalness), each fresher 
and handsomer than the one before it, till the white stems made a handful.

"Oh," said a man on the piazza, as I returned to the hotel, "I see you have nosebleed." I was putting my hand to my pocket, wondering why I should have been taken so childishly, when it came over me what he meant. He was looking at the trilliums, and explained, in answer to a question, that he had always heard them called " nosebleed." Somewhere, then, - I omitted to inquire where, — this is their "vulgar" name. In Franconia the people call them "Benjamins," which has a pleasant Biblical sound, - better than " nosebleed," at all events, - though to my thinking " trillium " is preferable to either of them, both for sound and for sense. People cry out against "Latin names." But why is Latin worse than Hebrew? And who could ask anything prettier or easier than trillium, geranium, anemone, and hepatica?

The next morning I set out for Echo Lake. At that height, in that hollow among the mountains, the season must still be young. There, if anywhere, I should find the early 
violet and the trailing mayflower. And whatever I found, or did not find, at the end of the way, I should have made another ascent of the dear old Notch road, every rod of it the pleasanter for happy memories. I had never traveled it in May, with the glossy-leaved clintonia yet in the bud, and the broad, grassy golf links above the Profile House farm all frosty with houstonia bloom. And many times as I had been over it, I had never known till now that rhodora stood along its very edge. To-day, with the pink blossoms brightening the crooked, leafless, knee-high stems, not even my eyes could miss it. Our one small pearleaved willow, near the foot of Hardscrabble, was in flower, its maroon leaves partly grown. Well I remembered the June morning when I lighted upon it, and the interest shown by the senior botanist of our little company when I reported the discovery, at the dinner table. He went up that very afternoon to see it for himself; and year after year, while he lived, he watched over it, more than once cautioning the road-menders against its destruction. How many times he and I have stopped be- 
side it, on our way up and down! The "Torrey willow" he always called it, stroking my vanity; and I liked the word.

Now a chipmunk speaks to me, as I pass; it is not his fault, nor mine either, perhaps, that I do not understand him; and now, hearing a twig snap, I glance up in time to see a woodchuck scuttling out of sight under the high, overhanging bank. So he is a dweller in these upper mountain woods! 1 I should have thought him too nice an epicure to feel himself at home in such diggings. But who knows? Perhaps he finds something hereabout - wood-sorrel or what not - that is more savory even than young clover leaves and early garden sauce. From somewhere on my right comes the sweet honey-sweet — warble of a rose-breasted grosbeak; and almost over my head, at the topmost point of a tall spruce, sits a Blackburnian warbler, doing his little utmost to express himself. His pitch is as high as his perch, and his tone, pure $z$, is like the finest of wire. Another water bar surmounted, and

1 Yes, he has even been seen (and "taken"), so I am told, at the summit of Mount Washington. 
a baybreast sings, and lets me see him, - a bird I always love to look at, and a song that I always have to learn anew, partly because I hear it so seldom, partly because of its want of individuality: a single hurried phrase, pure $\approx$ like the Blackburnian's, and of the same wire-drawn tenuity. These warblers are poor hands at warbling, but they are musical to the eye. By this rule, - if throats were made to be looked at, and judged by the feathers on them, — the Blackburnian might challenge comparison with any singer under the sun.

As the road ascends, the aspect of things grows more and more springlike, - or less and less summerlike. Black-birch catkins are just beginning to fall, and a little higher, not far from the Bald Mountain path, I notice a sugar maple still hanging full of pale straw-colored tassels, - encouraging signs to a man who was becoming apprehensive lest he had arrived too late.

Then, as I pass the height of land and begin the gentle descent into the Notch, fronting the white peak of Lafayette and the black face of Eagle Cliff, I am aware of a 
strange sensation, as if I had stepped into another world : bare, leafless woods and sudden blank silence. All the way hitherto birds have been singing on either hand, my ear picking out the voices one by one, while flies and mosquitoes have buzzed continually about my head; here, all in a moment, not a bird, not an insect, - a stillness like that of winter. Minute after minute, rod after rod, and not a breath of sound, - not so much as the stirring of a leaf. I could not have believed such a transformation possible. It is uncanny. I walk as in a dream. The silence lasts for at least a quarter of a mile. Then a warbler breaks it for an instant, and leaves it, if possible, more absolute than before. I am going southward, and downhill; but I am going into the Noteh, into the very shadow of the mountains, where Winter makes his last rally against the inevitable.

And yes, here are some of the early flowers I have come in search of: the dear little yellow violets, whose glossy, round leaves, no more than half-grown as yet, seem to love the very border of a snowbank. Here, too, is a most flourishing patch of spring-beauties, 
and another of adder's-tongue, - dog-tooth violet, so called. Of the latter there must be hundreds of acres in Franconia. I have seen the freckled leaves everywhere, and now and then a few belated blossoms. Here I have it at its best, the whole bed thick with buds and freshly blown flowers. But the round-leaved violet is what I am chiefly taken with. The very type and pattern of modesty, I am ready to say. The springbeauty masses itself ; and though every blossom, if you look at it, is a miracle of delicacy, - lustrous pink satin, with veinings of a deeper shade, - it may fairly be said to make a show. But the violets, scattered, and barely out of the ground, must be sought after one by one. So meek, and yet so bold! - part of the beautiful vernal paradox, that the lowly and the frail are the first to venture.

As I come down to the lakeside, - making toward the lower end, whither I always go, because there the railroad is least obtrusively in sight and the mountains are faced to the best advantage, - two or three solitary sandpipers flit before me, tweeting and 
bobbing, and a winter wren (invisible, of course) sings from a thicket at my elbow. A jolly songster he is, with the clearest and finest of tones - a true fife - and an irresistible accent and rhythm. A bird by himself. This fellow hurries and hurries (am I wrong in half remembering a line by some poet about a bird that " hurries and precipitates"?), 1 till the tempo becomes too much for him; the notes can no longer be taken, and, like a boy running down too steep a hill, he finishes with a slide. I think of those pianoforte passages which the most lightninglike of performers - Paderewski himself - are reduced to playing ignominiously with the back of one finger. I know not their technical name, if they have one, finger-nail runs, perhaps. I remember, also, Thoreau's description of a song heard in Tuckerman's Ravine and here in the Franconia Notch. He could never discover the author of it, but pretty certainly it was the winter wren. "Most peculiar and memo-

1 No, the line is Coleridge's : " the merry nightingale

That crowds, and hurries, and precipitates With fast thick warble his delicious notes." 
rable," he pronounces it, like a "fine corkscrew stream issuing with incessant tinkle from a cork." "Tinkle" is exactly the word. Trust Thorean to find that, though he could not find the singer. If the thrushes are left out of the account, there is no voice in the mountains that I am gladder to hear.

Near the outlet of the lake, in a shaded hollow, lies a deep snowbank, and not far away the ground is matted with trailing arbutus, still in plentiful bloom. One of the most attractive things here is the few-flowered shadbush (Amelanchier oligocarpa). The common $A$. Canadensis grows near by ; and it is astonishing how unlike the two species look, although the difference (the visible difference, I mean) is mostly in the arrangement of the flowers, - clustered in one case, separately disposed in the other. Today the "average observer" would look twice before suspecting any close relationship between them; a week or two hence he would look a dozen times before remarking any distinction. With them, as with the red cherry, it is the blossom that makes the bush. 
So much for my first May morning on the Notch road and by the lake: a few particulars caught in passing, to be taken for what they are, -

"Samples and sorts, not for themselves alone, but for their atmosphere."

In the afternoon I went over into the Landaff Valley, having in mind a restful, level-country stroll, with a view especially to the probable presence of Tennessee warblers in that quarter. One or two had been singing constantly near the hotel for two days (ever since my arrival, that is), and Sunday I had heard another beside the Bethlehem road. Whether they were migrants only, or had settled in Franconia for the season, they ought, it seemed to me, to be found also in the big Landaff larch swamp, where we had seen them so often in June, ten or twelve years ago. As I had heard the song but once since that time, I was naturally disposed to make the most of the present opportunity.

I turned in at the old hay barn, - one of my favorite resorts, where I have seen many a pretty bunch of autumnal transients, - 
and sure enough, a Tennessee's voice was one of the first to greet me. This fellow sang as a Tennessee ought to sing, I said to myself. By which I meant that his song was clearly made up of three parts, just as I had kept it in memory; whereas the birds near the hotel, as well as the one on the Bethlehem road, divided theirs but once. No great matter, somebody will say; but a self-respecting man likes to have his recollections justified, even about trifles, particularly when he has confided them to print. ${ }^{1}$

The swamp had begun well with its old eulogist; but better things were in store. I passed an hour or more in the woods, for the

1 So I was relieved to find all the Franconia whitethroated sparrows introducing their sets of triplets with two - not three - longer single notes. That was how I had always whistled the tune ; and I had been astonished and grieved to see it printed in musical notation by Mr. Cheney, and again by Mr. Chapman, with an introductory measure of three notes: as if it were to go, "Old Sam, Sam Peabody, Peabody, Peabody," instead of, as I remembered it, and as reason dictated, "Old Sam Peabody, Peabody, Peabody." I am not intimating that Mr. Cheney and Mr. Chapman are wrong, but that my own recollection was right, - a very different matter, as my present experience with Tennessee warblers was sufficient to show. 
most part sitting still (which is pretty good after-dinner ornithology), and had just taken the road again when a bevy of talkative chickadees came straggling down the rim of the swamp, flitting from one tree to another, - a morsel here and a morsel there, — after their usual manner while on the march. Now, then, for a few migratory warblers, which always may be looked for in such company.

True to the word, my glass was hardly in play before a bay-breast showed himself, in magnificent plumage; then came a Blackburnian, also in high feather, handsomer even than the bay-breast, but less of a rarity; and then, all in a flash, I caught a glimpse of some bright-colored, black-andyellow bird that, almost certainly, from an indefinable something half seen about the head, could not be a magnolia. "That should be a Cape May!" I said aloud to myself. Even as I spoke, however, he was out of sight. Down the road I went, trying to keep abreast of the flock, which moved much too rapidly for my comfort. Again I saw what might have been the Cape May, but 
again there was nothing like certainty. And again I lost him. With the trees so thick, and the birds so small and so active, it was impossible to do better. I had missed my chance, I thought; but just then something stirred among the leaves of a fir tree close by me, on the very edge of the swamp, and the next moment a bird stepped upon the outermost twig, as near me as he could get, and stood there fully displayed: a splendid Cape May, in superb color, my first New England specimen. "Look at me," he said ; "this is for your benefit." And I looked with both eyes. Who would not be an ornithologist, with sights like this to reward him?

The procession moved on, by the air line, impossible for me to follow. The Cape May, of course, had departed with the rest. So I assumed, - without warrant, as will presently appear. But I had no quarrel with Fate. For a plodding, wingless creature, long accustomed to his disabilities, I was being handsomely used. The soul is always seeking new things, says a celebrated French philosopher, and is always pleased 
when it is shown more than it had hoped for. This is preëminently true of rare warblers. Now I would cross the bridge, walk once more under the arch of willows, happy that I could walk, being a man only, - and back to the village again by the upper road. For a half mile on that road the prospect is such that no mortal need desire a better one.

First, however, I must train my glass upon a certain dark object out in the meadow, to see whether it was a stump (it was motionless enough for one, but I did n't remember it there) or a woodchuck. It turned out to be a woodchuck, erect upon his haunches, his fore paws lifted in an attitude of devotion. The sight was common just now in all Franconia grassland, no matter in what direction my jaunts took me. And always the attitude was the same, as if now were the ground-hog's Lent. "Watch and pray" is his motto; and he thrives upon it like a monk. Though the legislature sets a price on his head, he keeps in better flesh than the average legislator. Well done, say I. May his shadow never grow less! I like 
him, as I like the crow. Health and long life to both of them, — wildings that will not be put down nor driven into the outer wilderness, be the hand of civilization never so hostile. They were here before man came, and will be here, it is most likely, after he is gone; unless, as the old planet's fires go out, man himself becomes a hibernator. I have heard a hunted woodchuck, at bay in a stone wall, gnashing his teeth against a dog; and I have seen a mother woodchuck with a litter of young ones playing about her as she lay at full length sunning herself, the very picture of maternal satisfaction: and my belief is that woodchucks have as honest a right as most of us to life, liberty, and the pursuit of happiness.

As I walked under the willows, - empty to-day, though I remembered more than one happy occasion when, in better company, I had found them alive with wings, - I paused to look through the branches at a large hawk and a few glossy-backed barn swallows quartering over the meadow. Then, all at once, there fell on my ears a shower of bobolink notes, and the birds, 
twenty or more together, dropped into the short grass before me. Every one of them was a male.

A strange custom it is, this Quakerish separation of the sexes. It must be the females' work, I imagine. Modesty and bashfulness are feminine traits, - modesty, bashfulness, and maidenly discretion. The wise virgin shunneth even the appearance of evil. Let the males flock by themselves, and travel in advance. And the males practice obedience, not for virtue's sake, I guess, but of necessity; encouraged, no doubt, by an unquestioning belief that the wise virgins will come trooping after, and be found scattered conveniently over the meadows, each by herself, when the marriage bell strikes. That blissful hour was now close at hand, and my twenty gay bachelors knew it. Every bird of them had on his wedding garment. No wonder they sang.

It took me a long time to make that half mile on the upper road, with the narrow, freshly green valley outspread just below, the river running through it, and beyond 
a royal horizonful of mountains; some near and green, some farther away and blue, and some - the highest — still with the snow on them: Moosilauke, Kinsman, Cannon, Lafayette, Garfield, the Twins, Washington, Clay, Jefferson, and Adams; all perfectly clear, the sky covered with high clouds. A sober day it was, sober and still, though the bobolinks seemed not so to regard it. While I looked at the landscape, seating myself now and then to enjoy it quietly, I kept an ear open for the shout of a pileated woodpecker, a wildly musical sound often to be heard on this hillside; but to-day there was nothing nearer to it than a crested flycatcher's scream, out of the big sugar orchard.

On my way down the hill toward the red bridge, I met a man riding in some kind of rude contrivance, not to be called a wagon or a cart, between two pairs of wheels. He lay flat on his back, as in a hammock, and, to judge by his tools and the mortar on his clothing, must have been a mason returning from his work. He was "taking it easy," at all events. We saluted each other, and 
he stopped his horse and sat up. "You used to be round here, did n't you?" he asked. Yes, I said, I had been here a good deal, off and on. He thought he remembered me. He had noticed me getting out of Mr. Prime's carriage at the corner. "Let's see," he said: "you used to be looking after the birds a good deal, did n't you?" I pleaded guilty, and he seemed glad. "You are well ?" he added, and drove on. Neither of us had said anything in particular, but there are few events of the road more to my taste than such chance bits of neighborly intercourse. The man's tone and manner gave me the feeling of real friendliness. If I had fallen among thieves, I confide that he would have been neither a priest nor a Levite. May his trowel find plenty of work and fair wages.

This was on May 22. The next three days were occupied with all-day excursions to Mount Agassiz, to Streeter Pond, and to Lonesome Lake path. With so many hands beckoning to me, the Cape May warbler was well-nigh forgotten. On the morning of the 26th, however, the weather being du- 
bious, I betook myself again to the Landaff swamp, entering it, as usual, by the wood road at the barn. Many birds were there: a tanager (uncommon hereabout), olivesided flycatchers, alder flycatchers (first seen on the 23d, and already abundant), a yellow-bellied flycatcher (the recluse of the family), magnolia warblers, Canada warblers, parula warblers (three beautiful species), a Tennessee warbler, a Swainson thrush (whistling), a veery (snarling), and many more. The Swainson thrush, by the way, although present, in small numbers apparently, from May 22, was not heard to sing a note until June 1 , - ten days of silence! Yet it sings freely on its migration, even as far south as Georgia. Close at hand was a grouse, who performed again and again in what seemed to me a highly original manner. First he delivered three or four quick beats. Then he rested for a second or two, after which he proceeded to drum in the ordinary way, beginning with deliberation, and gradually accelerating the beats, till the ear could no longer follow them, and they became a whir. That pre- 
lude of four quick, decisive strokes was a novelty to my ears, so far as I could remember.

I had taken my fill of this pleasant chorus, and was on my way back to the road, when suddenly I heard something that was better than "pleasant," - a peculiarly faint and listless four-syllabled warbler song, which might be described as a monotonous zee-zeezee-zee. The singer was not a blackpoll : of that I felt certain on the instant. What could it be, then, but a Cape May? That was a shrewd guess (I had heard the Cape May once, in Virginia, some years before); for presently the fellow moved into sight, and $I$ had a feast of admiring him, as he flitted about among the fir trees, feeding and singing. If he was the one I had seen in the same wood on the $22 \mathrm{~d}$, he was making a long stay. Still I did not venture to think of him as anything but a migrant. The Tennessee had sung incessantly for five days in the Gale River larches near the hotel, as already mentioned, and then had taken flight.

The next morning, nevertheless, there was 
nothing for it - few as my days were growing - but I must visit the place again, on the chance of finding the Cape May still there. And he was there; sitting, for part of the time, at the very tip (on the terminal bud, to speak exactly) of a pointed fir. There, as elsewhere, he sang persistently, sometimes with three zees, sometimes with four, but always in an unhurried monotone. It was the simplest and most primitive kind of music, to say the best of it, - many an insect would perhaps have done as well; but somehow, with the author of it before me, I pronounced it good. A Tennessee was close by, and (what I particularly enjoyed) a tanager sat in the sun on the topmost spray of a tall white pine, blazing and singing. " This is the sixth day of the Cape May here, yet I cannot think he means to summer." So my pencil finished the day's entry.

Whatever his intentions, I could not afford to spend my whole vacation in learning them, and it was not until the afternoon of the 31st that I went again in search of him. Then he gave me an exciting chase; for, thank Fortune, a chase may be exciting 
though the bird is not a "game bird," and the man is not a gunner. At first, to be sure, the question seemed in a fair way to be quickly settled. I was hardly in the swamp before I heard the expected zee-zee. The bird was still here! But after half a dozen repetitions of the strain he fell silent; and he had not shown himself. For a full hour I paced up and down the path, within a space of forty rods, fighting mosquitoes and awake to every sound. If the bird was here, I meant to make sure of him. This was the tenth day since I had first seen him, and to find him still present would make it practically certain that he was here for the season. As for what I had already heard, - well, the notes were the Cape May's, fast enough; but if that were all, I should go away and straightway begin to question whether my ears had not deceived me. In matters of this kind, an ornithologist walks by sight.

Once, from farther up the path, I heard a voice that might be the one $I$ was listening for ; but as I hastened toward it, it developed into the homely, twisting song of a black-andwhite creeper. Heard at a sufficient dis- 
tance, this too familiar ditty loses every other one of its notes, and is easily mistaken for something else, - especially if something else happens to be on a man's mind, - as I had found to my chagrin on more than one occasion. Eye and ear both are never more liable to momentary deception than when they are most tensely alert.

Meanwhile, nothing had been heard of the Tennessee, and it became evident that he had moved on. The customary water thrush was singing at short intervals ; gayly dressed warblers darted in and out of the low evergreens, almost brushing my elbows, much to their surprise; and an olive-sided flycatcher kept up a persistent pip-pip. Something was troubling his equanimity; I had no idea what. It had been one of my special enjoyments, on this vacation trip, to renew my acquaintance with him and his humbler relative, the alder flycatcher, - the latter a commonplace body, whose emphatic quay-quéer had now become one of the commonest of sounds. The olive-side, by the bye, for all his apparent wildness, did not disdain to visit the shade trees about the hotel; and once a 
catbird, not far off, amused me by whistling a most exact reproduction of his breezy quit, quee-quée-o. If the voice had come from a treetop instead of from the depths of a low thicket, the illusion would have been complete. It is the weakness of imitators, always and everywhere, to forget one thing or another.

Still the bird I was waiting for made no sign, and finally I left the swamp and started up the road. Possibly he had gone in that direction, where I first saw him. No, he was not there, and, giving over the hunt, I turned back toward the village. Then, as I came opposite the barn again, I heard the notes in the old place, and hastened up the path. This time I was lucky, for there the bird sat on the outermost spray of a fir-tree branch. It was his most characteristic attitude. I can see him there now.

As I quitted the swamp for good, a man in a buggy was coming down the road. I put on my coat, and as he overtook me I said, "I I was putting on my coat because I felt sure you would invite me to ride." $\mathrm{He}$ smiled, and bade me get in; and though he 
had been going only to the post office, he insisted upon carrying me to the hotel, a mile beyond. Better still, we had a pleasant, humanizing talk of a kind to be serviceable to a narrow specialist, such as I seemed just now in danger of becoming. The use of tobacco was one of our topics, I remember, and the mutual duties of husbands and wives another. My host had seen a good deal of the world, it appeared, and withal was no little of a philosopher. I hope it will not sound egotistical if I say that he gave every sign of finding me a capable listener.

Once more only I saw the Cape May. His claim to be accounted a summer resident of Franconia was by this time moderately well established; but on my last spare afternoon (June 3) I could not do less than pay him a farewell visit. After looking for him in vain for twenty years (I speak as a New Englander), it seemed the part of prudence to cultivate his acquaintance while I could. At the entrance to the swamp, therefore, I put on my gloves, tied a handkerchief about my neck, and broke a stem of meadow-sweet for use as a mosquito switch. The season was 


\section{FOOTING IT IN FRANCONIA}

advancing, and field ornithology was becoming more and more a battle. I walked up the path for the usual distance (passing a few lady's-slippers, one of them pure white) without hearing the voice for which I was listening. On the return, however, I caught it, or something like it. Then, as I went in pursuit (a slow process, for caution's sake), the song turned, or seemed to turn, into something different, - louder, longer, and faster. Is that the same bird, I thought, or another? Whatever it was, it eluded my eye, and after a little the voice ceased. I retreated to the path, where I could look about me more readily and use my switch to better advantage, and anon the faint, lazy zee-zee-zee was heard again. This was the Cape May, at all events. I was sure of it. Still I wanted a look. Carefully I edged toward the sound, bending aside the branches, and all at once a bird flew into the spruce over my head. Then began again the quicker, four-syllabled zip-zip. I craned my neck and fanned away mosquitoes, all the while keeping my glass in position. A twig stirred. Still the bird sang unseen, - the 
same hurried phrase, not quite monotonous, since the pitch rose a little on the last couplet. That was a suspicious circumstance, and by this time I should not have been mightily astonished if a Blackburnian had disclosed himself. Another twig stirred. Still I could see nothing; and still I fought mosquitoes (a plague on them!) and kept my eye steady. Then the fellow did again what he had done so often, - stepped out upon a flat, horizontal branch, pretty well up, and posed there, singing and preening his feathers. I could see his yellow breast streaked with jet, his black crown, his reddish cheeks, with the yellow patch behind the rufous, and finally the big white blotch on the wing. We have lovelier birds, no doubt (the Cape May's colors are a trifle "splashy" for a nice taste, - for my own taste, I mean to say), but few, if any, whose costume is more strikingly original.

I stayed by him till my patience failed, the mosquitoes helping to wear it out; and all the while he reiterated that comparatively lively zip-zip, so very different from the listless zee-zee, which I had seen him use on pre- 
vious occasions, and had heard him use today. He was singing now, I said to myself, more like the bird at Natural Bridge, the only other one I had ever heard. It was pleasant to find that even this tenth-rate performer, one of the poorest of a poor family, had more than one tune in his music box.

My spring vacation was planned to be botanical rather than ornithological ; but we are not the masters of our own fate, though we sometimes try to think so, and my sketch is turning out a bird piece, after all. The truth is, I was in the birds' country, and it was the birds' hour. They waked me every morning, - veeries, bobolinks, vireos, sparrows, and what not; ${ }^{1}$ and as the day began,

1 I made the following list of fifty odd species heard and seen either from my windows or from the piazza: bluebird, robin, veery, hermit thrush, olive-backed thrush, chickadee, Canadian nuthatch, catbird, oven-bird, water thrush, chestnut-sided warbler, myrtle warbler, redstart, Nashville warbler, blue yellow-backed warbler, Maryland yellow-throat, warbling vireo, red-eyed vireo, cedar-bird, barn swallow, cliff swallow, sand swallow, tree swallow, goldfinch, purple finch, pine finch, red crossbill, indigobird, snowbird, song sparrow, field sparrow, chipping sparrow, vesper sparrow, white-throated sparrow, Baltimore oriole, bobolink, red-winged blackbird, crow, blue jay, kingbird, phœbe, least flycatcher, olive-sided fly- 
so it continued. I hope I was not blind to other things. I remember at this moment how rejoiced I was at coming all unexpectedly upon a little bunch of yellow lady'sslippers, - nine blossoms, I believe; rare enough and pretty enough to excite the dullest man's enthusiasm. But the fact remains, if comparisons are to be insisted upon, that a creature like the Cape May warbler has all the beauty of a flower, with the added charm of voice and motion and elusiveness. The lady's-slippers would wait for me, - unless somebody else picked them, - but the warbler could be trusted to lead me a chase, and give me, as the saying is, a run for my money. In other words, he was more interesting, and goes better into a story.

My delight in him was the greater for a consideration yet to be specified. Twelve or thirteen years ago, when a party of us were in Franconia in June, we undertook a list of the birds of the township, - a list which the scientific ornithologist of the company after-

catcher, alder flycatcher, great-crested flycatcher, wood pewee, hummingbird, chimney swift, whip-poor-will, flicker, kingfisher, black-billed cuckoo. 
ward printed. ${ }^{1}$ Now, returning to the place by myself, it became a point of honor with me to improve our work by the addition of at least a name or two. And the first candidate was the Cape May.

The second was of a widely different sort; one of my most familiar friends, though more surprising as a bird of the White Mountains than even the Cape May. I speak of the wood thrush, the most southern member of the noble group of singers to which it belongs, - the Hylocichlce, so called. It is to be regretted that we have no collective English name for them, especially as their vocal quality - by which I mean something not quite the same as musical ability - is such as to set them beyond comparison above all other birds of North America, if not of the world.

My first knowledge of this piece of good fortune was on the 29th of May. I stood on the Notch railway, intent upon a mourning warbler, noting how fond of red-cherry trees he and his fellows seemingly were, when I was startled out of measure by a

1 The Auk, vol. v. p. 151. 
wood thrush's voice from the dense maple woods above me. There was no time to look for him; and happily there was no need. He was one of the consummate artists of his race (among the members of which there is great unevenness in this regard), possessing all those unmistakable peculiarities which at once distinguish the wood thrush's song from the hermit's, with which alone a careless listener might confound it: the sudden drop to a deep contralto (the most glorious bit of vocalism to be heard in our woods), and the tinkle or spray of bell-like tones at the other extreme of the gamut. As with the Cape May, so with him, the question was, Will he stay?

Two days later I came down the track again. A hermit was in tune, and presently a wood thrush joined him. "His tone is fuller and louder than the hermit's," says my pencil, - flattered, no doubt, at finding itself in a position to speak a word of momentary positiveness touching a question of superiority long in dispute, and likely to remain in dispute while birds sing and men listen to them. A quarter of a mile farther, 
and I came to the sugar grove. Here a second bird was singing, just where I had heard him two days before. Him I sat down to enjoy; and at that moment, probably because he had seen me (and had seen me stop), he broke out with a volley of those quick, staccato, inimitably emphatic, whip-snapping calls, - pip-pip, - which are more characteristic of the species than even the song itself. So there were two male wood thrushes, and presumably two pairs, in this mountainside forest!

On the 1st of June I heard the song there again, though I was forced to wait for it; and three days afterward the story was the same. I ought to have looked for nests, but time failed me. To the best of my knowledge, the bird has never been reported before from the White Mountain region, though it is well known to breed in some parts of Canada, where I have myself seen it.

Here, then, were two notable accessions to our local catalogue. The only others (a few undoubted migrants - Wilson's black-cap warbler, the white-crowned sparrow, and the 
solitary sandpiper — being omitted) were a single meadow lark and a single yellowthroated vireo. The lark seemed to be unknown to Franconia people, and my specimen may have been only a straggler. He sang again and again on May 22, but I heard nothing from him afterward, though I passed the place often. The vireo was singing in a sugar grove on the $3 d$ of June, a date on which, accidents apart, he should certainly have been at home for the summer.

Because I have had so much to say about the Cape May warbler and the wood thrush, it is not to be assumed that I mean to set them in the first place, nor even that I had in them the highest pleasure. They surprised me, and surprise is always more talkative than simple appreciation ; but the birds that ministered most to my enjoyment were the hermit and the veery. The veery is not an every-day singer with me at home, and the hermit, for some years past, has made himself almost a stranger. I hardly know which of the two put me under the greater obligation. The veery sang almost continually, and a good veery is a singer almost out 
of competition. His voice lacks the ring of the wood thrush's and the hermit's ; it never dominates the choir; but with the coppice to itself and the listener close by, it has sometimes a quality irresistible; I do not hesitate to characterize it as angelic. Of this kind was the voice of a bird that used to sing under my Franconia window at half past three o'clock, in the silence of the morning.

The surpassing glory of the veery's song, as all lovers of American bird music may be presumed by this time to know, lies in its harmonic, double-stopping effect, - an effect, or quality, as beautiful as it is peculiar. One day, while I stood listening to it under the best of conditions, admiring the wonder. ful arpeggio (I know no less technical word for it), my pencil suddenly grew poetic. "The veery's fingers are quick on the harpstrings," it wrote. His is perfect Sunday music, - and the hermit's no less so. And in the same class I should put the simple chants of the field sparrow and the vesper. The so-called "preaching" of the red-eyed vireo is utter worldliness in the comparison. 
Happy Franconia! This year, if never before, it had all five of our New England Hylocichlæ singing in its woods : the veery and the hermit everywhere in the lower country, the wood thrush in the maple forest before mentioned, the olive-back throughout the Notch and its neighborhood, and the gray-cheek on Lafayette; a quintette hard to match, I venture to think, anywhere on the footstool. And after them-I do not say with them - were winter wrens, bobolinks, rose-breasted grosbeaks, purple finches, solitary vireos, vesper sparrows, field sparrows, white-throated sparrows, song sparrows, catbirds, robins, orioles, tanagers, and a score or two beside.

One other bright circumstance I am bound in honor to speak of, - the abundance of swallows; a state of affairs greatly unlike anything to be met with in my part of Massachusetts: cliff swallows and barn swallows in crowds, and sand martins and tree swallows by no means uncommon. But for the absence of black martins, - a famous colony of which the tourist may see at Concord, while the train waits, - here would 
have been a second quintette worthy to rank with the thrushes; the flight of one set being as beautiful, not to say as musical, as the songs of the other. As it was, the universal presence of these aerial birds was a continual delight to any man with eyes to notice it. They glorified the open valley as the thrushes glorified the woods.

We shall never again see the like of this, I fear, in our prosier Boston neighborhood. Within my time - within twenty years, indeed - barn swallows summered freely on Beacon Hill, plastering their nests against the walls of the State House and the Athenæum, and even under the busy portico of the Tremont House. I have remembrance, too, of a pair that dwelt, for one season at least, above the door of the old Ticknor mansion, at the head of Park Street. Those days are gone. Now, alas, even in the suburban districts, we may almost say that one swallow makes a summer. An evil change it is, for which not even the warblings of English sparrows will ever quite console me. Yet the present state of things, the reoccupation of Boston by the British, 
if you please to call it so, is not without its grain of compensation. It makes me fonder of "old Francony." Skeptic or man of faith, naturalist or supernaturalist, who does not like to feel that there is somewhere a "better country" than the one he lives in? 


\section{A DAY IN JUNE}

\section{THE FORENOON}

"The air that floated by me seem'd to say,

'Write! thou wilt never have a better day.'

And so I did."

KEATS.

All signs threatened a day of midsummer heat, though it was only the $2 \mathrm{~d}$ of June. Before breakfast, even, the news seemed to have got abroad; so that there was something like a dearth of music under my windows, where heretofore there had been almost a surfeit. The warbling vireo in the poplar, which had teased my ear morning after morning, getting shamelessly in the way of his betters, had for once fallen silent; unless, indeed, he had sung his stint before I woke, or had gone elsewhere to practice. The comparative stillness enabled me to hear voices from the hillside across 
the meadow, while I turned over in my mind a thought concerning the nature of those sounds - a class by themselves, some of them by no means unmusical - which are particularly enjoyable when borne to us from a distance: crow voices, the baying of hounds, cowbell tinkles, and the like. The nasal, high-pitched, penetrating call of the little Canadian nuthatch is one of the best examples of what I mean. Ank, ank : the sounds issue from the depths of trackless woods, miles and miles away as it seems, just reaching us, without a breath to spare; dying upon the very tympanum, like a spent runner who drops exhausted at the goal, touching it only with his finger tips. Yet the ear is not fretted. It makes no attempt to hear more. Ank, ank: that is the whole story, and we see the bird as plainly as if he hung from a cone at the top of the next fir tree.

"No tramping to-day," said my friends from the cottage as we met at table. They had been reading the thermometer, which is the modern equivalent for observing the wind and regarding the clouds. But my 
vacation, unlike theirs, was not an all-summer affair. It was fast running out, and there were still many things to be seen and done. Immediately after breakfast, therefore, with an umbrella and a luncheon, I started for the Notch. I would reverse the usual route, going by way of the railroad - reached by a woodland trail above "Chase's" - and returning by the highway. Of itself this is only a forenoon's jaunt, but I meant to piece it out by numerous waits _ for coolness and listening _- and sundry by-excursions, especially by a search for Selkirk's violet and an hour or two on Bald Mountain. If the black flies and the mosquitoes would let me choose my own gait, I would risk the danger of sunstroke.

As I come out upon the grassy plain, after the first bit of sharp ascent, a pleasant breeze is stirring, and with the umbrella over my head, and a halt as often as the shade of a tree, the sight of a flower, or the sound of music invites me, I go on with great comfort. Now I am detained by a close bed of dwarf cornel, every face looking straight upward, the waxen white "flowers" 
inclosing each a bunch of dark pin-points. Now a lovely clear-winged moth hovers over a dandelion head; and a pleasing sight it is, to see his transparent wings beating themselves into a haze about his brown body. And now, by way of contrast, one of our tiny sky-blue butterflies rises from the ground and with a pretty unsteadiness flits carelessly before me, twinkling over the sand.

A bluebird drops into the white birch under which I am standing, and lets fall a few notes of his contralto warble. A delicious voice. For purity and a certain affectionateness it would be hard to name its superior. A vesper sparrow sings from the grass land; and from the woods beyond a jay is screaming. His, by the bye, is another of the voices that are bettered by distance, although, for my own part, I like the ring of it, near or far. Now a song sparrow breaks out in his breezy, characteristically abrupt manner. He is a bird with fine gifts of cheeriness and versatility; but when he sets himself against the vesper, as now, it is like prose against poetry, plain talk against 
music. So it seems to me at this moment, I mean to say. At another time, in another mood, I might tone down the comparison, though I could never say less than that the vesper is my favorite. His gifts are sweetness and perfection.

So I cross the level fields to Chase's, where I stand a few minutes before the little frontyard flower-garden, always with many pretty things in it. One of those natural gardeners, the good woman must be, who have a knack of making plants blossom. And just beyond, in the shelter of the first tree, I stop again to take off my hat, put down my umbrella, and speak coaxingly to a suspicious pointer (being a friend of all dogs except surly ones), which after much backing and filling gets his cool nose into my palm. We are on excellent terms, I flatter myself, but at that moment some notion strikes me and I take out my notebook and pencil. Instantly he starts away and sets up a furious bark, looking first at me, then toward the house, circling about me all the while, at a rod's distance, in a quiver of excitement. "Help! help!" he cries. "Here's a villain 
of some sort. I've never seen the like. A spy at the very least." And though he quiets down when I put up the book, there is no more friendliness for this time. Man writing, as Carlyle would have said, is a doubtful character.

Another stage, to the edge of the woods, and I rest again, the breeze encouraging me. A second bluebird is caroling. Every additional one is cause for thankfulness. Imagine a place where bluebirds should be as thick as English sparrows are in our American cities! Imagine heaven! A crested flycatcher screams, an olive-side calls pip, pip, a robin cackles, an oven-bird recites his piece with schoolboy emphasis, an alder flycatcher queeps, and a vesper sparrow sings. And at the end, as if for good measure, a Maryland yellow-throat adds his witchery, witchery. The breeze comes to me over broad beds of hay-scented fern, and at my feet are bunchberry blossoms and the white star-flower. At this moment, nevertheless, the cooling, insect-dispersing wind is better than all things else. Such is one effect of hot weather, setting comfort above poetry. 
I leave the wind behind, and take my way into the wood, where there is nothing in particular to delay me except an occasional windfall, which must be clambered over or beaten about. Half an hour, more or less, of lazy traveling, and I come out upon the railroad at the big sugar-maple grove. This is one of the sights of the country in the brightleaf season, say the first week of October; something, I have never concluded what, giving to its colors a most remarkable depth and richness. Putting times together, I must have spent hours in admiring it, now from different points on the Butter Hill round, now from Bald Mountain. At present every leaf of it is freshly green, and somewhere within it dwells a wood thrush, for whose golden voice I sit down in the shade to listen. $\mathrm{He}$ is in no haste, and no more am I. Let him take his time. Other birds also are a little under the weather, as it appears; but the silence cannot last. A scarlet tanager's voice is the first to break it. High as the temperature is, he is still hoarse. And so is the black-throated blue warbler that follows him. A pine siskin passes orer- 
head on some errand, announcing himself as he goes. There is no need for him to speak twice. Then come three warblers, - a Nashville, a magnolia, and a blue yellow-back; and after them a piece of larger game, a smallish hawk. He breaks out of the dense wood behind me, perches for half a minute in an open maple, where I can see that he has prey of some kind in his talons, and then, taking wing, ascends in circles into the sky, and so disappears. That is locomotion of a sort to make a man and his umbrella envious.

A rose-breasted grosbeak, invisible (but I can see him), is warbling not far off. He has taken the tanager's tune - which is the robin's as well - and smoothed it and smoothed it, and sweetened it and sweetened it, till it is smoother than oil and sweeter than honey. I admire it for what it is, a miracle of mellifluency; if you call it perfect, I can only acquiesce; but I cannot say that it stirs or kindles me. Perhaps I haven't a sweet ear. And hark! the wood thrush gives voice : only a few strains, but enough to show him still present. Now I am free 
to trudge along up the railroad track, pondering as I go upon the old question why railway sleepers are always too far apart for one step and not far enough for two. At short intervals I pause at the sound of a mourning warbler's brief song, pretty in itself, and noticeable for its trick of a rolled $r$. Some of the birds add a concluding measure of quick notes, like wit, wit, wit. It is long since I have seen so many at once. In truth, I have never seen so many except on one occasion, on the side of Mount Washington. That was ten years ago. One a year, on the average, shows itself to me during the spring passage — none in autumn. Well I remember my first one. Twenty years have elapsed since that late May morning, but I could go to the very spot, I think, though I have not been near it for more than half that time. A good thing it is that we can still enjoy the good things of past years, or of what we call past years.

And a good thing is a railroad, though the sleepers be spaced on purpose for a foot passenger's discomfort. Without this one, over which at this early date no trains are 


\section{A DAY IN JUNE}

rumning, I should hardly be traversing these miles of rough mountain country on a day of tropical sultriness. The clear line of the track gives me not only passage and a breeze, but an opening into the sky, and at least twice as many bird sights and bird sounds as the unbroken forest would furnish. ${ }^{1}$ I drink at the section men's well - an ice-cold spring inclosed in a bottomless barrelcross the brook which, gloriously alive and beautiful, comes dashing over its boulders down the White-cross Ravine, fifty feet below me as I guess, and stop in the burning on the other side to listen for woodpeckers and brown creepers. The latter are strangely rare hereabout, and this seems an ideal spot in which to look for them. So I cannot help thinking as I see from how many of the trunks - burned to death and left standing

1 I was once walking over these same miles of sleepers with a bird-loving man, when he recalled a reminiscence of his boyhood. One of his teachers was remarking upon the need of seeking things in their appropriate places. "Now if you wanted to see birds," he said, by way of illustration, "you would n't go to a railroad track." "Which is the very place we do go to," my companion added. 
- the bark has warped in long, loose flakes, as if to provide nesting sites for a whole colony of creepers. But the birds are not here; or, if they are, they do not mean that an inquisitive stranger shall know it. An olivesided flycatcher calls, rather far off, making me suspicious for an instant of a red crossbill, and a white-throated sparrow whistles out of the gulch below me; but I listen in vain for the quick tseep which would put an eighty-seventh name into my vacation catalogue.

Here is the round-leaved violet, one palebright, shy blossom. How pleased I am to see it! Hobble-bush and wild red cherry are still in bloom. White Mountain dogwood, we might almost call the hobble-bush; so well it fills the place, in flowering time, of Cornus florida in the Alleghanies. In the twilight of the woods, as in the darkness of evening, no color shows so far as white; which, for aught I know, may be one of the reasons why, relatively speaking, white flowers are so much more common in the forest than in the open country. In my eyes, nevertheless, the leaves of the hobble-bush 
- leaves and leaf-buds - are, if anything, prettier than the blossoms. Such beauty of shape, such expansiveness, such elegance of crimpling, and such exceeding richness of hue, whether in youth or age! If the bush refuses transplantation, as I have read that it does, I am glad of it. My sympathies are with all things, plants, animals, and men, that insist upon their native freedom, in their native country, with a touch, or more than a touch, of native savagery. Civilization is well enough, within limits; but why be in haste to have all the world a garden? It will be some time yet, I hope, before every valley is exalted.

With progress of this industriously indolent sort it is nearly noon by the time I turn into the footpath that leads down to Echo Lake. Here the air is full of toad voices; a chorus of long-drawn trills in the shrillest of musical tones. If the creatures (the sandy shore and its immediate shallows are thick with them) are attempting to set up an echo, they meet with no success. At all events I hear no response, though the fault may easily be in my hearing, insusceptible as 
it is to vibrations above a certain pitch of fineness. What ethereal music it would be, an echo of toad trills from the grand sounding-board of Eagle Cliff! In the density of my ignorance I am surprised to find such numbers of these humble, half-domesticated, garden-loving batrachians congregated here in the wilderness. If the day were less midsummery, and were not already mortgaged to other plans, I would go down to Profile Lake to see whether the same thing is going on there. I should have looked upon these lovely sheets of mountain water as spawningplaces for trout. But toads! - that seems another matter. If I am surprised at their presence, however, they seem equally so at mine. And who knows? They were here first. Perhaps I am the intruder. I wish them no harm in any case. If black flies form any considerable part of their diet, they could not multiply too rapidly, though every note of every trill were good for a polliwog, and every polliwog should grow into the portliest of toads. 


\section{THE AFTERNOON}

I spoke a little warmly, perhaps, at the end of the forenoon chapter. Echo Lake, at the foot of it, is one of the places where I love best to linger, and to-dlay it was more attractive even than usual; the air of the clearest, the sun bright, the mountain woods all in young leaf, the water shining. But the black flies, which had left me undisturbed on the railroad, though I sat still by the half hour, once I reached the lake would allow me no rest.

It was twelve days since my first visit. The snow was gone, and the trailing arbutus had dropped its last blossoms; but both kinds of shadbush, standing in the hollow where a snow-bank had lain ten days ago, were still in fresh bloom. Pink lady's-slippers were common (more buds than blossoms as yet), and the pink rhodora also; with gold-thread, star-flower, dwarf cornel, housonia, and the painted trillium. Chokeberry bushes were topped with handsome clusters of round, purplish buds.

The brightest and prettiest thing here, 
however, was not a flower, but a bird; a Blackburnian warbler fluttering along before me in the low bushes - an extraordinary act of grace on the part of this haunter of treetops - as if on purpose to show himself. He was worth showing. His throat was like a jewel. A bay-breast, always deserving of notice, was singing among the evergreens near by. So I believed, but the flies were so hot after me that I made no attempt to assure myself. I was fairly chased away from the water-side. One place after another I fled to, seeking one where the breeze should rid me of my tormentors, till at last, in desperation, I took to the piazza of the little shop - now unoccupied - at which the summer tourist buys birch-bark souvenirs, with ginger-beer, perhaps, and other potables. There I finished my luncheon, still having a skirmish with the enemy's scouts now and then, but thankful to be out of the thick of the battle. The rippling lake shone before me, a few swifts were shooting to and fro above it, but for the time my enjoyment of all such things was gone. That half hour of black-fly persecution had dissi- 
pated the happy mood in which the forenoon had been passed, and there was no recovering it by force of will. A military man would have said, perhaps, that I had lost my morale. Something had happened to me, call it what you will. But if one string was broken, my bow had another. Quiet meditation being impossible, I was all the readier to go in search of Selkirk's violet, the possible finding of which was one of the motives that had brought me into the mountains thus early. To look for flowers is not a question of mood, but of patience. To look at them, so as to feel their beauty and meaning, is another business, not to be conducted successfully while poisonous insects are fretting one's temper to madness.

If I went about this botanical errand doubtingly, let the reader hold me excused. $\mathrm{He}$ has heard of a needle in a haystack. The ease of my violets was similar. The one man who had seen them was now dead. Years before, he had pointed out to me casually (or like a dunce I had heard him casually) the place where he was accustomed to leave the road in going after them - which 
was always long before my arrival. This place I believed that I remembered within perhaps half a mile. My only resource, therefore, was to plunge into the forest, practically endless on its further side, and as well as I could, in an hour or so, look the land over for that distance. Success would be a piece of almost incredible luck, no doubt; but what then? I was here, the hour was to spare, and the woods were worth a visit, violets or no violets. So I plunged in, and, following the general course of the road, swept the ground right and left with my eye, turning this way and that as boulders and tangles impeded my steps, or as the sight of something like violet leaves attracted me.

Well, for good or ill, it is a short story. There were plenty of violets, but all of the common white sort, and when I emerged into the road again my hands were empty. "Small," "rare," says the Manual. My failure was not ignominious, - or I would keep it to myself, - and I count upon trying again another season. And one thing I had found : my peace of mind. Subjectively, as 
we say, my hunt had prospered. Now I could climb Bald Mountain with good hope of an hour or two of serene enjoyment at the summit.

The climb is short, though the upper half of it is steep enough to merit the name, and the "mountain" (it will pardon me the quotation marks) is no more than a point of rocks, an outlying spur of Lafayette. Its attractiveness is due not to its altitude, but to the exceptional felicity of its situation; commanding the lake and the Notch, and the broad Franconia Valley, together with a splendid panorama of broken country and mountain forest; and over all, close at hand, the solemn, bare peak of Lafayette.

I took my time for the ascent (blessed be all-day jaunts, say I), minding the mossy boulders, the ferm-beds, and the trees (many of them old friends of mine-it is more than twenty years since I began going up and down here), and especially the violets. It was surprising, not to say amusing, now that I had violets in my eye, how ubiquitous the little blanda had suddenly become. Almost it might be said that there was nothing 
else in the whole forest. So true it is that seeing or not seeing is mostly a matter of prepossession. As for the birds, this was their hour of after-dinner silence. I recall only a golden-crowned kinglet zeeing among the low evergreens about the cone. He was the first one of my whole vacation trip, and slipped at once into the eighty-seventh place in my catalogue, the place I had tried so hard to induce the brown creeper to take possession of two hours before. Creeper or kinglet, it was all one to me, though the kinglet is the handsomer of the two, and much the less prosaic in his dietary methods. In fact, now that the subject suggests itself, the two birds present a really striking contrast: one so preternaturally quick and so continually in motion, the other so comparatively lethargic. Every one to his trade. Let the creeper stick to his bark. Quick or slow, he should still have been Number 88, and thrice welcome, if he would have given me half an excuse for counting him. As things were, he kept out of my reckoning to the end.

"This is the best thing I have had yet." 
So I said to myself as I turned to look about me at the summit. It was only half past two, the day was gloriously fair, the breeze not too strong, yet ample for creature comforts, - coolness and freedom, - and the place all my own. If I had missed Selkirk's violet, I had found his solitude. The joists of the little open summer-house were scrawled thickly with names and initials, but the scribblers and carvers had gone with last year's birds. I might sing or shout, and there would be none to hear me. But I did neither. I was glad to be still and look.

There lay Echo Lake, shimmering in the sun. Beyond was the hotel, its windows still boarded for winter, and on either side of it rose the mountain walls. The White Cross still kept something of its shape on Lafayette, the only snow left in sight, though almost the whole peak had been white ten days before. The cross itself must be fast going. With my glass I could see the water pouring from it in a flood. And how plainly I could follow the trail up the rocky cone of the mountain! Those were good days when I climbed it, lifting myself step by step up 
that long, steep, boulder-covered slope. I should love to be there now. I wonder what flowers are already in bloom. It must be too early for the diapensia and the Greenland sandwort, I imagine. Yet I am not sure. Mountain flowers are quick to answer when the sun speaks to them. Thousands of years they have been learning to make the most of a brief season. Plants of the same species bloom earlier here than in level Massachusetts. After all, alpine plants, hurried and harried as they are, true children of poverty, have perhaps the best of it. "Blessed are ye poor " may have been spoken to them also. Hardy mountaineers, blossoming in the very face of heaven, with no earthly admirers except the butterflies. I remember the splendors of the Lapland azalea in middle June, with rocks and snow for neighbors. So it will be this year, for Wisdom never faileth. I look and look, till almost I am there on the heights, my feet standing on a carpet of blooming willows and birches, and the world, like another carpet, outspread below.

But there is much else to delight me. 
Even here, so far below the crest of Lafayette, I am above the world. Yonder is one of my pair of deserted farms. Good hours I have had in them. Beyond is the Chase clearing, and still beyond, over another tract of woods, are the pasture lands along the road to "Mears's." Then comes the line of the Bethlehem road, marked by a house at long intervals - and thankful am I for the length of them. There I see my house; one of several that I have picked out for purchase, at one time and another, but have never come to the point of paying for, still less of occupying. When my friends and I have wandered irresponsibly about this country it has pleased us to be like children, and play the old game of make-believe. Some of the farmers would be astonished to know how many times their houses have been sold over their heads, and they never the wiser. Further away, a little to the right, I see the pretty farms - romantic farms, I mean, attractive to outsiders - of which I have so often taken my share of the crop from Mount Agassiz, at the base of which they nestle. To the left of all this are the 
village of Franconia and the group of Sugar Hill hotels, with the Landaff Valley (how green it is!) below them in the middle distance. Nearer still is the Franconia Valley, with the Tucker Brook alders, and far down toward Littleton bright reaches of Gale River.

All this fills me with exquisite pleasure. But longer than at anything else I look at the mountain forest just below me. So soft and bright this world of treetops all newly green! I have no thoughts about it; there is nothing to say; but the feeling it gives me is like what I imagine of heaven itself. I can only look and be happy.

About me are stunted, faded spruces, with here and there among them a balsamfir, wonderfully vivid and fresh in the comparison; and after a time I discover that the short upper branches of the spruces have put forth new cones, soft to the touch as yet, and of a delicate, purplish color, the tint varying greatly, whether from difference of age or for other reasons I cannot presume to say. In this low wood, somewhere near by, a blackpoll warbler, not long 
from South America, I suppose, is lisping softly to himself. A myrtle warbler, less recently come, and from a less distance, has taken possession of a dead treetop, hardly higher than a man's head, from which he makes an occasional sally after a passing insect. Between whiles he sings. Once I heard a snowbird, as I thought; but it was only the myrtle warbler when I came to look. An oven-bird shoots into the air out of the forest below for a burst of aerial afternoon music. I heard the preluding strain, and, glancing up, eaught him at once, the sunlight happening to strike him perfectly. All the morning he has been speaking prose; now he is a poet; a division of the day from which the rest of us might take a lesson. But for his afternoon rôle he needs a name. "Oven-bird" goes somewhat heavily in a lyric:-

"Hark! hark! the oven-bird at heaven's gate sings" you would hardly recognize that for Shakespeare.

As I shift my position, trying one after another of the seats which the rocks offer 
for my convenience, I notice that the threetoothed five-finger - a mountain lover, if there ever was one - is in bud, and the blueberry in blossom. The myrtle warbler sings by the hour, a soft, dreamy trill, a sound of pure contentment; and two redeyed vireos, one here, one there, preach with equal persistency. They have taken the same text, I think, and it might have been made for them: "Precept upon precept, precept upon precept; line upon line, line upon line; here a little and there a little." Right or wrong, the warbler's lullaby is more to my taste than the vireos' exhortation. A magnolia warbler, out of sight among the evergreens, is making an afternoon of it likewise. His song is a mere nothing; hardly to be called a "line;" but if all the people who have nothing extraordinary to say were to hold their peace, what would ears be good for? The race might become deaf, as races of fish have gone blind through living in caverns.

These are exactly such birds as one might have expected to find here. And the same may be said of a Swainson thrush and a 
pine siskin. A black-billed cuckoo and a Maryland yellow-throat, on the other hand, the yellow-throat especially, seem less in place. What can have brought the latter to this dry, rocky hilltop is more than I can imagine. A big black-and-yellow butterfly (Turnus) goes sailing high overhead, borne on the wind. For so unsteady a steersman he is a bold mariner. A second look at him, and he is out of sight. Common as he is, he is one of my perennial admirations. The peak of Lafayette is no more a miracle. All the flowers up there know him.

Now it is time to go. I have been here an hour and a half, and am determined to have no hurrying on the way homeward, over the old Notch road. Let the day be all alike, a day of leisure and of dreams. A last look about me, a few rods of picking my steep course downward over the rocks at the very top, and $I$ am in the woods. Here, "my distance and horizon gone," I please myself with looking at bits of the world's beauty; especially at sprays of young leaves, breaking a twig here and a twig there to carry in my hand; a spray of 
budded mountain maple or of yellow birch. Texture, color, shape, veining and folding - all is a piece of Nature's perfect work. No less beautiful - I stop again and again before a bed of them - are the dainty branching beech-ferns. There is no telling how pretty they are on their slender shining stems. And all the way I am taking leave of the road. I may never see it again. "Good-by, old friend," I say ; and the trees and the brook seem to answer me, "Goodby." 


\title{
BERRY-TIME FELICITIES
}

\author{
"A nice and subtle happiness, I see, \\ Thou to thyself proposest."
}

MiltoN.

ONCE more I am in old Franconia, and in a new season. With all my visits to the New Hampshire mountains, I have never seen them before in August. I came on the last day of July, - a sweltering journey. That night it rained a little, hardly enough to lay the dust, which is deep in all these valley roads, and the next morning at breakfast time the mercury marked fifty-seven degrees. All day it was cool, and at night we sat before a fire of logs in the big chimney. The day was really a wonder of clearness, as well as of pleasant autumnal temperature; an exceptional mercy, calling for exceptional acknowledgment.

After breakfast I took the Bethlehem road at the slowest pace. The last time I 
had traveled it was in May. Then every tree had its bird, and every bird a voice. Now it was August - the year no longer young, and the birds no longer a choir. And when birds are neither in tune nor in flocks, it is almost as if they were absent altogether. It seemed to me, when I had walked a mile, that I had never seen Franconia so deserted.

An alder flycatcher was calling from a larch swamp; a white-throated sparrow whistled now and then in the distance; and from still farther away came the leisurely, widely spaced measures of a hermit thrush. When he sings there is no great need of a chorus; the forest has found a tongue; but I could have wished him nearer. A solitary vireo, close at hand, regaled me with a sweet, low chatter, more musical twice over than much that goes by the name of singing, the solitary being one of the comparatively few birds that do not know how to be unmusical, - and a sapsucker, a noisy fellow gone silent, flew past my head and alighted against a telegraph pole.

Wild red cherries (Prunus Pennsylva- 
nica) were ripe, or nearly so ; very bright and handsome on their long, slender stems, as I stood under the tree and looked up. With the sun above them they became fairly translucent, the shape of the stone showing. They were pretty small, I thought, and would never take a prize at any horticultural fair; I needed more than one in the mouth at once when I tested their quality; but a robin, who had been doing the same thing, seemed reluctant to finish, and surely robins are competent judges in matters of this kind. My own want of appreciation was probably due to some pampered coarseness of taste.

An orchid, with one leaf and a spike of minute greenish flowers, attracted notice, not for any showy attributes, but as a plant I did not know. Adder's mouth, it proved to be; or, to give it all the Grecian Latinity that belongs to it, Microstylis ophioglossoides. How astonished it would be to hear that mouth-confounding name applied to its modest little self; as much astonished, perhaps, as we should be, who are not modest, though we may be greenish, if we heard 
some of the more interesting titles that are applied to us, all in honest vernacular, behind our backs. This year's goldthread leaves gave me more pleasure than most blossoms could have done; lustrous, elegantly shaped, and in threes. Threes are prettier than fours, I said to myself, as I looked at some four-leaved specimens of dwarf cornel growing on the same bank. The comparison was hardly decisive, it is true, since the cornus leaves lacked the goldthread's shapeliness and brilliancy; but I believe in the grace of the odd number. With trifles like these I was entertaining the time when a man on a buckboard reined in his horse and invited me to ride. $\mathrm{He}$ was going down the Gale River road a piece, he said, and as this was my course also I thankfully accepted the lift. I would go farther than I had intended, and would spend the forenoon in loitering back. My host had two or three tin pails between his feet, and I was not surprised when he told me that he was "going berrying." What did surprise me was to find, fifteen minutes later, when I got on my legs again, that 
with no such conscious purpose, and with no tin pail, I had myself come out on the same errand. "It is not in man that walketh to direct his steps."

The simple truth was that the raspberries would not take no for an answer. If I passed one clump of bushes, another waylaid me. " Raspberries, all ripe," they said. It was not quite true : that would have been a misfortune unspeakable; but the ripe ones were enough. Softly they dropped into the fingers - softly in spite of their asperous name - and sweetly, three or four together for goodness' sake, they melted upon the tongue. They were so many that a man could have his pick, taking only those of a deep color (ten minutes of experience would teach him the precise shade) and a worthy plumpness, passing a bushel to select a gill.

No raspberry should be pulled upon ever so little; it should fall at the touch; and the teeth should have nothing to do with it, more than with honey or cream. So I meditated, and so with all daintiness I practiced, finishing my banquet again and again as a fresh cluster beguiled me; for raspberry-eat- 
ing, like woman's work, is never done. If the apple in Eden was as pleasant to the eyes and half as good to eat, then I have no reflections to east upon the mistress of the garden. In fact, it seems to me not unlikely that the Edenic apple may have been nothing more nor less than a Franconian raspberry. Small wonder, say I, that one taste of its "sciential sap" "gave elocution to the mute."

So I came up out of the Gale River woods into the bushy lane - a step or two and a mouthful of berries - and thence into the level grassy field by the grove of pines; a favorite place, with a world of mountains in sight-Moosilauke, Kinsman, Cannon, Lafayette, Haystack, the Twins, and the whole Mount Washington range. A pile of timbers, the bones of an old barn, offered me a seat, and there I rested, facing the mountains, while a company of merry barn swallows, loquacious as ever, went skimming. over the grass. Moving clouds dappled the mountain-sides with shadows, the sun was good, a rare thing in August, and I was happy. 
This lasted for a matter of half an hour. Then a sound of wheels caused me to turn my head. Yes, a pair of gray horses and a covered carriage, with a white net protruding behind, - an entomological flag well known to all Franconia dwellers in summer time, one of the institutions of the valley. A hand was waved, and in another minute I was being carried toward Bethlehem, all my pedestrian plans forgotten. I was becoming that disreputable thing, an opportunist. But what then! As I remarked just now, "It is not in man that walketh to direct his steps." In vacation days the wisest of us may go with the wind.

A pile of decaying logs by the roadside soon tempted the insect collector to order a halt. She was brought up, as I have heard her say regretfully, on the stern New England doctrine that time once past never returns, and she is still true to her training. We stripped the bark from log after log, but uncovered nothing worth while (such beetles as the unprofessional assistant turned up being damned without hesitation as "common") except two little mouse-col- 
ored, red-bellied snakes, each with two or three spots on the back of its head. One of these pretty creatures the collector proceeded to mesmerize by rubbing its crown gently with a stick. "See! he enjoys it," she said; and if thrusting out the tongue is a sign of enjoyment, no doubt he was in something like an ecstasy. Storeria occipitomaculata, the books call him. Short snakes, like small orchids, are well pieced out with Latinity. I would not disturb the savor of raspberries by trying just then to put my tongue round that specific designation, though it goes trippingly enough with a little practice, and is plain enough in its meaning. One did not need to be a scholar, or to look twice at the snake, to see that its occiput was maculated. At the top of the hill — for we took the first turn to the left _ "creation widened," and we had before us a magnificent prospect westward, with many peaks of the Green Mountains beyond the valley. Atmosphere so transparent as to-day's was not made for nothing. Insects and even raspberries were for the moment out of mind. There was glory everywhere. We looked at it, but 
when we talked it was mostly of trifles: the bindweed, the goldenrod, a passing butterfly, a sparrow. Those who are really happy are often pleased to speak of matters indifferent. Sometimes I think it is those who only wish to be happy who deal in superlatives and exclamations.

One thing I was especially glad to see: the big pastures on the Wallace Hill road full of hardhack bloom. Many times, in September and October, I had stopped to gaze upon those acres on acres of brown spires; now I beheld them pink. It was really a sight, a sea of color. If cattle would eat Spircea tomentosa, the fields would be as good as gold mines. So I thought. I thought, too, what an ocean of " herb tea" might be concocted from those millions and millions of leafy stalks. The idea was too much for me ; imagination was near to being drowned in a sea of its own creating; and I was relieved when we left the rosy wilderness behind us, and came to the famous clump of pear-leaved willow ( $S a$ lix balsamifera) near the edge of the wood. This I must get over the fence and put my 
hand on, just for old times' sake. A man may take it as one of the less uncomfortable indications of increasing age when he loves to do things simply because he used to do them, or has done them in remembered company. In that respect I humor myself. If there is anything good in the multiplying of years, by all means let me have it. And so I wore the willow.

On the way down the steep hill through the forest my friends pointed out a maple tree which a pileated woodpecker had riddled at a tremendous rate. The trunk contained the pupæ of wasps (they were not strictly wasps, the entomologist was careful to explain, but were always called so by "common people"), and no doubt it was these that the woodpecker had been after. He had gone clean to the heart of the trunk, now on this side, now on that. Chips by the shovelful covered the ground. The big, redcrested fellow must love wasp pupæ almost as well as some people love raspberries. Green leaves, a scanty covering, were still on the tree, but its days were numbered. Who could have foreseen that the stings of 
insects would bring such destruction? Misfortunes never come singly. After the wasps the woodpecker. "Which things are an allegory."

One of my pleasures of the milder sort was to sit on the piazza before breakfast (the lateness of the White Mountain breakfast hour being one of a walking man's displeasures) and watch the two morning processions: one of tall mill cans to and from the creamery, - an institution which any country-born New Englander may be glad to think of, for the comfort it has brought to New England farmers' wives; the other of boys, each with a tin pail, on their way to serve as caddies at the new Profile House golf links. This latter procession I had never seen till the present year. Half the boys of the village, from seven or eight to fifteen or sixteen years old, seemed to have joined it; some on bicycles, some in buggies, some on foot, none on horseback - a striking omission in the eyes of any one who has ever lived or visited at the South.

Franconia boys, I have noticed, have a 
cheerful, businesslike, independent way with them, neither bashful nor overbold, and it was gratifying to see them so quick to improve a new and not unamusing method of turning a penny. Work that has to do with a game is no more than half work, though the game be played by somebody else; and some of the boys, it was to be remarked, carried golf sticks of their own. Trust a Yankee lad to combine business and pleasure. One such I heard of, who was already planning how to invest his prospective capital.

"Mamma," he said, " can't I spend part of my money for a fishing-rod ?"

"But, my dear," said his mother, "you know it was agreed that the first of it should go for clothes."

"Yes, mamma, but a boy can get along without clothes; and I 've never had any fishing-rod but a peeled stick."

It sounds like a fairy tale, but it is strictly true, that a famous angler, just then disabled from practicing his art, overheard - or was told of, I am not certain which - this heartwarming confession of faith, and at once 
said, "My boy, I will give you a fishing-rod." And so he did, and a silk line with it. A boy who could get on without clothes, but must have the wherewithal to go a-fishing, was a boy with a sense of values, a philosopher in the bud, and merited encouragement.

While I watched these industrial processions ("Gidap, Charlie! Gidap!" says a cheery voice down the road), I listened to the few singers whose morning music could still be counted upon: one or two song sparrows, a field sparrow, an indigo-bird (as true a lover of August as of feathery larch tops), a red-eyed vireo, and a distant hermit thrush. Almost always a score or two of social barn swallows were near by, dotting the telegraph wires, or, if the morning was cold, dropping in bunches of twos and threes into the thick foliage of young elms. In the trees, on the wires, or in the air, they were sure to keep up a comfortable-sounding chorus of squeaky twitters. The barn swallow is born a gossip; or perhaps we should say a talking sage - a Socrates, if you will, or a Samuel Johnson. Now and then - too 
rarely - a vesper sparrow sang a single strain, or a far-away white-throat gave voice across the meadow; and once a passing humming-bird, a good singer with his wings, stopped to probe the monk's-hood blossoms in the garden patch. The best that can be said of the matter is that for birds the season was neither one thing nor another. Lovers of field ornithology should come to the mountains earlier or later, leaving August to the crowd of common tourists, who love nature, of course (who does n't in these days?), but only in the general; who believe with Walt Whitman - since it is not necessary to read a poet in order to share his opinions - that " you must not know too much or be too precise or scientific about birds and trees and flowers and water-craft; a certain free margin, and even vagueness even ignorance, credulity - helping your enjoyment of these things."

Such a credulous enjoyer of beauty I knew of, a few years ago, a summer dweller at a mountain hotel closely shut in by the forest on all sides, with no grass near it except a scanty plot of shaven lawn. Well, 
this good larly, an honest appreciator of things wild, after the Whitman manner, being in the company of a man known to be interested in matters ornithological, broke out upon him, -

"Oh, Mr. —, I do so enjoy the birds! I sit at my window and listen to the meadow larks by the hour."

The gentleman was not adroit (I am not speaking of myself, let me say). Perhaps he was more ornithologist than man of the world. Such a thing may happen. At any rate he failed to command himself.

"Meadow larks!" he answered, knowing there was no bird of that kind within ten miles of the spot in question.

"Well," said his fair interlocutor, "they are either meadow larks or song sparrows."

Such nature lovers, I say, may properly enough come to the mountains in August. As for bird students, who, not being poets, are in no danger of knowing "too much," if they can come but once a year, let them by all means choose a birdier season.

For myself, though my present mood was rather Whitmanian than scientific, I did de- 
vote one forenoon to what might be called an ornithological errand: I went up to the worn-out fields at the end of the Coal Hill road, to see whether by any chance a pair of horned larks might be summering there, as I had heard of a pair's doing eight or ten years ago. Even this jaunt, however, ran into - I will not say degenerated into something like a berry-picking excursion. Raspberries and blueberries so thick as to color the roadside, mile after mile, are a delightful temptation to a natural man whose home is in a closely settled district where every edible berry that turns red (actual ripeness being out of the question) finds a small boy beside the bush ready to pick it. I succumbed at once. In fact, I succumbed too soon. The road was long, and the berries grew fatter and riper, or so I thought, as I proceeded. It was a real tragedy. Does anything in my reader's experience tell him what I mean? If so, I am sure of his sympathy. If not, - well, in that case he has my sympathy. Perhaps he has once in his life seen a small boy who, at table, not suspecting what was in store for him, 
ate so much of an ordinary dinner that out of sheer physical necessity he was compelled to forego his favorite dessert. Alas, and alas! A wasted appetite is like wasted time, a loss irreparable. You may have another, no doubt, on another day, but never the one you sated upon inferior fruit.

Why should berries be so many, and a man's digestive capacity so near to nothing? The very bushes reproached me; like a jealous housewife who finds her choicest dainties discarded on the plate. "We have piped unto you and ye have not danced," they seemed to mutter. I grew shame-faced and looked the other way: at the splendid rosettes of red bunchberries; at a bush full of red (another red) mountain-holly berries, red with a most exquisite purplish bloom, the handsomest berries in the world, I am ready to believe. Or I stopped to consider a cluster of varnished baneberries, or a few modest, drooping, leaf-hidden jewels of the twisted stalk. In truth, and in short, it was berry-time in Franconia. What a strait a man would have been in if all kinds had been humanly edible! 
With all the rest there was no passing the strangely blue bear-plums, as Northern people call the fruit of clintonia. A strange blue, I say. Left to myself I should never have found a word for it; but by good luck I raised the question with a man who, as I now suppose, is probably the only person in the world who could have told me what I needed to know. He is an authority upon pottery and porcelain, and he answered on the instant, though I cannot hope to quote him exactly, that the color was that of the Ming dynasty. Every Chinese dynasty, I think he said, has a color of its own for its pottery. When the founder of the Ming dynasty was asked of what shade he would have the royal dinner set, he replied: "Let it be that of the sky after rain." And so it was the color of Franconia bear-plums. Which strikes me as a circumstance very much to the Ming dynasty's credit.

In a lonely stretch of the road, with a cattle pasture on one side and a wood on the other, where tall grass in full flower stood between the horse track and the wheel rut (this was a good berrying place, also, had I 
been equal to my opportunity), I stood still to enjoy the music of a hermit thrush, which happened to be at just the right distance. A holy voice it was, singing a psalm, measure responding to measure out of the same golden throat. I tried to fit words to it. "Oh," it began, but for the remainder of the strophe there were no syllables in our heavy, consonant-weighted English tongue. It might be Spanish, I thought - musical vowels with $l$ 's and $d$ 's holding them together. I remembered the reputed saying of Charles V., that Spanish is the language of the gods, and was ready to add, "and of hermit thrushes." But perhaps this was only a fancy. One thing was certain : the bird sang in Spanish or in something better. If a man could eat raspberries as long as he can listen to sweet sounds!

Before the last house there was a brilliant show of poppies, and beyond, at the limit of the clearing, an enormous bean-field. Poppies and beans! Poetry and prose! Something to look at and something to eat. Such is the texture of human life. For my part, I call it a felicitous combination. Here, only 
a little while ago, the man of the house and of the beanfield - had come face to face with a most handsome, long-antlered deer, which stamped at him till the two, man and deer, were at close quarters, and then made off into the woods. Somewhere here, also, the entomological collector had within a week or two found a beetle of a kind that had never been "taken" before except in Arizona! But though I beat the grass over from end to end, there was no sign of horned larks. Ornithology was out of date, as was more and more apparent.

My homeward walk, with the cold wind cutting my face, took on the complexion of a retreat. I could hardly walk fast enough, though here and there a clump of virginal raspberry vines still detained me briefly. It is amazing how frigid August can be when the mood takes it. A farmer was mowing with his winter coat buttoned to the chin. I looked at him with envy. For my own part I should have been glad of an overcoat; and that afternoon, when I went out to drive, I wore one, and a borrowed ulster over it. Such feats are pleasant to think of a few 
days afterward, when the weather has clianged its mind again, and the mereury is once more reaching for the century mark.

In the course of my five days I walked twice over the road newly cut through the mountain forest from the foot of Echo Lake to the golf grounds : first upward, in an afternoon, returning to Franconia by the old highway; then downward, in a forenoon, after reaching the lake by way of the Butter Hill road and the sleepers, that is to say, the railroad. Forenoon and afternoon the impression was the same, - silence, as if the birds' year were over, though everything was still green and the season not so late but that tardy wood-sorrel blossoms still showed, here and there one, among the clover-like leaves; old favorites, that I had not seen for perhaps a dozen years.

On the railroad - a place which I have always found literally alive with song and wings, not only in May and June, but in September and October - I walked for forty-five minutes, by the watch, without hearing so much as a bird's note. Almost the 
only living creature that I saw (three berrypickers and a dog excepted) was a red squirrel which sat on end at the top of a tall stump, with his tail over his back, and ate a raspberry, as if to show me how. "You think you are an epicure," he said; "and you stuff yourself so full in half an hour that you have to fast for half a day afterward. What sort of epicurean philosophy is that? Look at me." And I looked. He held the berry - which must have been something less than ripe - between his fore paws, just as he would have held a nut, and after looking at me to make sure I was paying attention twirled it round and round against his teeth till it grew smaller and smaller before my eyes, and then was gone. "There!" said the saucy chap, as he held up his empty fingers. The operation had consumed a full minute, at the very least. At that rate, no doubt, a man could swallow raspberries from morning till night. But what good would it do him? He might as well be swallowing the wind. No human mouth could tell raspberry juice from warm water, in doses so infinitesimal. 
The sight, nevertheless, gave me a new conception of the pitch of delicacy to which the sense of taste might be cultivated. It was evident that our human faculty, comfortably as we get on with it in the main, is only a coarse and bungling tool, never more than half made, perhaps, or quite as likely blunted and spoiled by'millenniums of abuse. I could really have envied the chickaree, if such a feeling had not seemed unworthy of a man's dignity. Besides, a palate so supersusceptible might prove an awkward possession, it occurred to me on second thought, for one who must live as one of the "civilized," and take his chances with cooks. All things considered, I was better off, perhaps, with the old equipment and the old method, - a duller taste and larger mouthfuls.

At the end of the forty-five minutes I came to the burning, a tract of forest over which a fire had run some two years before. Here, in this dead place, there was more of life; more sunshine, and therefore more insects, and therefore more birds. Even here, however, there was nothing to be called birdiness: a few olive-sided flycatchers and wood 
pewees, both with musical whistles, one like a challenge, the other an elegy; a family group of chestnut-sided warblers, parents and young, conversing softly among themselves about the events of the day, mostly gastronomic; a robin and a white-throated sparrow in song; three or four chickadees, lisping and deeing; a siskin or two, a song sparrow, and a red-eyed vireo. The whole tract was purple with willow herb - which follows fire as surely as boys follow a fire engine - and white with pearly immortelles.

Once out of this open space - this forest cemetery, one might say, though the dead were not buried, but stood upright like bleached skeletons, with arms outstretched - I was again immersed in leafy silence, which lasted till I approached the lake. Here I heard before me the tweeting of sandpipers, and presently came in sight of two solitaries (migrants already, though it was only the 4th of August), each bobbing nervously upon its boulder a little off shore. The eye of the ornithologist took them in: dark green legs; dark, slender bills; bobbing, not teetering - Totanus, not Actitis. 
Then the eyes of the man turned to rest upon that enchanting prospect: Eagle Cliff in shadow, Profile Mountain in full sun, and the lake between them. The spirit of all the hours I had ever spent here was communing with me. I blessed the place and bade it good-by. " I will come again if I can," I said, " and many times ; but if not, good-by." I believe I am like the birds; no matter how far south they may wander, when the winter is gone they say one to another, "Let us go back to the north country, to the place where we were so happy a year ago."

The last day of my visit, the only warm one, fell on Sunday; and on Sunday, by all our Franconia traditions, I must make the round of Landaff Valley. I had been into the valley once, to be sure, but that did not matter; it was not on Sunday, and besides, I did not really go "round the square," as we are accustomed to say, with a fine disregard of mathematical precision.

After all, there is little to tell of, though there was plenty to see and enjoy. The first thing was to get out of the village; away from the churches and the academy, and be- 
yond the last house (the last village house, I mean), into the company of the river, the long green meadow and the larch swamp, a goodly fellowship. A swamp sparrow trilled me a welcome at the very entrance to the valley, as he had done before, and musical goldfinches accompanied me for the whole round, till I thought the day should be named in their honor, Goldfinch Sunday.

Pretty Atlantis butterflies were always in sight, as they had been even in the coolest weather, with now and then an Atalanta and, more rarely, a Cybele. I had looked for Aphrodite, also, being desirous to see these three fritillaries (Cybele, Aphrodite, and Atlantis) together, till the entomologist told me that we were out of its latitude. Commoner even than Atlantis, perhaps, was the dusky wood-nymph, Alope (strange notions the old Greeks must have had of the volatility of their goddesses and heroines, to name so many of them after butterflies!), she of the big yellow blotch on each fore wing; a wavering, timid creature, always seeking to hide herself, and never holding a steady course for so much as an inch - as if 
she were afflicted with the shaking palsy. "Don't look at me! Pray don't look at me !" she is forever saying as she dodges behind a leaf. Shyness is a grace - in the feminine; but Alope is too shy. If her complexion were fairer, possibly she would be less retiring.

From the first the warmth of the sun was sufficient to render shady halts a luxury, and on the crossroad — "Gray Birch Road," to quote my own name for it - where a walker was somewhat shut away from the wind, I began to spell "warm" with fewer letters. Here, too, the dust was excessively deep, so that passing carriages - few, but too many - put a foot-passenger under a cloud. Still I was glad to be there, turning the old corners, seeing the old beauty, thinking the old thoughts. How green Tucker Brook meadow looked, and how grandly Lafayette loomed into the sky just beyond!

Most peculiar is the feeling I have for that sharp crest; I know not how to express it ; a feeling of something like spiritual possession. If I do not love it, at least I love the sight of it. Nay, I will say what I 
mean: I love the mountain itself. I take pleasure in its stones, and favor the dust thereof. The loftiest snow-covered peak in the world would never carry my thoughts higher, or detain them longer. It was good to see it once more from this point of special vantage. And when I reached the corner of the Notch road and started homeward, how refreshing was the breeze that met me! Coolness after heat, ease after pain, these are near the acme of physical comfort.

Best of all was a half-hour's rest under a pine tree, facing a stretch of green meadow, with low hills beyond it westward; a perfect picture, perfectly "composed." In the foreground, just across the way, stood a thicket of chokecherry shrubs shining with fruit, and over them, on one side, trailed a clematis vine full of creamy white blossoms. Both cherry and clematis were common everywhere, often in each other's company, but I had seen none quite so gracefully disposed. No gardener's art could have managed the combination so well.

Here I sat and dreamed. I was near home, with time to spare; the wind was per- 
fection, and the day also; I had walked far enough to make a seat welcome, yet not so far as to bring on sluggish fatigue; and everything in sight was pure beauty. Life will be sweet as long as it has such halfhours to offer us. Yet somehow, human nature having a perverse trick of letting good suggest its opposite, I found myself, all at once,

"In that sweet mood when pleasant thoughts Bring sad thoughts to the mind."

I looked at the garden patch and the mowed field, and thought what a strange world it is - ill-made, half-made, or unmade - in which man has to live, or, in our pregnant every-day phrase, to get his living; a world that goes whirling on its axis and revolving round its heat-and-light-giving body, - like a top which a boy has set spinning, - now roasted and parched, now drenched and sodden, now frozen dead; a world wherein, as our good American stoic complained, a man must burn a candle half the time in order to see to live; a world to which its imhabitants are so poorly adapted that a day of comfortable temperature is matter 
for surprise and thankfulness; a world which cannot turn round but that men die of heat and by freezing, of thirst and by drowning; a world where all things, appetite and passion, as well as heat and cold, run continually to murderous extremes. A strange world, surely, which men have agreed to justify and condemn in the same breath as the work of supreme wisdom, ruined by original sin. Children will have an explanation. The philosopher says : "My son, we must know how to be ignorant."

So my thoughts ran away with me till the clematis vine and the cherry bushes brought me back to myself. The present hour was good; the birds and the plants were happy; and so was I, though for the moment I had almost forgotten it. The mountain had its old inscrutable, beckoning, admonishing, benignant look. The wise make no complaint. If the world is not the best we could imagine, it is the best we have; and such as it is, it is a pretty comfortable place in vacation time and fair weather. Let me not be among the fools who waste a bright to-day in forecasting dull to-morrows. 


\section{RED LEAF DAYS}

"Woods over woods in gay theatric pride."

GoLDSMITH.

White Mountain woods are generally at their brightest in the last few days of September. This year I had but a week or so to stay among them, and timed my visit accordingly, arriving on the $22 \mathrm{~d}$. As I drove over the hills from Littleton to Franconia there were only scattered bits of high color in sight - a single tree here and there, which for some reason had hung out its autumnal flag in advance of its fellows. It seemed almost impossible that all the world would be aglow within a week; but I had no real misgivings. Seed time and harvest would not fail. The leaves would ripen in their time. And so the event proved. Day by day the change went visibly forward (visibly yet invisibly, as the hands go round 
the face of a clock), till by the 30 th the colors were as brilliant as one could wish, though with less than the usual proportion of yellow.

The white birches, which should have supplied that hue, were practically leafless. A small caterpillar (the larva of a tiny moth, one of the Microlepidoptera) had eaten the greenness from every white-birch leaf in the whole country roundabout. One side of Mount Cleveland, for example, looked from a distance as if a fire had swept over it. It was a real devastation; yet, to my surprise, as the maple groves turned red the total effect was little, if at all, less beautiful than in ordinary seasons. The leafless purplish patches gave a certain indefinable openness to the woods, and the eye felt the duller spaces as almost a relief. I could never have believed that destruction so widespread and lamentable could work so little damage to the appearance of the landscape. As the old Hebrew said, everything is beautiful in its time.

We were four at table, and in front of the evening fireplace, but in footing it we 
were only two. Sometimes we walked side by side; sometimes we were rods apart. When we felt like it we talked; then we went on a piece in silence, as Christians should. Let me never have a traveling companion who cannot now and then keep himself company. The ideal man for such a rôle is one who is wiser than yourself, yet not too wise, lest there be lack of reciprocity, and you find yourself no better than a boy rusticating with a tutor. He should be even-tempered, also, well furnished with philosophy, loving fair weather and good living, but taking things as they come ; and withal, while not unwilling to intimate his own preference as to the day's route and other matters, he should be always ready to defer with all cheerfulness to his partner's wish. "The ideal man," I say; but I am thinking of a real one.

We have become well known in the valley, after many years; so that, although we are almost the only walkers there, our ambulatory eccentricity has mostly ceased to provoke comment. At all events, the people no longer look upon us as men broken out 
of Bedlam. Time, we may say, has established our innocence. If a recent comer expresses concern as we go past, some older resident reassures him. "They are harmless," he says. "There used to be three of them. They pull weeds, as you see; the older one has his hands full of them now. Yes, they are branches of thorn bushes. They always carry opera glasses, too. We used to think they were looking for land to buy. Old —, up on the hill in Lisbon, tried to sell them his farm at a fancy figure, but they did n't bite. I reckon they know a thing or two, for all their queer ways. One of 'em knows how to write, anyhow; he is always taking out pencil and paper. There! you see how he does. He sets down a word or two, and away he goes again."

It is all true. We looked at plants, and sometimes gathered them. The botanist had thorn bushes on his mind, the genus Cratcegus being a hard one, and, as I judged, newly under revision. I professed no knowledge upon so recondite a subject, but was proud to serve the cause of science by pointing out a bush here and there. One 
hot afternoon, too, after a pretty long forenoon jaunt, I nearly walked my legs off, as the strong old saying is, following my leader far up the Landaff Valley ("down Easton way") to visit a bush of which some one had brought him word. It was an excellent specimen, the best we had yet seen; but it was nothing new, and by no means so handsome or so interesting as one found afterward by accident on our way to Bethlehem. That was indeed a beauty, and its abundant fruit a miracle of color.

Once I detected an aster which the botanist had passed by and yet, upon a second look, thought worth taking home; it was probably Lindleyanus, he said, and the event proved it; and at another time my eye caught by the wayside a bunch of chokecherry shrubs hung with yellow clusters. We were in a carriage at the time, four old Franconians, and not one of us had ever seen such a thing here before. Three of us had never seen such a thing anywhere; for my own part, I was in a state of something like excitement; but the Cratcegus collector, who knows American trees if any- 
body does, said: "Yes, the yellow variety is growing in the Arnold Arboretum, and is mentioned in the latest edition of Gray's Manual." Bushes have been found at Dedham, Massachusetts, it appears. The maker of the Manual seems not to have been aware of their having been noticed anywhere else; but since my return home I have been informed that they are not uncommon in the neighborhood of Montreal, where yellow chokecherries are "found with the ordinary form in the markets" !

That last statement is bewildering. Is there anything that somebody, somewhere, does not find edible? I have heard of eaters of arsenic and of slate pencils; but chokecherries for sale in a market! If the reader's mouth does not pucker at the words he must be wanting in imagination.

In Franconia even the birds seemed to refuse such a tongue-tying diet. The shrubs loaded with fruit, some of it red (wine color), some of it black, - the latter color predominating, I think, — stood along the roadside mile upon mile. Sooner or later, I dare say, the birds must have recourse to 
them; how else do the bushes get planted so universally? But at the time of our visit there was a sufficiency of better fare. Rum cherries were still plentiful, and birds, like boys in an apple orchard, and like sensible people anywhere, take the best first.

It surprised me, while I was here some years ago, to discover how fond woodpeckers of all kinds are of rum cherries. Even the pileated could not keep away from the trees, but came close about the house to frequent them. One unfortunate fellow, I regret to say, came once too often. The sapsuckers, it was noticed, went about the business after a method of their own. Each cherry was carried to the trunk of a tree or to a telegraph pole, where it was wedged into a crevice, and eaten with all the regular woodpeckerish attitudes and motions. Doubtless it tasted better so. And the bird might well enough have said that he was behaving no differently from human beings, who for the most part do not swallow fruit under the branches, but take it indoors and feast upon it at leisure, and with something like ceremony. The trunk of a tree is a woodpecker's table. 
And for all that, Franconia woodpeckers are not so conservative as not to be able to take up with substantial improvements. They know a good thing when they see it. These same sapsuckers, or one of them, was not slow to discover that one of our crew, an entomological collector, had set up here and there pieces of board besmeared with a mixture of rum and sugar. And having made the discovery, he was not backward about improving it. He went the round of the boards with as much regularity as the moth collector himself, and with even greater frequency. And no wonder. Here was a feast indeed; victuals and drink together; insects preserved in rum. Happy bird! As the most famous of sentimental travelers said on a very different occasion, "How I envied him his feelings!" For there seems to be no doubt that sapsuckers love a liquid sweetness, and take means of their own to secure it.

On our present trip my walking mate and I stopped to examine a hemlock trunk, the bark of which a woodpecker of some kind, almost certainly a sapsucker, had riddled 
with holes till it looked like a nutmeg grater; and the most noticeable thing about it was that the punctures - past counting - were all on the south side of the tree, where the sap may be presumed to run earliest and most freely. Why this particular tree was chosen and the others left is a different question, to which I attempt no answer, though I have little doubt that the maker of the holes could have given one. To vary a half-true Bible text, "All the labor of a woodpecker is for his mouth;" and labor so prolonged as that which had been expended upon this hemlock was very unlikely to have been laid out without a reason. Every judge of rum cherries knows that some trees bear incomparably better fruit than others growing close beside them; and why should a woodpecker, a specialist of specialists, be less intelligent touching hemlock trees and the varying quality of their juices? A creature who is beholden to nobody from the time he is three weeks old is not to be looked down upon by beings who live, half of them, in danger of starvation or the poorhouse. 
The end of summer is the top of the year with the birds. Their numbers are then at the full. After that, for six months and more, the tide ebbs. Winter and the long migratory journeys waste them like the plagues of Egypt. Not more than half of all that start southward ever live to come back again.

Of this every bird-lover takes sorrowful account. It is part of his autumnal feeling. If he sees a flock of bobolinks or of redwinged blackbirds, he thinks of the Southern rice fields, where myriads of both species — "rice-birds," one as much as the otherwill be shot without mercy. A sky full of swallows calls up a picture of thousands lying dead at once, in Florida or elsewhere, after a winter storm. A September humming-bird leaves him wondering over its approaching flight to Central America or to Cuba. Will the tiny thing ever accomplish that amazing passage and find its way home again to New England? Perhaps it will; but more likely not.

For the present, nevertheless, the birds are all in high spirits, warbling, twittering, 
feeding, chasing each other playfully about, as if life were nothing but holiday. Little they know of the future. And almost as little know we. Blessed ignorance! It gives us all, birds and men alike, many a good hour. If my playmate of long ago had foreseen that he was to die at twenty, he would never have been the happy boy that I remember. Those few bright years he had, though he had no more. So much was saved from the wreck.

Thoughts of this kind come to me as I recall an exhilarating half hour of our recent stay in Franconia. It was on the first morning, immediately after breakfast. We were barely out of the hotel yard before we turned into a bit of larch and alder swamp by the shore of Gale River. We could do nothing else. The air was full of chirps and twitters, while the swaying, feathery tops of the larches were alive with flocks of whispering waxwings, the greater part of them birds of the present year, still wearing the stripes which in the case of so many species are marks of juvenility. If individual animals still pass through a development answering 
to that which the race as a whole has undergone - if young animals, in other words, resemble their remote ancestors - then the evolution of birds' plumage must have gone pretty steadily in the direction of plainness. Robins, we must believe, once had spotted breasts, as most of their more immediate relatives have to this day, and chipping sparrows and white-throats were streaked like our present song sparrows and baywings. If the world lasts long enough (who knows ?) all birds may become monochromatic. Wingbars and all such convenient marks of distinction will have vanished. Then, surely, amateurish ornithologists will have their hands full to name all the birds without a gun. Then if, by any miraculous chance, a copy of some nineteenth century manual of ornithology shall be discovered, and some great linguist shall succeed in translating it, what a book of riddles it will prove! Savants will form theories without number concerning it, settling down, perhaps, after a thousand years of controversy, upon the belief that the author of the ancient work was a man afflicted with color blindness. If not, 
how came he to describe the scarlet tanager as having black wings and tail, and the brown thrasher a streaked breast?

These are afterthoughts. At the moment we were busy, eyes and ears, taking a census of the swamp. Besides the waxwings, which were much the most numerous, as well as the most in sight — "tree-toppers," one of my word-making friends calls them - there were robins, song sparrows, white-throats, field sparrows, goldfinches, myrtle warblers, a Maryland yellow-throat, a black-throated green, a Nashville warbler, a Philadelphia vireo, two or three solitary vireos, one or more catbirds, as many olive-backed thrushes, a white-breasted nuthatch, and a sapsucker. Others, in all likelihood, escaped us.

In and out among the bushes we made our way, one calling to the other softly at each new development.

"What was that?" said I. "Was n't that a bobolink?"

"It sounded like it," answered the other listener.

"But it can't be. Hark!"

The quick, musical drop of sound-a 
"stillicidious" note, my friend called it was heard again. No ; it was not from the sky, as we had thought at first, but from a thicket of alders just behind us. Then we recognized it, and laughed at ourselves. It was the staccato whistle of an olive-backed thrush, a sweet familiarity, over which I should have supposed it impossible for either of us to be puzzled.

The star of the flock, as some readers will not need to be told, having marked the unexpected name in the foregoing list, was the Philadelphia vireo. What a bright minute it is in a man's vacation when such a stranger suddenly hops upon a branch before his eyes! He feels almost like quoting Keats. "Then felt I," he might say, not with full seriousness, perhaps, -

"Then felt I like some watcher of the skies

When a new planet swims into his ken."

Yet how unconcerned the bird seems! To him it is all one. He knows nothing of his spectator's emotions. Rarity? What is that? He has been among birds of his own kind ever since he came out of the egg. Sedately he moves from twig to twig, think- 
ing only of another insect. This minute is to him no better than any other. And the man's nerves are tingling with excitement.

"You will hardly believe me," said my companion, who had hastened forward to look at the stranger, "but this is the second one I have ever seen."

But why should I not believe him? It was only my third one. Philadelphia vireos do not feed in every bush. Be it added, however, that I saw another before the week was out.

There were many more birds here now than I had found six or seven weeks before; but there was much less music. In early August hermit thrushes sang in sundry places and at all hours; now a faint chuck was the most that we heard from them, and that but once. And still our September vacation was far from being a silent one. Song sparrows, vesper sparrows, whitethroats, goldfinches, robins, solitary vireos, chickadees (whose whistle is among the sweetest of wild music, I being judge), phobes, and a catbird, all these sang more or less frequently, and more or less well, 
though all except the goldfinches and the chickadees were noticeably out of voice. Once a grouse drummed, and once a flicker called $h i, h i$, just as in springtime; and every warm day set the hylas peeping. Once, too, a ruby-crowned kinglet sang for us with all freedom, and once a gold-crest. The latter's song is a very indifferent performance, hardly to be called musical in any proper sense of the word; nothing but his ordinary zee-zee-zee, with a hurried, jumbled, ineffective coda; yet it suggests, and indeed is much like, a certain few notes of the rubycrown's universally admired tune. The two songs are evidently of a common origin, though the ruby-crown's is so immeasurably superior that one of my friends seemed almost offended with me, not long ago, when I asked him to notice the resemblance between the two. None the less, the resemblance is real. The homeliest man may bear a family likeness to his handsome brother, though it may show itself only at times, and chance acquaintances may easily be unaware of its existence.

The breeziest voice of the week was a 
pileated woodpecker's - a flicker's resonant $h i, h i$, in a fuller and clearer tone; and one of the most welcome voices was that of an olive-backed thrush. We were strolling past a roadside tangle of shrubbery when some unseen bird close by us began to warble confusedly (I was going to say autumnally, this kind of formless improvisation being so characteristic of the autumnal season), in a barely audible voice. My first thought was of a song sparrow; but that could hardly be, and I looked at my companion to see what he would suggest. He was in doubt also. Then, all at once, in the midst of the vocal jumble, our ears caught a familiar strain. "Yes, yes," said I, " a Swainson thrush," and I fell to whistling the tune softly for the benefit of the performer, whom I fancied, rightly or wrongly, to be a youngster at his practice. Young or old, the echo seemed not to put him out, and we stood still again to enjoy the lesson; disconnected, unrelated notes, and then, of a sudden, the regular Swainson measure. I had not heard it before since the May migration.

Every bird season has peculiarities of its 
194 FOOTING IT IN FRANCONIA

own, in Franconia as elsewhere. This fall, for example, there were no crossbills, even at Lonesome Lake, where we have commonly found both species. White-crowned sparrows were rare; perhaps we were a little too early for the main flight. We saw one bird on September 23, and two on the 26th. Another noticeable thing was a surprising scarcity of red-bellied nuthatches. We spoke often of the great contrast in this respect between the present season and that of three years ago. Then all the woods, both here and at Moosilauke, fairly swarmed with these birds, till it seemed as if all the Canadian nuthatches of North America were holding a White Mountain congress. The air was full of their nasal calls. Now we could travel all day without hearing so much as a syllable. The tide, for some reason, had set in another direction, and Franconia was so much the poorer. 


\section{AMERICAN SKYLARKS}

"Right hard it was for wight which did it heare, To read what manner musicke that mote bee."

SPENSER.

ON the second day after our arrival in Franconia ${ }^{1}$ we were following a dry, sandy stretch of valley road - on one of our favorite rounds - when a bird flew across it, just before us, and dropped into the barren, closely cropped cattle pasture on our left. Something indefinable in its manner or appearance excited my suspicions, and I stole up to the fence and looked over. The bird was a horned lark, the first one that I had ever set eyes on in the nesting season. He seemed to be very hungry, snapping up insects with the greatest avidity, and was not in the least disturbed by our somewhat eager attentions. It was plain at the first glance

1 This and the two succeeding chapters are records of a vacation visit in May, 1901 . 
that he was of the Western variety, - a prairie horned lark, in other words, _- for even in the best of lights the throat and sides of the head were white, or whitish, with no perceptible tinge of yellow.

The prairie lark is one of the birds that appear to be shifting or extending their breeding range. It was first described as a sub-species in 1884, and has since been found to be a summer resident of northern Vermont and New Hampshire, and, in smaller numbers, of western Massachusetts. It is not impossible, expansion being the order of the day, that some of us may live long enough to see it take up its abode within sight of the gilded State House dome.

My own previous acquaintance with it had been confined to the sight of a few migrants along the seashore in the autumn, although my companion on the present trip had seen it once about a certain upland farm here in Franconia. "That was ten years ago, and we have again: and again sought it there since, without avail.

Our bird of to-day interested me by displaying his "horns," — curious adornments 
which I had never been able to make out before, except in pictures. They were not carried erect, — like an owl's "ears," let us say, _ but projected backwards, and with the head at a certain angle showed with perfect distinctness. The bird would do nothing but eat, and as our own dinner awaited us we continued our tramp. We would try to see more of him and his mate at another time, we promised ourselves.

First, however, we paid a visit (that very afternoon) to the upland farm just now spoken of. "Mears's," we always call it. Perhaps the larks would be there also. But we found no sign of them, and the bachelor occupant of the house, who left his plough in the beanfield to offer greeting to a pair of strangers, assured us that nothing answering to our description had ever been seen there within his time; an assertion that might mean little or much, of course, though he seemed to be a man who had his eyes open.

This happened on May 17. Six days afterward, in company with an entomological collector, we were again in the dusty valley. I went into the larch swamp in search of a 
Cape May warbler - found here two years before - one of the very best of our Franconia birds; and the entomologist stayed near by with her net and bottles, while the second man kept on a mile farther up the valley to look for thorn-bush specimens. So we drove the sciences abreast, as it were. My own hunt was immediately rewarded, and when the botanist returned I thought to stir his envy by announcing my good fortune; but he answered with a smile that he too had seen something; he had seen the prairie lark soaring and singing. "Well done!" said I; "now you may look for the Cape May, and incidentally feed the mosquitoes, and the lady and I will get into the carriage and take our turn with Otocoris." So said, so done. We drove to the spot, the driver stopped the horses opposite a strip of ploughed land, and behold, there was the bird at that very moment high in the air, hovering and singing. It was not much of a song, I thought, though the entomologist, hearing partly with the eye, no doubt, pronounced it beautiful. It was most interesting, whatever might be said of its musical 
quality, and as we drove homeward my companion and I agreed that we would take up our quarters for a day or two at the nearest house, and study it more at our leisure. Possibly we should happen upon a nest.

In the forenoon of May 25, therefore, we found ourselves comfortably settled in the very midst of a lark colony. The birds, of which there were at least five (besides two pairs found half a mile farther up the valley), were to be seen or heard at almost any minute; now in the road before the house, now in the ploughed land close by it, now in one of the cattle pastures, and now on the roofs of the buildings. One fellow spent a great part of his time upon the ridgepole of the barn (a pretty high structure), commonly standing not on the very angle or ridge, but an inch or two below it, so that very often only his head and shoulders would be visible. Once I saw one dusting himself in the rut of the road. He went about the work with great thoroughness and unmistakable enjoyment, cocking his head and rubbing first one cheek and then the other into the sand. "Cleanliness is next to godliness," I thought I heard him saying. 
So far as we could judge from our two days' observation, the birds were most musical in the latter half of the afternoon, say from four o'clock to six. Contrary to what we should have expected, we saw absolutely no ascensions in the early morning or after sunset, although we did see more than one at high noon. It is most likely, I think, that the birds sing at all hours, as the spirit moves them, just as the nightingale does, and the hermit thrush and the vesper sparrow.

As for the quality and manner of the song, with all my listening and studying I could never hit upon a word with which to characterize it. The tone is dry, guttural, inexpressive ; not exactly to be called harsh, perhaps, but certainly not in any true sense of the word musical. When we first heard it, in the distance (let the qualification be noted), the same thought came to both of us, - a kingbird's formless, hurrying twitters. There is no rhythm, no melody, nothing to be called phrasing or modulation, a mere jumble of "splutterings and chipperings." Every note is by itself, having to my 
ear no relation to anything before or after. The most striking and distinguishing characteristic of it all is the manner in which it commonly hurries to a conclusion - as if the clock were running down. "The hand has slipped from the lever," I more than once found myself saying. I was thinking of a motorman who tightens his brake, and tightens it again, and then all at once lets go his grip. At this point, this sudden acceleration and conclusion, my companion and I always laughed. The humor of it was irresistible. It stood in such ludicrous contrast with all that had gone before, — so halting and labored; like a man who stammers and stutters, and then, finding his tongue unexpectedly loosened, makes all speed to finish. Sometimes - most frequently, perhaps - the strain was very brief; but at other times a bird would sit on a stone, or a fence-post, or a ridgepole, and chatter almost continuously by the quarter-hour. Even then, however, this comical hurried phrase would come in at more or less regular intervals. I imagined that the larks looked upon it as the highest reach of their art and delivered it 
with special satisfaction. If they did, I could not blame them; to us it was by all odds the most interesting part of their very limited repertory.

The most interesting part, I mean, of that which appealed to the ear; for, as will readily be imagined, the ear's part was really much the smaller half of the performance. The wonder of it all was not the music by itself (that was hardly better than an oddity, a thing of which one might soon have enough), but the music combined with the manner of its delivery, while the singer was climbing heavenward. For the bird is a true skylark. Like his more famous cousin, he does not disdain the humblest perch - a mere clod of earth answers his purpose; but his glory is to sing at heaven's gate.

His method at such times was a surprise to me. He starts from the ground silently, with no appearance of lyrical excitement, and his flight at first is low, precisely as if he were going only to the next field. Soon, however, he begins to mount, beating the air with quick strokes and then shutting his wings against his sides and forcing himself upward. 
"Diving upward," was the word I found myself using. Up he goes, - up, up, up, " higher still, and higher," - till after a while he breaks into voice. While singing he holds his wings motionless, stiffly outstretched, and his tail widely spread, as if he were doing his utmost to transform himself into a parachute - as no doubt he is. Then, the brief, hurried strain delivered, he beats the air again and makes another shoot heavenward. The whole display consists of an alternation of rests accompanied by song (you can always see the music, though it is often inaudible), and renewed upward pushes.

In the course of his flight the bird covers a considerable field, since as a matter of course he cannot ascend vertically. He rises, perhaps, directly at your feet, but before he comes down, which may be in one minute or in ten, he will have gone completely round you in a broad circle; so that, to follow him continuously (sometimes no easy matter, his altitude being so great and the light so dazzling), you will be compelled almost to put your neck out of joint. In our own ease, we generally did not see him start, but were 
made aware of what was going on by hearing the notes overhead.

One grand flight I did see from beginning to end, and it was wonderful, amazing, astounding. So I thought, at all events. There was no telling, of course, what altitude the bird reached, but it might have been miles, so far as the effect upon the beholder's emotions was concerned. It seemed as if the fellow never would be done. "Higher still, and higher." Again and again this line of Shelley came to my lips, as, after every bar of music, the bird pushed nearer and nearer to the sky. At last he came down; and this, my friend and I always agreed, was the most exciting moment of all. He closed his wings and literally shot to the ground head first, like an arrow. "Wonderful!" said I, "wonderful!" And the other man said: "If I could do that I would never do anything else."

Here my story might properly enough end. The nest of which we had talked was not discovered. My own beating over of the fields came to nothing, and my companion, as if unwilling to deprive me of a possible 
honor, contented himself with telling me that I was looking in the wrong place. Perhaps I was. It is easy to criticise. For a minute, indeed, one of the farm-hands excited our hopes. He had found a nest which might be the lark's, he thought; it was on the ground, at any rate; but his description of the eggs put an end to any such possibility, and when he led us to the nest it turned out to be occupied by a hermit thrush. Near it he showed us a grouse sitting upon her eggs under a roadside fence. It was while repairing the fence that he had made his discoveries. He had an eye for birds. "Those little humming-birds," he remarked, "they 're quite an animal." And. he was an observer of human nature as well. "That fellow," he said, speaking of a young man who was perhaps rather good-natured than enterprising, "that fellow don't do enough to break the Sabbath.",

And this suggests a bit of confession. We were sitting upon the piazza, on Sunday afternoon, when a lark sang pretty far off. "Well," said the botanist, " he sings as well as a savanna sparrow, anyhow." "A sa- 
vanna sparrow!" said I; and at the word we looked at each other. The same thought had come to both of us. Several days before, in another part of the township, we had heard in the distance - in a field inhabited by savanna and vesper sparrows - an utterly strange set of bird-notes. "What is that?" we both asked. The strain was repeated. "Oh, well," said I, " that must be the work of a crazy savanna. Birds are given to such freaks, you know." The grass was wet, we had a long forenoon's jaunt before us, and although my companion, as he said, "took no stock" in my explanation, we passed on. Now it flashed upon us both that what we had heard was the song of a prairie lark. "I believe it was," said the botanist. "I know it was," said I; "I would wager anything upon it." And it was; for after returning to the hotel our first concern was to go to the place - only half a mile away - and find the bird. And not only so, but twenty-four hours later we saw one soaring in his most ecstatic manner over another field, a mile or so beyond, beside the same road. 
The present was a good season for horned larks in Franconia, we told ourselves. Two years ago, at this same time of the year, I had gone more than once past all these places. If the birds were here then I overlooked them. The thing is not impossible, of course ; there is no limit to human dullness; but I prefer to think otherwise. A man, even an amateur ornithologist, should believe himself innocent until he is proved guilty. 


\section{A QUIET MORNING}

"Such was the bright world on the first seventh day."

Henry Vaughan.

IT is Sunday, May 26, the brightest, pleasantest, most comfortable of forenoons. I am seated in the sun at the base of an ancient stone wall, near the road that runs along the hillside above the Landaff Valley. Behind me is a little farmhouse, long since gone to ruin. At my feet, rather steeply inclined, is an old cattle pasture thickly strewn with massive boulders. The prospect is one of those that I love best. In the foreground, directly below, is the valley, freshly green, and, as it looks from this height, as level as a floor. Alder rows mark the winding course of the river, and on the farther side, close against the forest, runs a road, though the eye, of itself, would hardly know it.

Across the valley are the glorious newly 
clad woods, more beautiful than words can begin to tell; and beyond them rise the mountains: Moosilauke, far enough away to be blue; the shapely Kinsman range, at whose long green slopes no man need tire of looking; rocky Lafayette, directly in front of me; Haystack, with its leaning knob; the sombre Twins and the more Alpinelooking Washington, Jefferson, and Adams. Farther to the north are the low hills of Cleveland and Agassiz. A magnificent horizon. Lafayette, Washington, Jefferson, and Adams are still flecked with snow. And over the mountains is the sky, with high white clouds, cirrus and cumulus. I look first at the mountains, then at the valley, which is filled with sunlight as a cup is filled with wine. The level foreground is the essential thing. Without it the grandest of mountain prospects is never quite complete.

Swallows circle about me continually, a phœbe calls at short intervals, and less often I hear the sweet voice of a bluebird. Both phobe and bluebird are most delightfully plentiful in all this fair mountain country. 
They are of my own mind: they like old farms within sight of hills. Crows caw, a jay screams, and now and then the hurrying drumbeats of a grouse come to my ears. Somewhere in the big sugar grove behind me a great-crested flycatcher has been shouting almost ever since I sat down. The "great screaming flycatcher," he should be called. His voice is more to the point than his crest. He loves the sound of it.

How radiantly beautiful the red maple groves are just now! I can see two, one near, the other far off, both in varying shades of red, yellow, and green. The earth wears them as ornaments, and is as proud of them, I dare believe, as of the Parthenon. They are bright, but not too bright. They speak of youth - and the eye hears them. A red-eye preaches as if he knew the day of the week. What a gift of reiteration! "Buy the truth," he says. " Going, going!" But it is never gone. Down the valley road goes an open carriage. In it are a man and a woman, the woman with a parasol over her head. A song sparrow sings his little tune, and the bluebird gives himself up to war- 
bling. Few voices can surpass his for sweetness and expressiveness. The grouse drums again (let every bird be happy in his own way), a myrtle warbler trills (a talker to himself), and a passing goldfinch drops a melodious measure. All the chokecherry bushes are now in white. The day may be Whitsunday for all that my unchurchly mind can say. Red cherries, which whitened the world a few days ago, are fast following the shadbushes, which have been out of flower for a week. Apple trees, too, have passed the height of their splendor. The vernal procession moves like a man in haste.

The sun grows warm. I will betake myself to the maple grove and sit in the shadow; but first I notice in the grass by the wall an abundance of tiny veronica flowers (speedwell) - white, streaked with purple, as I perceive when I pluck one. Not a line but runs true. Everything is beautiful in its time; the little speedwell no less than the valley and the mountain. A red squirrel, far out on a tilting elm spray, is eating his fill of the green fruit. Mother 
Earth takes care of her children. She raises elm seeds as man raises wheat. And foolish man wonders sometimes at what he thinks her waste of vital energy.

I have found a seat upon a prostrate maple trunk, one of the fathers of the grove, so huge of girth that it was almost a gymnastic feat to climb into my position. Here I can see the valley and the mountains only in parts, between the leafy intervening branches. Which way of seeing is the better I will not seek to determine. Both are good - both are better than either. A flycatcher near me is saying chebec with such emphasis that though I cannot see him I can imagine that he is almost snapping his head off at every utterance. Much farther away is a relative of his; we call him the olive-side. (I wonder what name the birds have for us.) Que-quee-o, he whistles in the clearest of tones. $\mathrm{He}$ is one of the good ones. And how well his voice "carries" - as if one grove were speaking to another!

About my feet are creamy white tiarella spires and pretty blue violets. The air is 
full of the hum of insects, but they are all innocent. I sit under my own beech and maple tree, with none to molest or make me afraid. How many times I have heard something like that on a Sunday forenoon! Year in and out, our dear old preacher could never get through his "long prayer" without it. He would not be sorry to know that I think of him now in this natural temple.

An unseen Nashville warbler suddenly announces himself. "If you must scribble," he says, "my name is as good as anybody's." The little flycatcher has not yet dislocated his neck. Chebec, chebec, he vociferates. The swallows no longer come about me. They care not for groves. They are for the open sky, the grass fields, and the sun; but I hear them twittering overhead. If I could be a bird, I think I would be a swallow. Hark! Yes, there is the syllabled whistle of a white-breasted nuthatch. He must go into my vacation bird-list-No. 79, Sitta carolinensis. If he would have shown himself sooner he should have had a higher place. And now, to my surprise, I hear the rollicking voice of a bobolink. The meadow 
below contains many of his happy kind, and one of them has come up within hearing to brighten my page.

All the time I have sat here I have been hoping to hear the hearty, "full-throated" note of a yellow-throated vireo. This is the only place in Franconia where I have ever heard it - two years ago this month. But the bird seems not to be here now, and I must not stay longer. My companion, who has gone higher up the hill to visit a thorn bush, will be expecting me on the bridge by the old grist-mill.

Before I can get away, however, I add another name to my bird-list, _ a welcome name, the wood pewee's. He has just arrived from the South, I suppose. What a sweetly modulated, plaintive-sounding whistle! How different from the bobolink's "jest and youthful jollity!" And now the crested breaks out again all at once, after a long silence. There is a still stronger contrast. Four flycatchers are in voice together: the crested, the olive-sided, the least, and the wood pewee. I have heard them all within the space of a minute. As soon as I 
am in the valley I shall hear the alder flycatcher, and when, braving the mosquitoes, I venture into the tamarack swamp a little way to look at the Cape May warbler (I know the very spot) I shall doubtless hear the yellow-belly. These, with the kingbird and the phobe, which are about all the farms, make the full New Hampshire contingent. No doubt there are flies enough for all of them.

As I start to leave the grove, stepping over beds of round-leaved violets and spring beauties, both out of flower already, I start at the sound of an unmusical note, which I do not immediately recognize, but which in another instant I settle upon as a sapsucker's. This is a bird at whose absence my companion and I have frequently expressed surprise, remembering how common we have found him in previous visits. I go in pursuit at once, and presently come upon him. $\mathrm{He}$ is in extremely bright plumage, his crown and his throat blood red. He goes down straightway as No. 81. I am having a prosperous day. Three new names within half an hour ! Idling in a sugar orchard 
is good for a man's bird-list as well as for his soul.

An oven-bird is declaiming, a blue yellow-back is practicing scales, and a field sparrow is chanting. And even as I pencil their names a nuthatch (the very one I have been hearing) flies to a maple trunk and alights for a moment at the door of his nest. Without question he passed a morsel to his brooding mate, though I was not quick enough to see him. Yes, within a minute or two he is there again; but the sitting bird does not appear at the entrance; her mate thrusts his bill into the door instead. The happy pair! There is much family life of the best sort in a wood like this. No doubt there are husbands and wives, so called, in Franconia as well as in other places, who might profitably heed the old injunction, "Behold the fowls of the air." 


\section{IN THE LANDAFF VALLEY}

THE greatest ornithological novelty of our present visit to Franconia was the prairie horned larks, whose lyrical raptures, falling "from heaven or near it," I have already done my best to describe. The rarest bird (for there is a difference between novelty and rarity) was a Cape May warbler ; the most surprisingly spectacular was a duck. Let me speak first of the warbler.

Two years ago I found a Cape May settled in a certain spot in an extensive tract of valley woods. The manner of the discovery - which was purely accidental, the bird's voice being so faint as to be inaudible beyond the distance of a few rods - and the pains I took to keep him under surveillance for the remainder of my stay, so as to make practically sure of his intention to pass the summer here, have been fully recounted in a previous chapter. The experience was one 
of those which fill an enthusiast with such delight as he can never hope to communicate, or even to make seem reasonable, except to men of his own kind.

We had never met with Dendroica tigrina before anywhere about the mountains, and I had no serious expectation of ever finding it here a second time. Still "hope springs immortal;" "the thing that hath been, it is that which shall be;" and one of my earliest concerns, on arriving in Franconia again at the right season of the year, was to revisit the well-remembered spot and listen for the equally well-remembered sibilant notes.

Our first call was on May 17. Perhaps we were ahead of time; at any rate, we found nothing. On the $23 \mathrm{~d}$ we passed the place again, and heard, somewhat too far away, what I believed with something like certainty to be the zee-zee-zee-zee of the bird we were seeking; but the dense underbrush was drenched with rain, we had other business in hand, and we left the question unsettled. If the voice really was the Cape May's we should doubtless have another chance with him. So I told my companion; and the re- 
sult justified the prophecy, which was based upon the bird's behavior of two years before, when all his activities seemed to be very narrowly confined - say within a radius of four or five rods.

We had hardly reached the place, two days afterward, before we heard him singing close by us, - in the very clump of firs where he had so many times shown himself, - and after a minute or two of patience we had him under our opera-glasses. The sight gave me, I am not ashamed to confess, a thrill of exquisite pleasure. It was something to think of - the return of so rare a bird to so precise a spot. With all the White Mountain region, not to say all of northern New England and of British America, before him, he had come back from the tropics (for who could doubt that he was indeed the bird of two years ago, or one of that bird's progeny?) to spend another summer in this particular bunch of Franconia evergreens. He had kept them in mind, wherever he had wandered, and, behold, here he was again, singing in their branches, as if he had known that I should be coming hither to find him. 
The next day our course took us again past his quarters, and he was still there, and still singing. I knew he would be. He could be depended on. He was doing exactly as he had done two years before. You had only to stand still in a certain place (I could almost find it in the dark, I think), and you would hear his voice. $\mathrm{He}$ was as sure to be there as the trees.

That afternoon some ladies wished to see him, and my companion volunteered his escort. Their experience was like our own; or rather it was better than ours. The warbler was not only at home, but behaved. like the most courteous of hosts; coming into a peculiarly favorable light, upon an uncommonly low perch, and showing himself off to his visitors' perfect satisfaction. It was bravely done. He knew what was due to "the sex."

On the morning of the 27th I took my farewell of him. He had been there for at least five days, and would doubtless stay for the season. May joy stay with him. I think I have not betrayed his whereabouts too nearly. If I have, and harm comes of it, 
may my curse follow the man that shoots him.

The "spectacular duck," of which I have spoken, was one of several (three or more) that seemed to be settled in the valley of the Landaff River. Our first sight of them was on the 20th; two birds, flying low and calling, but in so bewildering a light, and so quick in passing, that we ventured no guess as to their identity. Three days later, on the morning of the $23 \mathrm{~d}$, we had hardly turned into the valley before we heard the same low, short-breathed, grunting, grating, croaking sounds, and, glancing upward, saw three ducks steaming up the course of the river. This time, as before, the sun was against us, but my companion, luckier than I with his glass, saw distinctly that they carried a white speculum or wing-spot.

We were still discussing possibilities, supposing that the birds themselves were clean gone, when suddenly (we could never tell how it happened) we saw one of them - still on the wing - not far before us; and even as we were looking at it, wondering where it had come from, it flew toward the old grist- 
mill by the bridge and came to rest on the top of the chimney! Here was queerness. We leveled our glasses upon the creature and saw that it was plainly a merganser (shelldrake), with its crest feathers projecting backward from the crown, and its wing well marked with white. Its head, unless the light deceived me, was brown. The main thing, however, for the time being, was none of these details, but the spectacle of the bird itself, in so strange and sightly a position. "It looks like the storks of Europe," said my companion. Certainly it looked like something other than an every-day American duck, with its outstretched neck and its long, slender, rakish bill showing in silhouette against the sky.

Meanwhile, it had put its head partly out of sight in the top of the chimney, as if it had a nest there and were feeding its young. Then of a sudden it took wing, but in a minute or two was back again, to our increasing wonderment; and again it dropped the end of its bill out of sight below the level of the topmost bricks. Now, however, I could see the mandibles in motion, as if it 
were eating. Probably it had brought a fish up from the river. The chimney was simply its table. Again, for no reason that was apparent to us, it flew away, and again, after the briefest absence, it returned. A third time it vanished, and this time for good. We kept on our way up the valley, talking of what we had seen, but after every few rods I turned about to put my glass upon the chimney. Evidently that was the duck's favorite perch, I said; we should find it there often. But whether my reasoning was faulty or we were simply unfortunate, the fact is that we saw it there no more. On the 25th, at a place two miles or more above this point, we saw a duck of the same kind - at least it was uttering the same grating, croaking sounds as it flew; and a resident of the neighborhood, whom we questioned about the matter, told us that he had noticed such birds ("ducks with white on their wings") flying up and down the valley, and had no doubt that they summered there. As to their fondness for chimney-tops he knew nothing; nor do I know anything beyond the simple facts as I have here set them down. 
But I am glad of the picture of the bird that I have in my mind.

Enthusiasm is a good painter; it is not afraid of high lights, and it deals in fast colors. And to us old Franconians, enthusiasm seems to be one of the institutions, one of the native growths, one of the special delectabilities, if you please, of that delectable valley. The valley of cinnamon roses, we have before now called it; the valley of strawberries, blueberries, and raspberries; the valley of bobolinks and swallows; but best of all, perhaps, it is the valley of hobbyists. Its atmosphere is heady. We all feel it. The world is far away. Worldly successes, yea, dollars and cents themselves, are nothing, and less than nothing, and vanity. A new flower, a new bird, the hundred and fiftieth spider, these are the things that count. We are like members of a conventicle, or like the logs on the hearth. Our inward fires are mutually communicative and sustaining. We laugh now and then, it may be, at one another's peculiarities. Each of us can see, at certain moments, that the other is " a little off," to use a " Francony" 
phrase; not quite "all there," perhaps; a kind of eighth dreamer, "moving about in worlds not realized;" but at bottom we are sympathetic and appreciative. We would not have each other different, unless, indeed, it were a little younger. A grain of oddity is a good spice. If we are not deeply interested in the newest discovery, at least we participate in the exultation of the discoverer.

"That's a good fly," said the entomologist. We were driving, three of us, talking of something or nothing (we are never careful which it is), when the happy dipteran blundered into the carriage, and into the very lap of its admirer. Ten seconds more, and it was under the anæsthetic spell of cyanide of potassium, which (so we are told) puts its victims to sleep as painlessly, perhaps as blissfully, as chloroform. It was an inspiration to see how instantly the lady recognized a "good" one (it was one of a thousand, literally, for the day was summerlike), and how readily, and with no waste of motions, she made it her own. I was reminded of a story.

A friend of mine, a truly devout woman, 
of New England birth, and churchly withal (her books have all a savor of piety, though all the world reads them), is also an enthusiastic and widely famous entomological collector. One Sunday she had gone to church and was on her lnees reciting the service (or saying her prayers - I am not sure that I remember her language verbatim), when she noticed on the back of the pew immediately in front of her a diminutive moth of some rare and desirable species. Instinctively her hand sought her pocket, and somehow, without disturbing the congregation or eveu her nearest fellow-worshiper (my helpless masculine mind cannot imagine how the thing was done) she found it and took from it a "poison bottle," always in readiness for such emergencies. Still on her knees (whether her lips still moved is another point that escapes positive recollection), she removed the stopple, placed the mouth of the vial over the moth (which had probably imagined itself safe in such ecclesiastical surroundings), replaced the stopple above it, slipped the bottle back into her pocket, and resumed (or kept on with) her prayers. All this had 
taken but a minute. And who says that she had done anything wrong? Who hints at a disagreement between science and faith? Nay, let us rather believe with Coleridge -

"He prayeth best, who loveth best All things, both great and small," -

especially small church-going lepidoptera of the rarer sorts.

With zealots like this about you, as I have intimated, you may safely speak out. If you have seen an unexpected, long-expected warbler, or a chimney-top duck, or a skyward soaring lark, you may talk of it without fear, with no restraint upon your feelings or your phrases. Here things are seen as they are; truth is cleared of false lights, and Wisdom is justified of her children. Happy Franconia!

"Has she not shown us all?

From the clear space of ether, to the small Breath of new buds unfolding? From the meaning Of Jove's large eyebrow, to the tender greening Of April meadows?"

Happy Franconia! "Nested and quiet in a valley mild!" I think of her June strawberries and her perennial enthusiasms, and I wish I were there now. 


\section{A VISIT TO MOUNT AGASSIZ}

Mount Agassiz is rather a hill than a mountain; there is no glory to be won in climbing it, unless, perhaps, by very small children and elderly ladies; but if a man is in search of a soul-filling prospect he may climb higher and see less. The road to it, furthermore (I speak as a Franconian), is one of those that pay the walker as he goes along. Every rod of the five miles is worth traveling for its own sake, especially on a bright and comfortable August morning such as the Fates had this time sent me. It was eight o'clock when I set out, and with a sandwich in my pocket I meant to be in no haste. If invitations to linger by the way were as many and as pressing as I hoped for, a mile and a quarter to the hour would be excellent speed.

Red crossbills and pine siskins were calling in the larch trees near the house as 
I left the piazza. The siskins have never been a frequent sight with me in the summer season, and finding almost at once a flock in the grass by the roadside, feeding upon seeds, as well as I could make out, and delightfully fearless, I stopped for a few minutes to look them over. Some of the number showed much more yellow than others, but none of them could have been dressed more strictly in the fashion if their costumes had come straight from Paris. Every bird was in stripes.

Both they and the crossbills are what writers upon such themes agree to pronounce "erratic" and "irregular." Of most birds it can be foretold that they will be in certain places at certain times; their orbits are known; but crossbills and siskins wander through space as the whim takes them. If they have any scherlule of times and seasons, men have yet to discover it. When I come to Franconia, for example, I never can tell whether or not I shall find them; a piece of ignorance to be thankful for, like many another. The less knowledge, within limits, the more surprise; and the 
more surprise - also within limits - the more pleasure. At present I can hardly put my head out of the door without hearing the wheezy calls of siskins and the importunate cackles of crossbills. They are among the commonest and most voluble inhabitants of the valley, and seem even commoner and more talkative than they really are because they are so incessantly on the move.

An alder flycatcher is calling as I go up the first hill (he, too, is very common and very free with his voice, although, unlike siskin and crossbill, he knows where he belongs, and is to be found there, and nowhere else), and when I reach the plateau a sapsucker alights near the foot of a telegraph post just before me; a bird in Quakerish drab, with no trace of red upon either crown or throat. He (or she) is only two or three months old, I suppose, like more than half of all the birds now about us. Not far beyond, as the road runs into light woods, with a swampy tract by a brook on the lower side, I hear a chickadee's voice and look up to see also two Canadian warblers, bits of pure loveliness, the first ones of my present visit. 
A VISIT TO MOUNT AGASSIZ 231

I talk to them, and one, his curiosity responsive to mine, comes near to listen. The Canadian warbler, I have long noticed, has the bump of inquisitiveness exceptionally well developed.

So I go on - a few rods of progress and a few minutes' halt. If there are no birds to look at, there are always flowers, leaves, and berries : goldthread leaves, the prettiest of the pretty - it is a joy to praise them ; and dwarf cornel berries, gorgeous rosettes; and long-stemmed mountain-holly berries, of a color indescribable, fairly beyond praising; and bear-plums, the deep-blue berries of the clintonia. And while the eye feasts upon color the ear feasts upon music: a distant brook babbling downhill among stones, and a breath of air whispering in a thousand treetops; noises that are really a superior kind of silence, speaking of deeper and better things than our human speech has words for. Quietness, peace, contentment, we say; but such vocables, good as they are, are but poor renderings of this natural chorus of barely audible sounds. If you are still enough to hear it - inwardly still 
enough - as may once in a long while happen, you feel things that tongue of man never uttered. Life itself is less sweet. Now and then, as I listen, I seem to hear a voice saying, "Blessed are the dead." I foretaste a something better than this separate, contracted, individual state of being which we call life, and to which in ordinary rnoods we cling so fondly. To drop back into the Universal, to lose life in order to find it, this would be heaven; and for the moment, with this musical woodsy silence in my ears, I am almost there. Yet it must be that I express myself awkwardly, for I am never so much a lover of earth as at such a moment. Life is good. I feel it so now. Fair are the white birch stems; fair are the gray-green poplars. This is my third day, and my spirit is getting in tune.

In the white-pine grove, where a few small birds are stirring noiselessly among the upper branches, my attention is taken by clusters of the ghostly, colorless plant which men know as the Indian pipe (its real name, of necessity, is quite beyond human ken); the flowers, every head bowed, 
just breaking through a bed of last year's needles, while a bumblebee, a capable economic botanist, visits them one by one. Then, as I emerge from the grove on its sunny edge, I catch a sudden pungent odor of balsam. It rises from the dry leaves, the sunlight having somehow set it free. In the shade of the wood nothing of the kind was perceptible. The fact strikes me curiously as one that I have often been half consciously aware of, but now for the first time really notice. On the instant I am taken far back. It is a July noon; I am trudging homeward, and in my proud boyish hand is a basket of shining black huckleberries carefully rounded over. The sense of smell is naturally a sentimentalist; or perhaps the olfactory nerves have some occult connection with the seat of memory.

Here is one of my favorite spots: a level grassy field, with a ruined house and barn behind me, between the road and a swampy patch, and in front "all the mountains," from Moosilauke to Adams. How many times I have stopped here to admire them ! I look at them now, and then fall to watch- 
ing the bluebirds and the barn swallows, that are here at home. A Boston lady holds the legal title to the property (be it said in her honor that she bought it to save the pine wood from destruction), but the birds are its actual owners. Six bluebirds sit in a row on the wire, while the swallows go twittering over the field. Once I fancy that I hear the sharp call of a horned lark; but the note is not repeated, and though I beat the grass over I discover nothing. ${ }^{1}$

Beyond this level clearing the road winds to the left and begins its climb to the height of land, whence it pitches down into Bethlehem village. Every stage of the course is familiar. Here a pileated woodpecker once came out of the woods and disported himself about the trunk of an apple tree for my delectation - mine and a friend's who walked with me; here a hare sat quiet till I was close upon him, and then scampered across

1 Four days afterward (August 9) I found larks of the present season in the Landaff Valley, where I had watched their parents with so much pleasure in May, as I have described in a previous chapter. These August birds were feeding upon oats in the road, like so many English sparrows. 


\section{A VISIT TO MOUNT AGASSIZ 235}

the field with flying jumps ; here is a backward valley prospect that I never can have enough of; and here, just over the wall, I once surprised myself by finding a bunch of yellow lady's-slippers. All this, and much else, I now live over again. So advantageous is it to walk in one's own steps. Many times as I have come this way, I have never come in fairer weather.

And what is this? It looks like a haying-bee. Eight horses and two yokes of oxen, with several empty "hay-riggings" and as many buggies, stand in confused order beside the road, and over the wall men are mowing, spreading, and turning. It is some widow's grass field, I imagine, and her loyal neighbors have assembled to harvest the crop. Human nature is not so bad, after all. So I am saying, with the inexpensive charity natural to a sentimental traveler, when I find myself near a group of younger men who are bantering one of their number ( $\mathrm{I}$ am behind a bushy screen), mixing their talk plentifully with oaths; such a vulgar, stupid, witless repetition of sacred names - without one saving touch 
of originality or picturesqueness - as our honest, thoroughbred, rustic New Englander may challenge the world to equal. These can be no workers for charity, I conclude; and when I inquire of a man who overtakes me on the road (with an invitation to ride), he says: "Oh, no, that is Mr. Blank's farm, and those are all his hired men. $\mathrm{He}$ is about the richest man in Bethlehem." So my pretty idyl vanishes in smoke; the smoke, I am tempted to say, of burning brimstone. I have one consolation, such as it is : the men are Bethlehemites, not Franconians, though I am not so certain that a swearing match between the two towns would prove altogether one-sided. It is nothing new, of course, that beautiful scenery does not always refine those who live near it. It works to that end, within its measure, I am bound to believe, for those who see it; but "there's the rub."

Whether men see it or not, the landscape takes no heed. There it stretches as I turn to look, spaces of level green valley, with mountains and hills round about - mountains and valleys each made perfect by the 
other. I sit down once more in a favorable spot, where every line of the picture falls true, and drink my fill of its loveliness, while a hermit thrush out of the hill woods yonder blesses my ears with music. I have Emerson's wish — " health and a day."

At high noon, as I had planned, I came to the top of the mountain. The observatory was full of chattering tourists, while three individuals of the same genus stood on the rocks below, two men and a woman, the men taking turns in the use - or abuse of a horn, with which they were trying to rouse the echo (a really good one, as I could testify) from Mount Cleveland and the higher peaks beyond. Their attempts were mostly failures. Either the breath wandered about uneasily inside the brazen tube, moaning like a soul in pain - abortive mutterings, but no "toot" — or, if a blast now and then came forth, it was of so low a pitch that the mountains, whose vocal register, it appears, is rather tenor than bass, were unable to return it effectively. "I can't get it high enough," one of the men said. But they had large endowments of perseverance 
- a virtue that runs often to pernicious excess - and seemingly would never have given over their efforts, only that a gentleman's voice from the observatory finally called out, in a tone of long-suffering politeness, "Won't you please let up on that horn, just for a little while?" The hornblowers, not to be outdone in civility, answered at once with a good-natured affirmative, and a heavenly silence, a silence that might be felt, descended upon our ears. Neither blower nor pleader will ever know how heartily he was thanked by a man who lay upon the rocks a little distance below the summit, looking down into the Franconia Valley.

The scene is of exquisite beauty; beauty, moreover, of a kind that I especially love; but for the first half-hour I looked without seeing. It is always so with me in such places, I cannot tell why. Formerly I laid my disability to the fact that the eye had first to satisfy its natural curiosity concerning the details of a strange landscape; its instinctive desire to orient itself by attention to topographical particulars ; and no doubt 
considerations of this nature may be supposed to enter more or less into the problem. But Mount Agassiz offered me nothing to be puzzled over; I felt no need of orientation nor any stirrings of inquisitiveness. On my left was the Mount Washington range, in front were Lafayette and Moosilauke, with the valley intervening, and on the right, haze-covered to-day, rose peak after peak of the Green Mountains. These things I knew beforehand. I had not come to this Pisgah-top to study a lesson in geography, but to enjoy the sight of my eyes.

Still I must practice patience. Timeindispensable Time - is a servant that cannot be hurried, nor can his share of any work be done by the cleverest substitute. "Beautiful!" I said, and felt the word; but the beauty did not come home to the spirit, filling and satisfying it. I wonder at people who scramble to such a peak, stare about them for a quarter of an hour, and run down again contented. Either the plate is preternaturally sensitive, or the picture cannot have been taken.

For myself, I have learned to wait; and 
so I did now. A few birds flitted about the summit: two or three snowbirds, to whom the unusual presence of a man was plainly a trouble ("Why can't he stay up in the observatory, like the rest of his kind?"); a myrtle warbler, chirping softly as he passed; a white-throat, whistling now and then from somewhere down the cliffs; an alder flycatcher, calling quay-queer (a surprising place this dry mountain-top seemed for a lover of swampy thickets); an occasional barn swallow or chimney swift, shooting to and fro under the sky; and once a sparrow hawk, welcome for his rarity, sailing away from me down the valley, showing a rusty tail.

By and by, seeing that the crowd had gone, I clambered up the rocks, eating blueberries by the way, and mounted the stairs to the observatory, where the keeper of the place was talking with two men (a musician and a commercial traveler, if my practice as an "observer" counted for anything), who had lingered to survey the panorama. The conversation turned upon the usual topics, especially the Mount Washington 


\section{A VISIT TO MOUNT AGASSIZ 241}

Railway. Four or five trains were descending the track, one close behind the other, and it became a matter of absorbing interest to make them out through the small telescope and a field glass. Why be at the trouble to climb so high, at the cost of so much wind, unless you do your best to take in whatever is visible? "Yes, I can see one - two - three - Oh, yes, there's the fourth, just leaving the summit." So the talk ran on, with minor variations which may easily be imagined. One important question related to the name of a certain small sheet of water; another to a road that curved invitingly over a grassy hilltop; another to the exact whereabouts of a rich man's fine estate (questions about rich men are always pertinent), the red roofs of which could be found by searching for them.

I took my full share of the discussion, but half an hour of it sufficed, and I went back again to commune with myself upon the rocks. The sunshine was warm, but the breeze tempered it till I found it good. And the familiar scene was lovelier than ever, I began to think. Here at my feet 
stood the little house, down upon which I had looked with such rememberable pleasure on my first visit to Agassiz, I know not how many years ago. Then a man was cutting wood before the door. Now there is nobody to be seen; but the place must still be inhabited, for I hear the tinkle of a cowbell somewhere in the woods, and a horse is pasturing nearer by. Only three or four other houses are in sight - not reckoning the big hotel and a few far-away roofs in Franconia - and very inviting they look, neatly painted, with smooth, level fields about them. It is my own elevation that levels the fields, I am quite aware (when I stop to think of it), as it is distance that softens the contours of the mountains, and the lapse of time that smooths the rough places out of past years; but for the hour I take things as the eye sees them. We come to these visionary altitudes, not to look at realities but at pictures. Distance is a famous hand with the brush. To omit details and to fill the canvas with atmosphere, these are the secrets of his art. A comfortable thing it is to lie here at my ease and 
yield myself to the great painter's enchantments.

My eye wanders over the landscape, but not uneasily; nay, it can hardly be said to wander at all; it rests here and there, not trying to see, but seeing. Now it is upon the road, spaces of which show at intervals, while I imagine the rest - a sentimental journey; now upon a far-off grassy clearing among woods (Mears's or Chase's), homely enough, and lonely enough - and familiar enough — to fit the mood of the hour; now upon the distant level reaches of the Landaff Valley. But the beauty of the scene is not so much in this or that as in all together. I say now, as I said twenty years ago, "This is the kind of prospect for me:" a broken valley, fields and woods intermingled, with mountains circumscribing it all; a splendid panorama seen from above, but not from too far above; from a hill, that is to say, rather than from a mountain.

An hour of this luxury and I return to the tower, where the musician and the keeper are still in conference. The keeper, especially, is a man much after my own 


\section{FOOTING IT IN FRANCONIA}

mind. He knows the people who live in the three houses below us, and speaks of them racily, yet in a tone of brotherly kindness. I call his attention to two women whom I have descried in the nearest pasture, a bushy place, yellow with goldenrod and pointed with young larches and firs. They wear men's wide-brimmed straw hats (a black-and-tan collie is with them), and one carries a broad tin dish, which she holds in one hand, while she picks berries with the other. Pretty awkward business, an old berry-picker thinks.

Yes, the keeper of the tower says, they are Mrs. _ _ and Miss__ ; one lives in the first house, the other in the second. Now they are leaving the pasture, stopping once in a while to strip an uncommonly inviting bush (so I interpret their movements), and we follow them with our eyes. The older one, a portly body, walks halfway across a broad field with her companion, seeing her so far homeward, - and perhaps finishing a savory dish of gossip, - and then returns to her own house, still accompanied by the dog. Scarcity of neighbors conduces to neighborliness. 
The men who live in such houses, the keeper tells me, are very wide-awake and well informed, reading their weekly newspaper with thoroughness, and always ready for rational talk on current topics. They are not rich, of course, in the down-country sense of the word, and see very little money, subsisting mainly upon the produce of the farm ; a matter of twenty-five dollars a year may cover all their expenditures; but they are better fed, and really live in more comfort, than a great part of the folks who live in cities. I am glad to believe it; and I like the man's way of standing by his neighbors. In fact, I think highly of him as a person of a good heart and no small discrimination; and therefore $I$ am all the gladder when, having left the summit and stopped for a minute in the shade of a tree, I overhear him say to the musician, "That old man enjoys himself; he's a nice old man." "Thank you," say I, not aloud, but with deep inward sincerity; "that's one of the best compliments I've had for many a day." Blessings on this mountain aur, that makes human speech unintention- 
ally audible. An old man that enjoys himself is pretty near to my ideal of respectable senility. "Thank you," I repeat; "that's praise, and faith, I'll print it." And so I will, pleasing myself, let the ungentle reader - if I have one - think what he may. A good name is more to brag of than a million of money.

Yes, I am enjoying myself (why not?), and I loiter down the road with a light heart (an old man should be used to going downhill), pausing by the way to notice a little group - a family party, it is reasonable to guess - of golden-crowned kinglets. One of them, the only one I see fully, has a plain crown, showing neither black stripes nor central orange patch. But for his unmistakable zee-zee-zee, which he is considerate enough to utter while I am looking at him, he might be taken for a ruby-crown. So the lover of beauty and the hobbyist descend the hill together, keeping step like inseparable friends. And so may it be to the end of the chapter. 


\section{INDEX}





\section{INDEX}

ADDER'S-MOUTH, 149.

Fleas, 32.

Arbutus, trailing, 57, 91, 133.

Aster Lindleyanus, 5, 181.

Azalea, Lapland, 140.

Beech-fern, 146.

Blueberries, alpine, 24.

Bluebird, 123, 125, 209, 210, 234.

Bobolink, 97, 110, 117, 213.

Butterflies, 10, 28, 36, 123, 145, 172.

Catbird, 29, 106, 117, 189, 191.

Cedar-bird, 15, 187.

Cherry, wild red, 79, 130, 148, 211 ; rum, 183.

Chickadee, black - capped, $13,15,16,22,72,83,94$, 170, 191 ; Hudsonian, 15, 53.

Chokeberry, 133.

Chokecherry, yellow, 181.

Cicada, 54 .

Clintonia, 164, 231.

Coltsfoot, 67.

Cornel, dwarf, 57, 122, 133, $150,163,231$.

Creeper, brown, 129, 138.

Crossbill, red, 19, 194, 228; white-winged, 19.

Crow, $11,97,210$.

Cuckoo, black-billed, 145.

Finch, pine, 126, 144, 170,228; purple, 117 .

Flowers, alpine, 140.

Flycatcher, alder, 105, 125, $148,214,230,240$; crested, $99,125,210,214$; least, $212,213,214$; olive-sided, 101, 105, 130, 169, 212, 214; yellow-bellied, 101, 215.

Fox, 58.

Goldfinch, 72, 172, 189, 191, 211.

Goldthread, 57, 83, 133, 150, 231.

Grosbeak, rose-breasted, 86, $117,127$.

Grouse, 27, 101, 192, 205, 210, 211.

Hardhack, 155.

Hawk, sparrow, 240.

Hobble-bush, 13, 130.

Houstonia, 133.

Humming-bird, 160, 205.

Hyla, 192.

Indigo-bird, 159.

Kinglet, golden - crowned, $138,192,246$; rubycrowned, 29, 66, 72, 192 .

Kingfisher, 16.

Lady's-slipper, pink, 108, 133 ; yellow, 111, 235.

Lark, meadow, 115 ; prairie horned, 162, 166, 195, 217, 234.

Lonesome Lake, 11. 
Martin, purple, 117.

Maryland yellow-throat, 72, $125,145,189$.

Merganser, 221.

Mountain ash, 17.

Mountain holly, 163, 231.

Nuthatch, red-breasted, 17, 121, 194; white-breasted, $189,213,216$.

Oriole, 117.

Oven-bird, 125, 143, 216.

Owl, barred, 22.

Phœbe, 191, 209.

Raspberry, 151, 162

Rhodora, 85, 133.

Robin, 13, 22, 74, 117, 170, 189, 191.

Salix balsamifera, $6,41,85$, 155.

Sandpiper, solitary, 89,115 , 170.

Sandwort, Greenland, 25.

Sapsucker, 68, 148, 183, 184, $189,215,230$.

Shadbush, 80, 83, 91, 133, 211.

Shadbush, few-flowered, 91, 133.

Siskin, pine, 126, 144, 170, 228.

Snowbird, 14, 15, 63, 240.

Sparrow, chipping, 77 ; English, 118; field, 77, 116, $117,159,189$; fox, 57 ; Lincoln's, $68,74,77$; savanna, 78 ; song, 72,74 , $77,117,123,159,170,189$, 191, 210 ; swamp, 74, 172 ; vesper, $8,44,51,116$, $117,123,160$, 191 ; whitecrowned, $74,77,114,194$; white-throated, $13,15,25$, $57,66,74,83,93,130,148$, 160, 170, 189, 191.
Spiders, 31.

Spring-beauty, 88, 89.

Swallow, bank, 117, barn, $97,117,118,152,159,234$, 240 ; cliff, 117 ; tree, 117.

Swift, 134, 240.

Tanager, 72, 101, 117, 126.

Thorn-bush, 180.

Thrush, gray-cheeked, 117 ; hermit, 14, 21, 29, 30, 39, $80,113,115,117,148,159$, 165, 191, 237 ; olive-backed (Swainson's), 14, 21, 22, $101,117,144,189,193$; water, 105; Wilson's (veery), 101, 110, 115, 117 ; wood, 112, 117, 126, 127.

Toad, 131.

Trillium, painted, 83, 133.

Violet, dog - tooth, 89 ; round-leaved, $88,89,130$; Selkirk's, 122, 135.

Vireo, Philadelphia, 189, 190 ; red-eyed, 18, 72, 116, $144,159,170,210$; solitary, $8,66,68,72,117,148$, 189 , 191; warbling, 120; yellow-throated, $115,214$.

Warbler, bay-breasted, 72, $73,87,94$; Blackburnian, $86,87,94,135$; black-andwhite, 10t; blackpoll, 72, 142 ; black-throated blue, 126 ; black-throated green, 72, 189; blue yellowbacked, 127, 216 ; Canada, 101, 230; Cape May, 94, $102,103,106,107,111,198$, 217 ; chestnut-sided, 72, 73, 170; magnolia, 101, 127, 144; mourning, 112, 128 ; myrtle, 68, 72, 143, 144, 189, 211, 240 ; Nashville, $127,189,213$; Tennessee, 41, 92, 101, 102, 
103, 105 ; Wilson's blackcap, 114.

Woodchuck, $61,86,96$.

Wood pewee, 169, 214.

Woodpecker, arctic three- Wren, winter, 10, 57, 72, 90, toed, 14; downy, 68; 117. golden-winged, $16,68,72$; hairy, 41 ; pileated, 45,99 , $156,183,193,234$.

Wood sorrel, 167. 
Che Tituergide pregig

Electrotyped and printed by H.O. Houghton \& Co: Cambridge, Mass., U.S. A. 




